NATIONAL LABORATORY

\title{
Heavy and Overweight Vehicle Brake Testing: Combination Five-Axle Tractor- Flatbed Final Report
}

\section{Oct 2013}

Prepared by

Mary Beth Lascurain

Gary Capps

Oscar Franzese

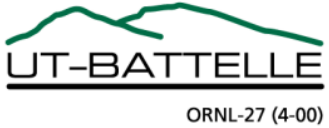




\section{DOCUMENT AVAILABILITY}

Reports produced after January 1, 1996, are generally available free via the U.S. Department of Energy (DOE) Information Bridge.

Web site http://www.osti.gov/bridge

Reports produced before January 1,1996, may be purchased by members of the public from the following source.

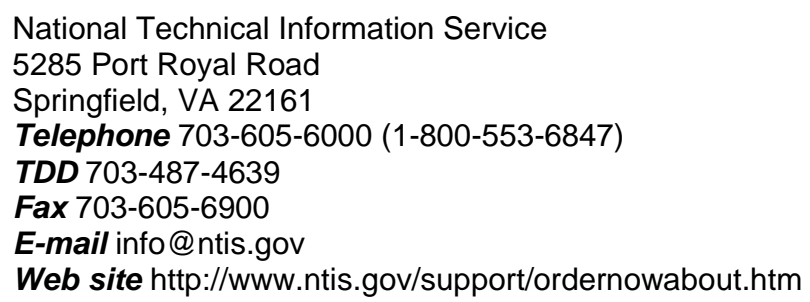

Reports are available to DOE employees, DOE contractors, Energy Technology Data Exchange (ETDE) representatives, and International Nuclear Information System (INIS) representatives from the following source.

Office of Scientific and Technical Information

P.O. Box 62

Oak Ridge, TN 37831

Telephone 865-576-8401

Fax 865-576-5728

E-mail reports@osti.gov

Web site http://www.osti.gov/contact.html

This report was prepared as an account of work sponsored by an agency of the United States Government. Neither the United States Government nor any agency thereof, nor any of their employees, makes any warranty, express or implied, or assumes any legal liability or responsibility for the accuracy, completeness, or usefulness of any information, apparatus, product, or process disclosed, or represents that its use would not infringe privately owned rights. Reference herein to any specific commercial product, process, or service by trade name, trademark, manufacturer, or otherwise, does not necessarily constitute or imply its endorsement, recommendation, or favoring by the United States Government or any agency thereof. The views and opinions of authors expressed herein do not necessarily state or reflect those of the United States Government or any agency thereof. 
Energy and Transportation Science Division

HEAVY AND OVERWEIGHT VEHICLE BRAKE TESTING: COMBINATION FIVE-AXLE TRACTOR-FLATBED FINAL REPORT

\author{
Mary Beth Lascurain \\ Gary Capps \\ Oscar Franzese
}

Date Published: October 2013

Prepared by

OAK RIDGE NATIONAL LABORATORY

Oak Ridge, Tennessee 37831-6283

managed by

UT-BATTELLE, LLC

for the

U.S. DEPARTMENT OF ENERGY

under contract DE-AC05-00OR22725 



\section{CONTENTS}

Page

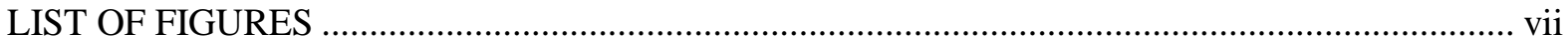

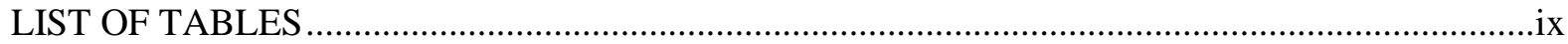

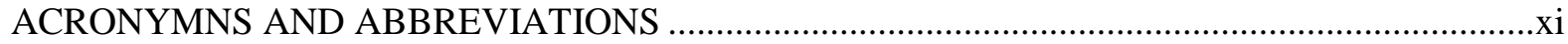

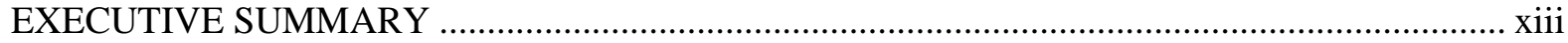

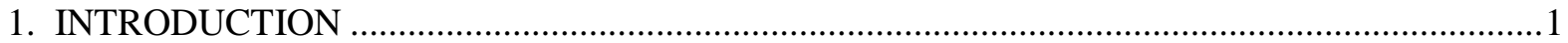

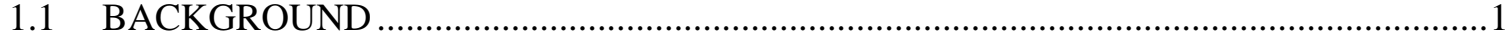

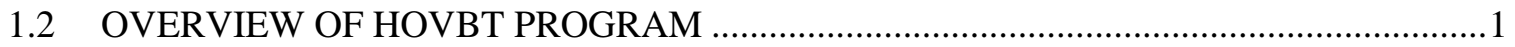

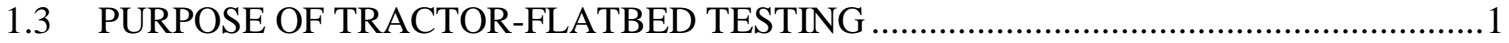

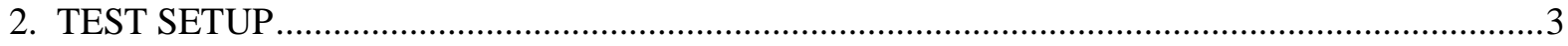

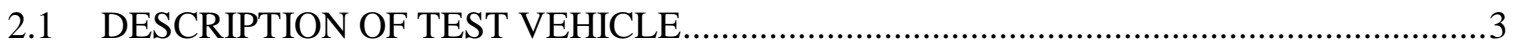

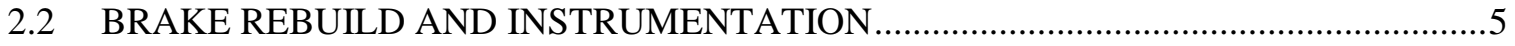

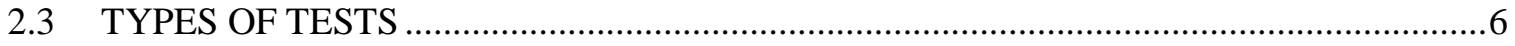

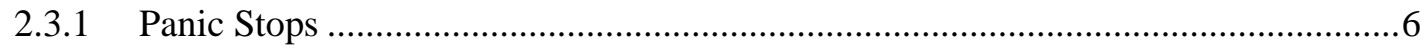

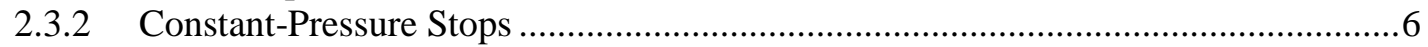

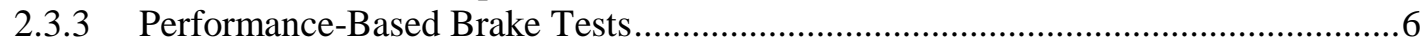

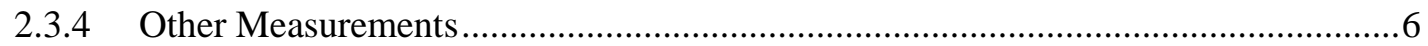

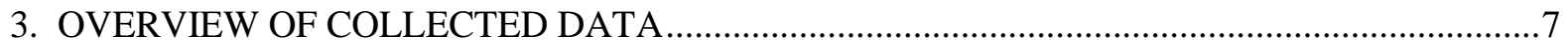

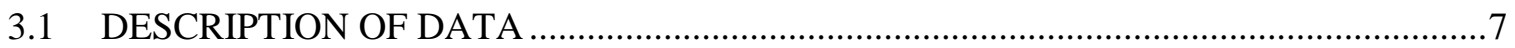

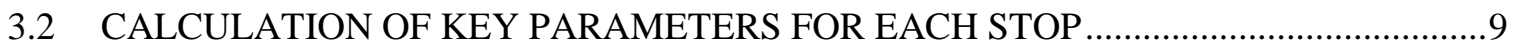

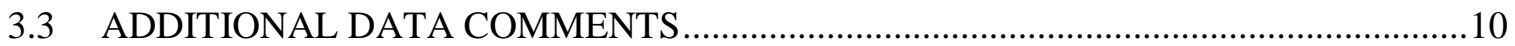

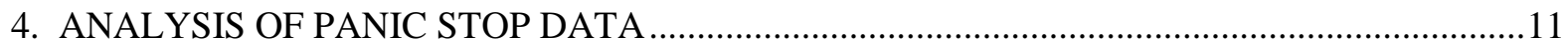

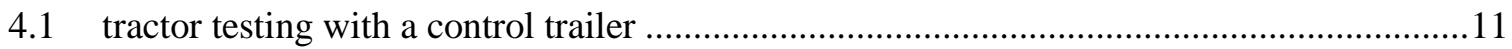

4.2 OVERVIEW OF RESULTS FOR 20-MPH PANIC STOPS .......................................... 11

4.3 OVERVIEW OF RESULTS FOR 60-MPH PANIC STOPS ..............................................12

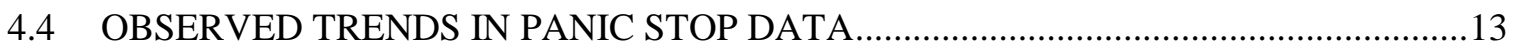

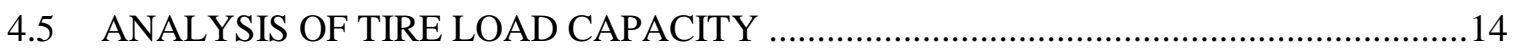

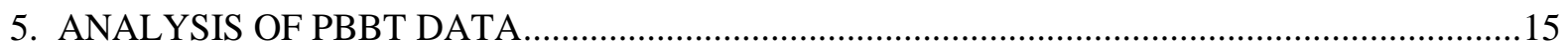

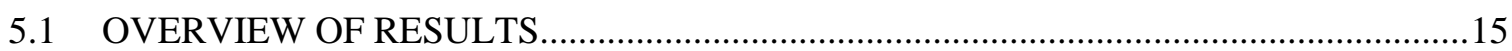

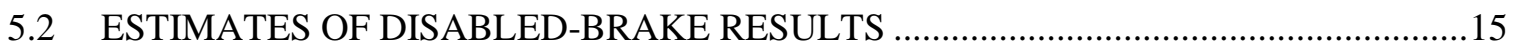

5.3 EFFECT OF LOAD AND DEFECT POSITION ON BRAKE EFFICIENCY ..................16

5.4 COMPARISON OF SCALE-AND PBBT-REPORTED WEIGHTS ................................... 17

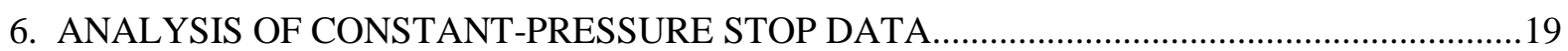

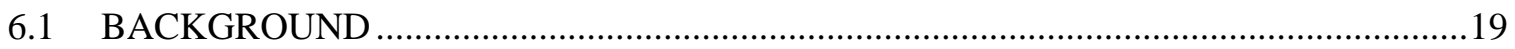

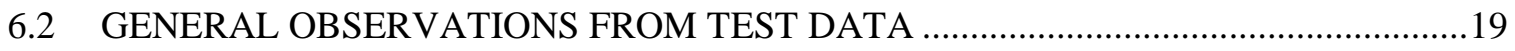

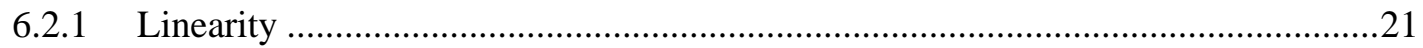

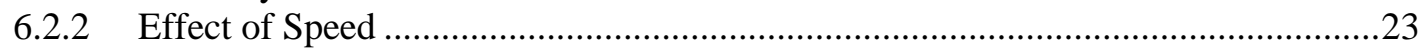

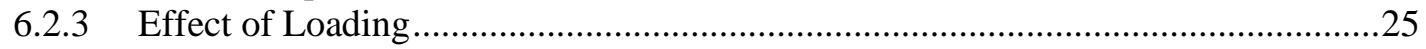

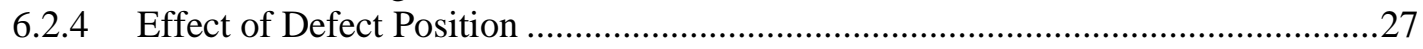

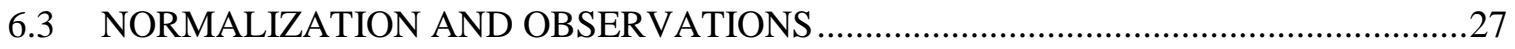

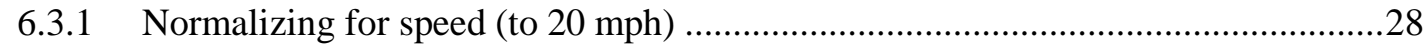

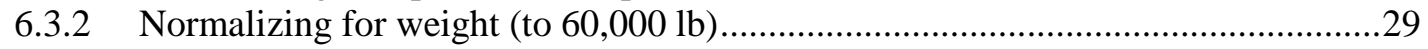

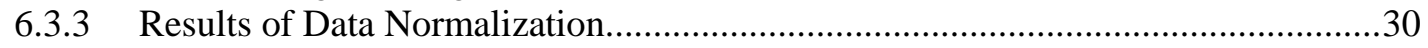

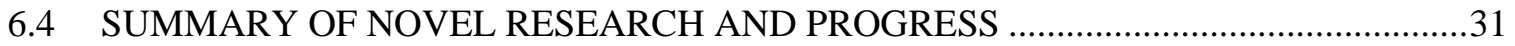

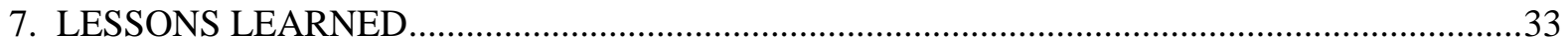

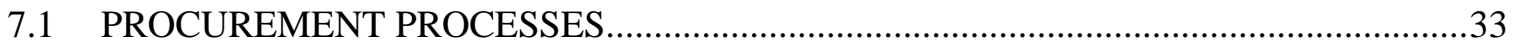

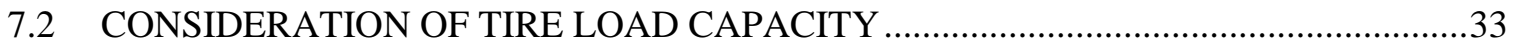


7.3 TIMING OF ANALYSIS COMPONENT ....

8. FUTURE DIRECTIONS .

APPENDIX A: SUMMARY OF STOPPING TEST RESULTS

APPENDIX B: BRAKE STROKE MEASUREMENT LOG

. .51

APPENDIX C: PBBT RESULTS. 


\section{LIST OF FIGURES}

\section{Page}

Figure 1. Test vehicle in 80,000-lb GVW configuration. .................................................................

Figure 2. Time history plot of data from a constant-pressure stop. .................................................

Figure 3. Comparison of stopping distances for 20-mph panic stops............................................. 12

Figure 4. Comparison of stopping distances for 60-mph panic stops ..............................................13

Figure 5. Comparison of predicted and actual PBBT scores for disabled brake scenarios.................16

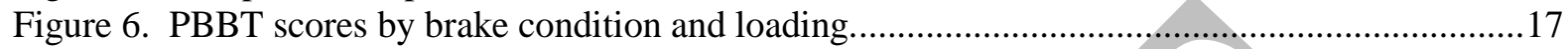

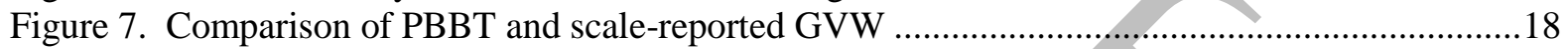

Figure 8. Pressure-deceleration curves for 60,000 lb GVW load. .................................................20

Figure 9. Pressure-deceleration curves for 80,000-lb GVW load...................................................21

Figure 10. Pressure-decelaration curves for $60,000-\mathrm{lb}$ GVW loading condition (15-45 psi).............22

Figure 11. Pressure-deceleration curves for 80,000-lb GVW loading condition (15-45 psi)............23

Figure 12. Comparison of sample speed profiles for 20- and 60-mph constant-pressure stops............24

Figure 13. Comparison of sample deceleration profile for 20- and 60-mph constant-pressure stops...25

Figure 14. Pressure-deceleration curves by load and brake condition for $20 \mathrm{mph}$..........................26

Figure 15. Pressure-deceleration curves by load and brake condition for $60 \mathrm{mph}$........................27

Figure 16. Original pressure-deceleration data before normalization...........................................28

Figure 17. Full-function pressure-deceleration data normalized to 20-mph initial speed...................29

Figure 18. Full-function pressure-deceleration data normalized to $60,000-1 b$ GVW load....................30

Figure 19. All pressure-deceleration data following normalization..................................................31 


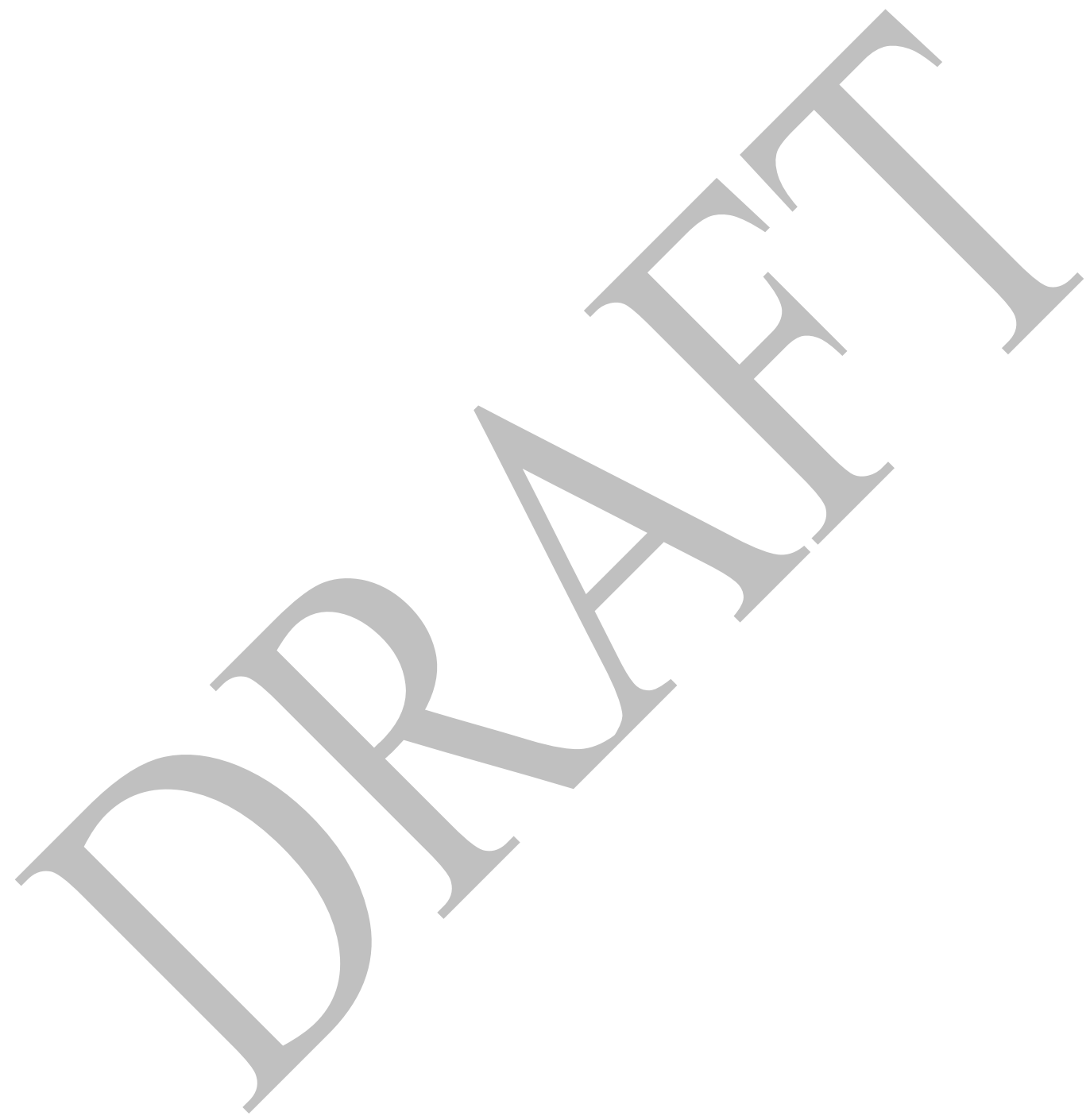




\section{LIST OF TABLES}

\section{Page}

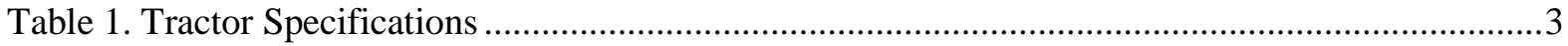

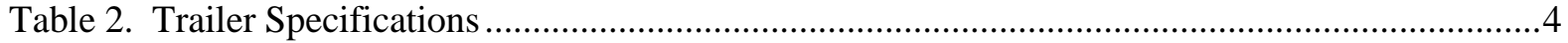

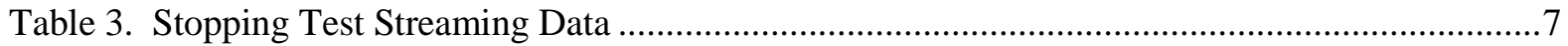

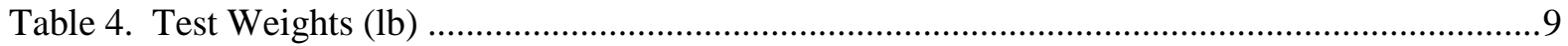

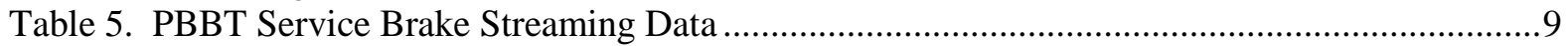

Table 6. Parameters Calculated for Each Stopping Test .............................................................10

Table 7. Average Corrected Stopping Distance for 20-mph Panic Stops ............................................12

Table 8. Average Corrected Stopping Distances for 60-mph Panic Stops...........................................13

Table 9. Tire Load Capacity for Loading Conditions ........................................................................ 14

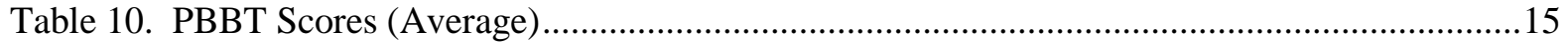

Table 11. Comparison of Actual and Estimated PBBT Scores ......................................................... 15

Table C1. PBBT Scores - Fully Functioning Brakes, Before Test Set..............................................61

Table C2. PBBT Scores - Fully Functioning Brakes, After Test Set ...............................................62

Table C3. PBBT Scores - Disabled Front Drive Axle Brakes, Before Test Set.................................63

Table C4. PBBT Scores - Disabled Front Drive Axle Brakes, After Test Set ..................................64

Table C5. PBBT Scores - Disabled Rear Trailer Axle Brakes, Before Test Set ................................65

Table C6. PBBT Scores - Disabled Rear Trailer Axle Brakes, After Test Set ..................................66 


\section{ACRONYMNS AND ABBREVIATIONS}

$\begin{array}{ll}\text { Term } & \text { Definition } \\ \text { CFR } & \text { Code of Federal Regulations } \\ \text { CMV } & \text { Commercial Motor Vehicle } \\ \text { FHWA } & \text { Federal Highway Administration } \\ \text { FMCSA } & \text { Federal Motor Carrier Safety Administration } \\ \text { FMCSR } & \text { Federal Motor Carrier Safety Regulation } \\ \mathrm{ft} & \text { Feet } \\ \mathrm{ft} / \mathrm{s}^{2} & \text { Feet per second squared } \\ \text { FMVSS } & \text { Federal Motor Vehicle Safety Standards } \\ \text { GPS } & \text { Global Positioning System } \\ \text { GVW } & \text { Gross Vehicle Weight } \\ \text { GVWR } & \text { Gross Vehicle Weight Rating } \\ \text { HOVBT } & \text { Heavy and Overweight Vehicle Brake Testing } \\ \text { Hz } & \text { Hertz } \\ \text { lb } & \text { Pounds } \\ \text { mph } & \text { Miles per hour } \\ \text { MTDC } & \text { Medium Truck Duty Cycle } \\ \text { ORNL } & \text { Oak Ridge National Laboratory } \\ \text { PBBT } & \text { Performance-Based Brake Tester } \\ \text { psi } & \text { Pounds per square inch } \\ \text { RSD } & \text { Reduced Stopping Distance } \\ \text { sec } & \text { Seconds }\end{array}$




\section{EXECUTIVE SUMMARY}

The Federal Motor Carrier Safety Administration, in coordination with the Federal Highway Administration, sponsored the Heavy and Overweight Vehicle Brake Testing (HOVBT) program in order to provide information about the effect of gross vehicle weight (GVW) on braking performance. Because the Federal Motor Carrier Safety Regulations limit the number of braking system defects that may exist for a vehicle to be allowed to operate on the roadways, the examination of the effect of brake defects on brake performance for increased loads is also relevant. The HOVBT program seeks to provide relevant information to policy makers responsible for establishing load limits, beginning with providing test data for a combination tractor/trailer.

This testing was conducted on a five-axle combination vehicle with tractor brakes meeting the Reduced Stopping Distance requirement rulemaking. This report provides a summary of the testing activities, the results of various analyses of the data, and recommendations for future research. Following a complete brake rebuild, instrumentation, and brake burnish, stopping tests were performed from 20 and $40 \mathrm{mph}$ with various brake application pressures (15 psi, $25 \mathrm{psi}, 35 \mathrm{psi}, 45 \mathrm{psi}, 55 \mathrm{psi}$, and full system pressure). These tests were conducted for various brake conditions at the following GVWs: $60,000,80,000,91,000$, $97,000,106,000$, and 116,000 lb. The 80,000-lb GVWs included both balanced and unbalanced loads. The condition of the braking system was also varied. To introduce these defects, brakes (none, forward drive axle, or rear trailer axle) were made inoperative. In addition to the stopping tests, performancebased brake tests were conducted for the various loading and brake conditions.

Analysis of the stopping test data showed the stopping distance to increase with load (as expected) and also showed that more braking force was generated by the drive axle brakes than the trailer axle brakes. The constant-pressure stopping test data revealed a linear relationship between brake application pressure and was used to develop an algorithm to normalize stopping data for weight and initial speed.

This research also revealed three lessons learned which can be used in future research of a similar nature, addressing areas of procurement, component loading, and the timing of the analysis effort in project planning. This research also shed light on areas in which future research should focus, including further data collection to develop and test an on-board brake assessment algorithm and similar tests of vehicles with other body types. 


\section{INTRODUCTION}

\subsection{BACKGROUND}

Commercial trucks normally travel at or below the maximum weight allowed by the Federal Highway Administration (FHWA) Bridge Formula on the interstate highways. Many states allow commercial trucks to operate on state roads and highways at weights significantly higher than that allowed under the FHWA Bridge Formula. The Federal Motor Carrier Safety Administration (FMCSA) and FHWA are interested in gathering real-world brake performance and stopping distance test data on vehicles representative of current in-use commercial motor vehicles that are operating at Bridge Formula weights, weights that are grandfathered under state commercial truck weight provisions on non-interstate highways, and permitted weights.

\subsection{OVERVIEW OF HOVBT PROGRAM}

The Heavy and Overweight Vehicle Brake Testing (HOVBT) program was designed to provide information about the effect of gross vehicle weight (GVW) on braking performance. Because the Federal Motor Carrier Safety Regulations (FMCSRs) limit the number of braking system defects that may exist for a vehicle to be allowed to operate on the roadways, the examination of the effect of brake defects on brake performance for increased loads is also relevant. The HOVBT program seeks to provide relevant information to policy makers responsible for establishing load limits, beginning with providing test data for a combination tractor/trailer. It is expected that future efforts will involve straight truck testing and may be expanded to other body types.

\subsection{PURPOSE OF TRACTOR-FLATBED TESTING}

Oak Ridge National Laboratory (ORNL) gathered the required stopping distance data via subcontract to Link Commercial Vehicle Testing (East Liberty, Ohio) and analyzed the data to provide background information regarding the braking capability of air-braked commercial combination vehicles operating at maximum weight allowed by FHWA Bridge Formula and in heavy weight conditions under various levels of brake performance. This testing was conducted on a vehicle with larger tractor brakes meeting the Reduced Stopping Distance (RSD) requirement rulemaking reflected in Federal Motor Vehicle Safety Standards (FMVSS)-121 (49 CFR Part 571). This report provides a summary of the testing activities, the results of various analyses of the data, and recommendations for future research. 


\section{TEST SETUP}

This section provides information regarding the test vehicle and various tests performed as part of the HOVBT effort.

\subsection{DESCRIPTION OF TEST VEHICLE}

The test vehicle was a 2013 model year Volvo VNL tractor with a flatbed trailer. The use of the flatbed allowed for more efficient change of test loads than would be available for a box-type trailer. Because all tests involving vehicle movement were performed along a straight-line path, the trailer type was not expected to be a significant factor in braking performance. The specifications for the tractor and trailer are shown in Table 1 and Table 2, respectively. The combination tractor/trailer is shown in the 80,000-lb GVW balanced load configuration in Figure 1.

Table 1. Tractor Specifications

\begin{tabular}{|c|c|c|c|}
\hline \multicolumn{4}{|c|}{ General Information } \\
\hline Manufacturer & \multicolumn{3}{|c|}{ Volvo } \\
\hline Type & \multicolumn{3}{|c|}{$6 \times 4$ Tractor } \\
\hline Model Number & \multicolumn{3}{|c|}{2013 VNL64T 670} \\
\hline Date of Manufacture & \multicolumn{3}{|c|}{ January 2012} \\
\hline VIN & \multicolumn{3}{|c|}{ 4V4NC9TH8DN567427 } \\
\hline GVWR & \multicolumn{3}{|c|}{$51,200 \mathrm{lb}$} \\
\hline No. of Axles & \multicolumn{3}{|c|}{3} \\
\hline \multicolumn{4}{|c|}{ Axle Information } \\
\hline & Axle 1 & Axle 2 & Axle 3 \\
\hline GAWR & $13.2 \mathrm{k}$ & $19 \mathrm{k}$ & $19 \mathrm{k}$ \\
\hline Suspension Type & Spring & Airbag & Airbag \\
\hline \multicolumn{4}{|c|}{ Brakes } \\
\hline Manufacturer & Meritor & Meritor & Meritor \\
\hline Type & $\mathrm{Q}+\mathrm{S}-\mathrm{Cam}$ & $\mathrm{Q}+\mathrm{S}-\mathrm{Cam}$ & $\mathrm{Q}+\mathrm{S}-\mathrm{Cam}$ \\
\hline Size & $16.5 \times 5$ & $16.5 \times 7$ & $16.5 \times 7$ \\
\hline Lining Code & SOR 1201 & SOR 2001 & SOR 2001 \\
\hline Chamber Make / Size & MGM 24L3 & MGM 3030L3 & MGM 30L3 \\
\hline Slack Make / Size & Meritor 5.5 & Meritor 5.5 & Meritor 5.5 \\
\hline Rotor or Drum Make / Part \# & Gunite 3772 & Gunite 3600A & Gunite $3600 \mathrm{~A}$ \\
\hline ABS & \multicolumn{3}{|c|}{ Bendix 6S4M } \\
\hline \multicolumn{4}{|c|}{ Tires } \\
\hline Manufacturer & Bridgestone & Bridgestone & Bridgestone \\
\hline Tread Name & $\mathrm{R} 280$ & M726EL & M726EL \\
\hline Size & 295/75R22.5 & 295/75R22.5 & $295 / 75 \mathrm{R} 22.5$ \\
\hline Load Range & "H" & "G" & "G" \\
\hline Pressure & $120 \mathrm{psi}$ & $110 \mathrm{psi}$ & $110 \mathrm{psi}$ \\
\hline Max Load per Tire (Config.) & $7160 \mathrm{lb}$ (Single) & $5675 \mathrm{lb}$ (Dual) & $5675 \mathrm{lb}$ (Dual) \\
\hline
\end{tabular}


Table 2. Trailer Specifications

\begin{tabular}{|l|l|}
\hline \multicolumn{2}{|c|}{ General Information } \\
\hline Make / Model & Utility Trailer 48' flatbed \\
\hline GVWR & $80,000 \mathrm{lb}$ \\
\hline Date of Mfg. & Aug-07 \\
\hline Wheelbase & $50 "$ \\
\hline VIN & 1UY FS2454 8A4536 02 FS2CHA \\
\hline Suspension & Spring \\
\hline \multicolumn{2}{|l|}{ Axle 1 } \\
\hline Make / Model & Meritor \\
\hline SN & FRK00335318 PN:TN4671L4516 \\
\hline GAWR & 20,000 lb \\
\hline \multicolumn{2}{|l|}{ Axle 2 } \\
\hline Make / Model & Meritor \\
\hline SN & PN:TN4671L4516 \\
\hline GAWR & 20,000 lb \\
\hline \multicolumn{2}{|l|}{ Brakes } \\
\hline Make / Model & Meritor \\
\hline Type/Size & S-cam 16.5x7 \\
\hline Chambers Make / Size & Haldex T3030 \\
\hline Slacks Make / Size & Haldex ASA 5.5" \\
\hline Lining Edge Code & MA210 FF (4707) \\
\hline (Drum - Rotor) Number / Size & Meritor B5123207002 \\
\hline ABS Manufacturer & Wabco 2S1M \\
\hline \multicolumn{2}{|l|}{ Tires } \\
\hline Make / Model & Bridgestone R280 \\
\hline Size & $295 / 75 R 22.5$ (Load Range H) \\
\hline Static Loaded Radius & $19.1 " ~$ \\
\hline Pressure & 120 psi \\
\hline Max Load per Tire & 6610 lb (Dual) \\
\hline
\end{tabular}




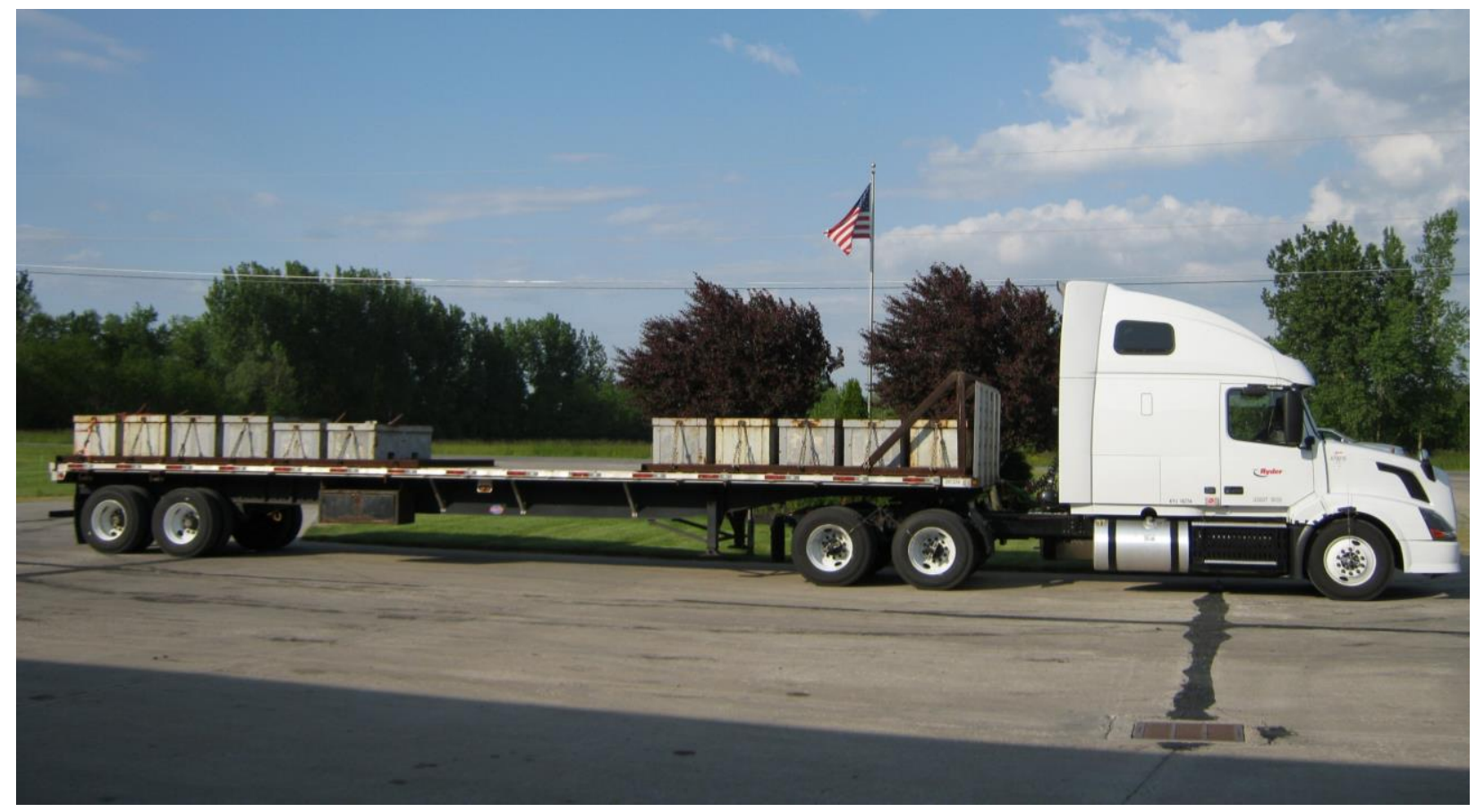

Figure 1. Test vehicle in 80,000-lb GVW configuration.

The test tractor was outfitted with the larger front brakes, complying with the RSD requirements for three-axle tractors with a GVWR of 59,600 lb or less manufactured on or after August 1, 2011. While the braking capacity of this test vehicle is not representative of that of the typical vehicle on the road today, it may be representative of the typical vehicle several years in the future when the majority of similar vehicles comply with the RSD requirement.

\subsection{BRAKE REBUILD AND INSTRUMENTATION}

In preparation for testing, a complete foundation brake rebuild was performed. Linings, drum, anchor pins, anchor pin bushings, brake shoe rollers, and return springs were replaced. Other foundation brake components were found to be in acceptable condition and were not replaced. The tires on the test vehicle were also replaced as the originals showed excessive wear. Prior to testing, a 500-stop burnish was performed on the new brake system in accordance with the FMVSS-121 procedure.

The process of rebuilding and burnishing ensured the effects of loading, brake condition, and brake application pressure on brake performance examined in this study were not compounded by performance degradation introduced by any braking system components that were worn, faulty, or not properly broken in.

In preparation of the various tests performed as part of this research, the test vehicle was instrumented with sensors to collect speed, brake application pressure, and related data such as tire temperature. A complete list of all the signals collected appears in Section 3.1. In addition, a pressure regulator was installed near the treadle valve to allow the operator to provide a precise brake application pressure to the primary and secondary pressure circuits. 


\subsection{TYPES OF TESTS}

The following tests were performed for various brake conditions at the following approximate GVWs: $60,000,80,000,91,000,97,000,106,000$, and 116,000 lb. The 80,000-lb GVWs included both balanced and unbalanced loads. The condition of the braking system was also varied. To introduce these defects, brakes (none, forward drive axle, or rear trailer axle) were made inoperative rather than changing adjustment-not only is this the easiest to quantify (in terms of brake degradation), but it is the worst-case scenario for a brake defect. In all test scenarios, the brakes involved in ABS actuation remained enabled. All stopping tests were performed along a straight-line path.

\subsubsection{Panic Stops}

Panic stops were performed by bringing the test vehicle up to slightly above the target speed (20 or 60 mph) and applying the full braking capacity of the vehicle (full treadle application without the use of a pressure regulator to limit the brake application pressure) until the vehicle came to a complete stop. The procedure followed was that specified for the stopping tests in FMVSS-121, following a straight-line path. This test was performed for all combinations of loading and brake conditions. To provide comparison data, 20- and 60-mph stops were also performed using an unbraked control trailer as specified in FMVSS-121 to bring the GVW up to the required test value.

\subsubsection{Constant-Pressure Stops}

Constant-pressure stops were performed by bringing the test vehicle up to slightly above the target speed ( 20 or $60 \mathrm{mph}$ ) and applying the target constant pressure $(15,25,35,45$, or 55 psi) until the vehicle came to a complete stop. An in-line pressure regulator (with driver override capability, for safety) was used to apply a constant brake system pressure during the stop. These tests were performed for all brake conditions (full, disabled drive, and disabled trailer) for 60,000-lb and 80,000-lb GVWs (75\% and 100\% load capacity respectively).

\subsubsection{Performance-Based Brake Tests}

Performance-based brake tests were performed with an FMCSA-certified Performance-Based Brake Testing (PBBT) machine. In addition to weight and brake application data, wheel-end air pressure information was also obtained for each axle using pressure transducers.

\subsubsection{Other Measurements}

Weigh tickets were also generated for each load configuration. Additionally, brake-stroke measurements were taken periodically throughout the test period. The temperature of the braking components was also monitored throughout testing to ensure the brakes did not overheat (primary lining temperatures remaining below $200^{\circ} \mathrm{F}$ ). 


\section{OVERVIEW OF COLLECTED DATA}

\subsection{DESCRIPTION OF DATA}

For the stopping tests, the signals shown in Table 3 were collected at $100 \mathrm{~Hz}$. The temperatures listed are for the primary linings on the indicated wheel-end. For each run, data was collected beginning 1 second (sec) prior to the application of the brakes and ending $0.5 \mathrm{sec}$ after the vehicle speed decreased to 0.4 mph.

Table 3. Stopping Test Streaming Data

\begin{tabular}{|l|c|}
\hline Parameter & Units \\
\hline Time & $\mathrm{sec}$ \\
\hline Vehicle Speed & $\mathrm{mph}$ \\
\hline Deceleration & $\mathrm{ft} / \mathrm{s}^{2}$ \\
\hline Primary Control Pressure & $\mathrm{psi}$ \\
\hline Left Front Pressure & $\mathrm{psi}$ \\
\hline Right Front Pressure & $\mathrm{psi}$ \\
\hline Left Intermediate (Forward Drive) Pressure & $\mathrm{psi}$ \\
\hline Right Rear Pressure & $\mathrm{psi}$ \\
\hline Spring Brake Pressure & $\mathrm{psi}$ \\
\hline Primary Reservoir Pressure & $\mathrm{psi}$ \\
\hline Secondary Reservoir Pressure & $\mathrm{psi}$ \\
\hline Secondary Control Pressure & $\mathrm{psi}$ \\
\hline Left Forward Trailer Axle Pressure & $\mathrm{psi}$ \\
\hline Right Rear Trailer Axle Pressure & $\mathrm{psi}$ \\
\hline Left Front Wheel Speed & $\mathrm{mph}$ \\
\hline Right Front Wheel Speed & $\mathrm{mph}$ \\
\hline Left Intermediate (Forward Drive) Wheel Speed & $\mathrm{mph}$ \\
\hline Right Intermediate (Forward Drive) Wheel Speed & $\mathrm{mph}$ \\
\hline Left Rear Wheel Speed & ${ }^{\mathrm{mph}}$ \\
\hline Right Rear Wheel Speed & $\mathrm{mph}$ \\
\hline Ambient Temperature & ${ }^{\circ} \mathrm{F}$ \\
\hline Left Front Temperature & ${ }^{\circ} \mathrm{F}$ \\
\hline Right Front Temperature & ${ }^{\circ} \mathrm{F}$ \\
\hline Left Intermediate (Forward Drive) Temperature & ${ }^{\circ} \mathrm{F}$ \\
\hline Right Intermediate (Forward Drive) Temperature & ${ }^{\circ} \mathrm{F}$ \\
\hline Left Rear Temperature & ${ }^{\circ} \mathrm{F}$ \\
\hline Right Rear Temperature & ${ }^{\circ} \mathrm{F}$ \\
\hline Left Forward Trailer Axle Temperature & ${ }^{\circ} \mathrm{F}$ \\
\hline Right Forward Trailer Axle Temperature & ${ }^{\circ} \mathrm{F}$ \\
\hline Left Rear Trailer Axle Temperature & \\
\hline Right Rear Trailer Axle Temperature & \\
\hline
\end{tabular}


A sample plot of speed and braking data are shown in Figure 2. This plot shows speed, deceleration, and brake application pressure for one of the constant-pressure stops performed at the 60,000-lb GVW loading condition with the rear trailer brakes disabled. For this stop, the original speed was approximately $20 \mathrm{mph}$ before the brakes were applied at $15 \mathrm{psi}$.

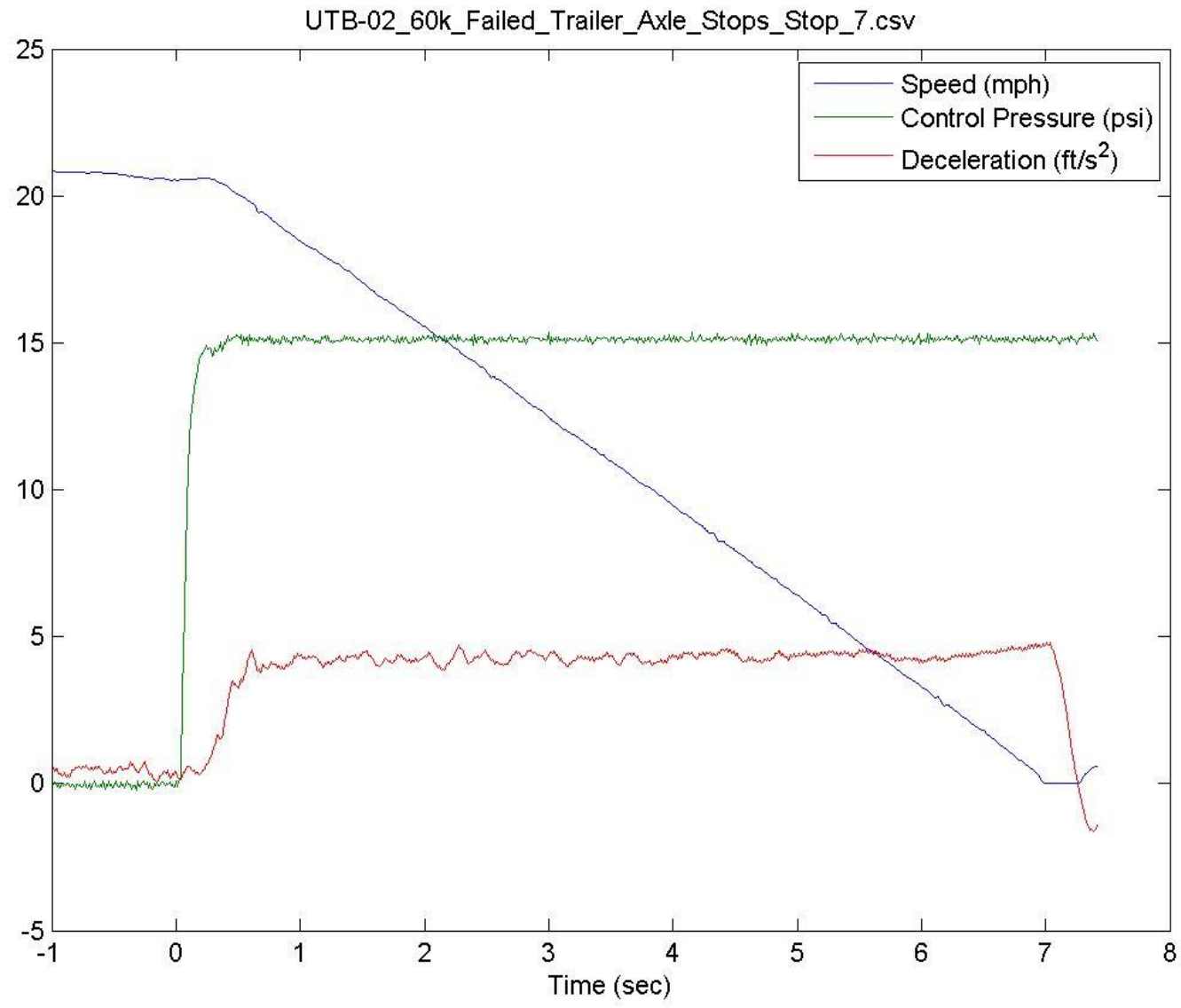

Figure 2. Time history plot of data from a constant-pressure stop.

Weigh tickets were obtained for each loading condition to determine the distribution of the load across the vehicle by axle group. A complete list of all test weights along with the nominal weight values used throughout this report is shown in Table 4. 
Table 4. Test Weights (lb)

\begin{tabular}{llcccc}
\hline \multicolumn{1}{c}{ Nominal } & Abbreviation & Steer & Drives & Trailer & GVW \\
\hline 60,000 & 60k & 12,630 & 24,490 & 22,920 & 60,040 \\
80,000 Balanced & 80k Bal & 12,810 & 32,640 & 34,590 & 80,040 \\
80,000 Unbalanced & 80k Unbal & 13,200 & 38,710 & 28,100 & 80,010 \\
91,000 & $91 \mathrm{k}$ & 13,140 & 38,240 & 40,060 & 91,440 \\
97,000 & $97 \mathrm{k}$ & 12,660 & 33,390 & 51,070 & 97,120 \\
106,000 & $106 \mathrm{k}$ & 13,710 & 45,080 & 47,550 & 106,340 \\
116,000 & $116 \mathrm{k}$ & 13,780 & 48,770 & 53,550 & 116,100 \\
\hline
\end{tabular}

A number of signals were collected during the PBBT tests as well. The information listed in Table 5 was collected at $10 \mathrm{~Hz}$ for each axle during testing of the service brakes.

Table 5. PBBT Service Brake Streaming Data

\begin{tabular}{lc}
\hline Parameter & Units \\
\hline Time & $\mathrm{sec}$ \\
Brake Force Left & $\mathrm{lb}$ \\
Lock-up Left & $\mathrm{lb}$ \\
Brake Force Right & $\mathrm{lb}$ \\
Lock-up Right & $\mathrm{lb}$ \\
Weight Left & $\mathrm{lb}$ \\
Weight Right & $\mathrm{lb}$ \\
Control Pressure & $\mathrm{psi}$ \\
Chamber Pressure & $\mathrm{psi}$ \\
\hline
\end{tabular}

\subsection{CALCULATION OF KEY PARAMETERS FOR EACH STOP}

Link Engineering, the company which performed the tests and collected the data referenced in Section 3.1, provided several key parameters for each stopping test. These parameters are listed below in Table 6. The values for each of these parameters for every stopping test performed appear in Appendix A. 
Table 6. Parameters Calculated for Each Stopping Test

\begin{tabular}{lc}
\hline \multicolumn{1}{c}{ Measure } & Units \\
\hline Stop \# & -- \\
Target Speed & $\mathrm{mph}$ \\
Actual Speed & $\mathrm{mph}$ \\
Actual Stop Distance & $\mathrm{ft}$ \\
Corrected Stop Distance & $\mathrm{ft}$ \\
Average Primary Control Pressure & $\mathrm{psi}$ \\
Average Secondary Control Pressure & $\mathrm{psi}$ \\
Average Deceleration & $\mathrm{ft} / \mathrm{s}^{2}$ \\
Stop Time (sec) & $\mathrm{sec}$ \\
\hline
\end{tabular}

Stopping distance was determined from a GPS with an internal accelerometer that is used to correct the data points between actual measurements from GPS position. The output from this accelerometer was used by the data-acquisition system to record the actual distance from the beginning of the braking event (triggered by using a pedal switch on the brake pedal) and the end of the braking event (triggered when the vehicle speed decreased to $0.4 \mathrm{mph}$ ). The stop time was determined by the time between these two triggers. Like the stopping-distance measurement, the deceleration was also measured with an accelerometer with the data being filtered to reduce the noise. Average pressures and decelerations were calculated from the data beginning $1.0 \mathrm{sec}$ after the braking event is initiated until the end of the stop.

\subsection{ADDITIONAL DATA COMMENTS}

As indicated in Section 2.3.4, the brake stroke length was also monitored throughout the testing to ensure the automatic slack adjusters were functioning properly. While this data was not used in the analysis presented in this report, it is included in Appendix B for reference.

During the course of testing with the $97,000-1 b$ GVW load, a brake component failed. Following repair, tests resumed with the next loading condition in the test sequence, 106,000-lb GVW. Consequently, data for the final brake condition — disabled pair of trailer brakes — was not collected for the 97,000-lb load. 


\section{ANALYSIS OF PANIC STOP DATA}

Panic stops provide insight into the maximum brake force that can be developed, typical of an emergency situation where a driver would need to slam on the brakes without regard to smooth deceleration. Decelerations determined from this test data represents the maximum possible under the tested scenario (brake condition, initial speed, and road condition), and the stopping distances similarly represent the shortest distances possible. Note that driver response time is not a factor in these tests; the tests represent a driver response time of zero seconds.

\subsection{TRACTOR TESTING WITH A CONTROL TRAILER}

The first set of stopping tests conducted were FMVSS-121-style panic stops from 20 and $60 \mathrm{mph}$ with an unbraked control trailer attached to the tractor with a GVW of approximately 56,000 lb. While these tests did not represent typical in-service loading events, they provided confirmation that the tractor still meets the brake performance standard for new equipment. FMVSS-121 specifies that for "loaded tractors with three axles and a GVWR of 70,000 lb or less...tested with an unbraked control trailer," the 20-mph stopping distance must be no more than $30 \mathrm{ft}$ and the 60-mph stopping distance must be no more than 250 $\mathrm{ft}^{1}{ }^{1}$ FMVSS-121-style stopping tests were performed at both 20 and $60 \mathrm{mph}$ and were repeated for disabled brakes on a drive axle as well. The actual FMVSS-121 stopping distance (tested at $60 \mathrm{mph}$ with fully-functioning tractor brakes) was $225 \mathrm{ft}$, below the maximum of $250 \mathrm{ft}$ specified by FMVSS-121 (RSD requirement). The 20-mph stopping distance was $27.7 \mathrm{ft}$, also meeting the FMVSS-121 requirement (30 ft maximum).

\subsection{OVERVIEW OF RESULTS FOR 20-MPH PANIC STOPS}

The average stopping distances for the 20-mph panic stops are shown in Figure 3. Table 7 presents this same information in tabular form. For all of these tests, low variability was observed within the three repetitions of each brake/loading condition; thus, a single average value is sufficient to observe general trends in the data. The distances for all the regular panic stops for all loads and brake conditions tested were under the 40-ft limit specified in FMCSR 393.52(3).

1 http://www.nhtsa.gov/DOT/NHTSA/Rulemaking/Rules/Associated\%20Files/121_Stopping_Distance_FR.pdf (Table II p. 143) 


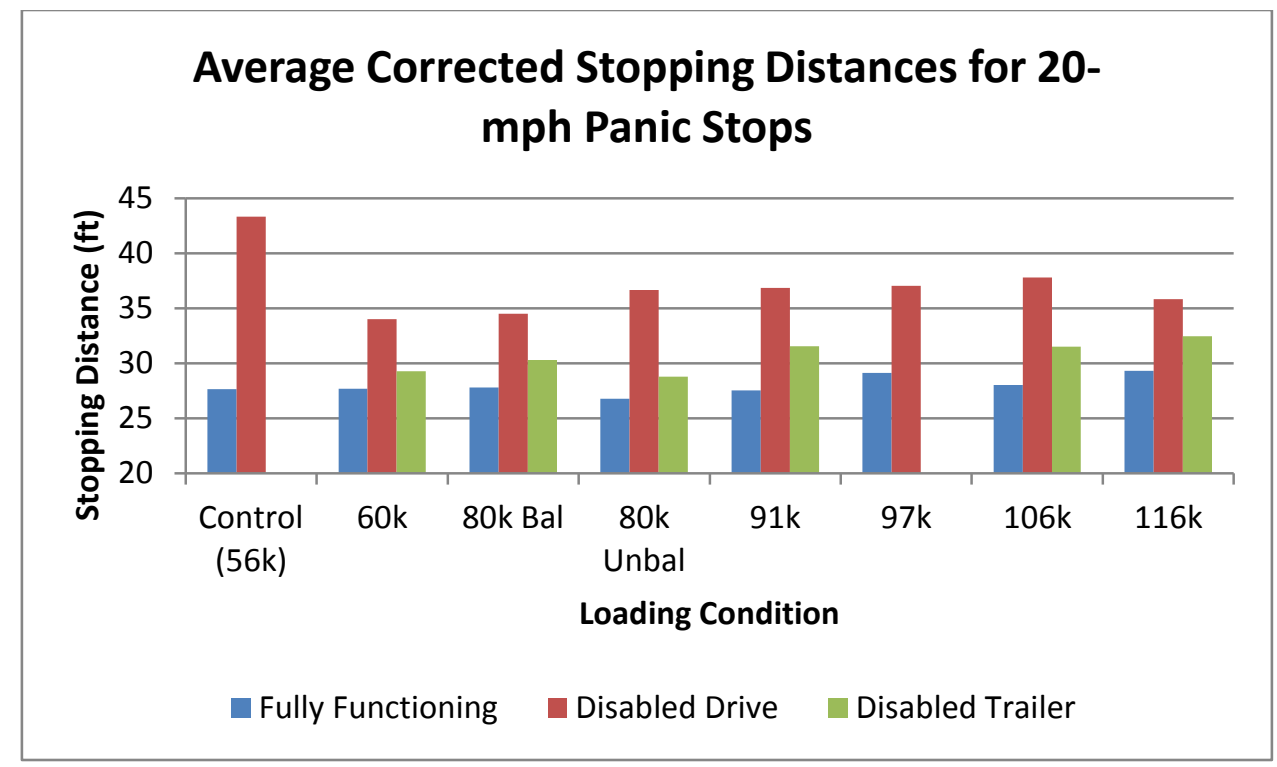

Figure 3. Comparison of stopping distances for 20-mph panic stops.

Table 7. Average Corrected Stopping Distance for 20-mph Panic Stops

\begin{tabular}{lccc}
\hline \multirow{2}{*}{ Loading Condition (lb) } & \multicolumn{3}{c}{ Stopping Distance (ft) } \\
\cline { 2 - 4 } & $\begin{array}{c}\text { Fully } \\
\text { Functioning }\end{array}$ & $\begin{array}{c}\text { Disabled } \\
\text { Drive }\end{array}$ & $\begin{array}{c}\text { Disabled } \\
\text { Trailer }\end{array}$ \\
\hline Control Trailer (56,000) & 27.7 & 43.3 & -- \\
60,000 Load & 27.7 & 34.0 & 29.3 \\
80,000 Balanced Load & 27.8 & 34.5 & 30.3 \\
80,000 Unbalanced Load & 26.8 & 36.7 & 28.8 \\
91,000 Load & 27.6 & 36.9 & 31.6 \\
97,000 Load & 29.1 & 37.1 & -- \\
106,000 Load & 28.0 & 37.8 & 31.5 \\
116,000 Load & 29.3 & 35.9 & 32.5 \\
\hline
\end{tabular}

\subsection{OVERVIEW OF RESULTS FOR 60-MPH PANIC STOPS}

The average stopping distances for the 60-mph panic stops are shown Figure 4 (actual values in Table 8). For these tests as well, the variability within the three repetitions of each brake/loading condition was low. 


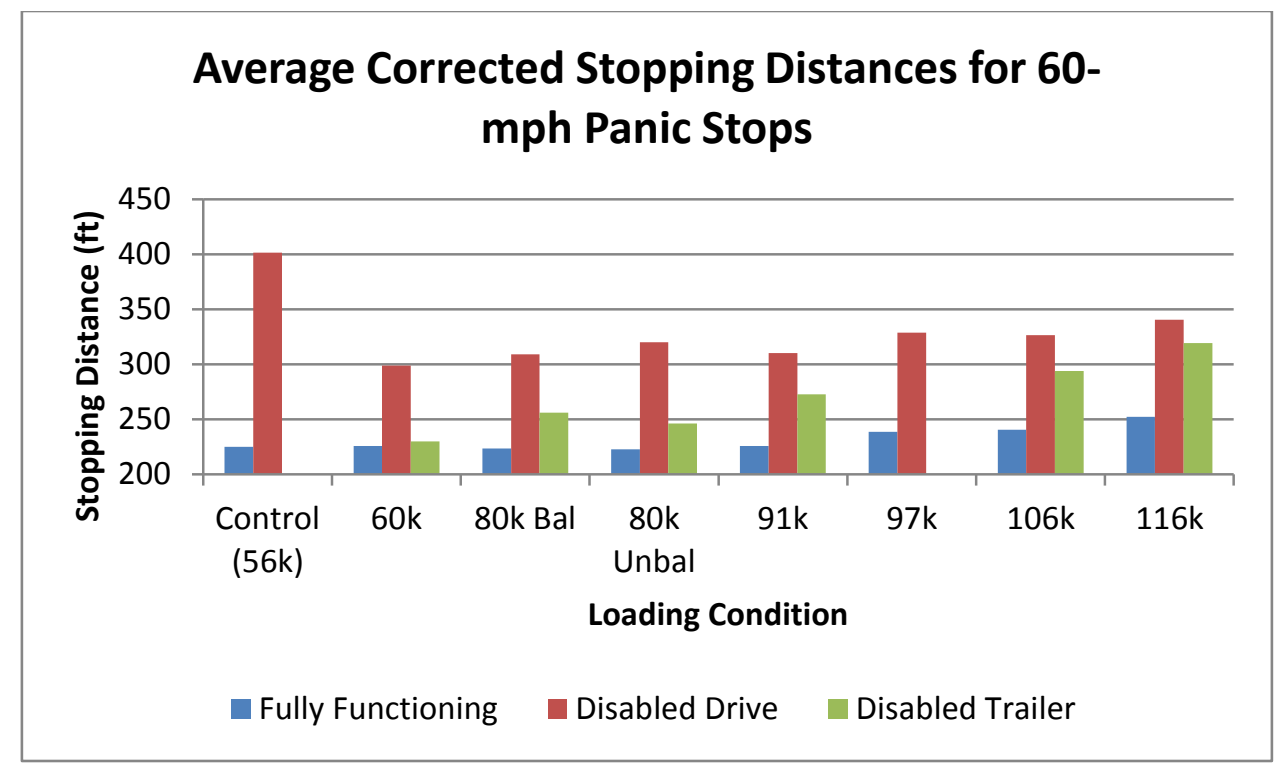

Figure 4. Comparison of stopping distances for 60-mph panic stops

Table 8. Average Corrected Stopping Distances for 60-mph Panic Stops

\begin{tabular}{lccc}
\hline \multirow{2}{*}{ Loading Condition (lb) } & \multicolumn{3}{c}{ Stopping Distance (ft) } \\
\cline { 2 - 4 } & $\begin{array}{c}\text { Fully } \\
\text { Functioning }\end{array}$ & $\begin{array}{c}\text { Disabled } \\
\text { Drive }\end{array}$ & $\begin{array}{c}\text { Disabled } \\
\text { Trailer }\end{array}$ \\
\hline Control Trailer (56,000) & 225.0 & 401.7 & -- \\
60,000 Load & 228.9 & 299.1 & 229.8 \\
80,000 Balanced Load & 223.6 & 309.3 & 256.1 \\
80,000 Unbalanced Load & 222.9 & 320.3 & 246.4 \\
91,000 Load & 225.8 & 310.3 & 272.7 \\
97,000 Load & 238.8 & 329.0 & -- \\
106,000 Load & 240.5 & 326.6 & 294.2 \\
116,000 Load & 252.4 & 340.7 & 319.5 \\
\hline
\end{tabular}

As described previously, the control trailer testing was performed with an unbraked control trailer; thus, the panic stops performed with the control trailer with disabled drive brakes represent a stop in which the total braking force was provided by the steer axle and one drive axle only.

\subsection{OBSERVED TRENDS IN PANIC STOP DATA}

The test data for both 20- and 60-mph stopping tests revealed a difference in brake force supplied depending on which brakes were disabled. For the test scenarios where one set of brakes was disabled, disabling a pair of drive axle brakes resulted in a greater stopping distance (decreased braking force) than disabling a pair of trailer brakes. The relationship held true for both initial speeds and all loading conditions. Thus, for the vehicle tested, more brake force was generated by the drive axle brakes than the trailer axle brakes. 
As expected, increases in load resulted in corresponding increase in stopping distance, with a few minor exceptions for unknown reasons in the 20-mph stopping data.

\subsection{ANALYSIS OF TIRE LOAD CAPACITY}

Another area of concern to policy-makers considering loading regulations includes tire capacity. For the purposes of this testing, all tire pressures were set at the manufacturer-specified capacity to accommodate the maximum load (details in Table 1 and Table 2). Tire capacities for each axle group are summarized and compared to the test loads in Table 9.

Table 9. Tire Load Capacity for Loading Conditions

\begin{tabular}{|c|c|c|c|c|}
\hline Load Condition (lb) & $\begin{array}{c}\text { GVW } \\
\text { (lb) }\end{array}$ & $\begin{array}{c}\text { Steer } \\
\text { Axle } \\
\text { (lb), } \\
\text { Capacity }\end{array}$ & $\begin{array}{l}\text { Drive Axle } \\
\text { Group } \\
\text { (lb), } \\
\text { Capacity } \\
\end{array}$ & $\begin{array}{c}\text { Trailer Axle } \\
\text { Group } \\
\text { (lb), } \\
\text { Capacity }\end{array}$ \\
\hline Tire Capacity & - & 14,320 & 45,400 & 52,880 \\
\hline Control Trailer & 55,860 & $\begin{array}{l}13,340 \\
93.2 \%\end{array}$ & $\begin{array}{l}38,020 \\
83.7 \% \\
\end{array}$ & \\
\hline 60,000 Load & 60,040 & $\begin{array}{l}12,630 \\
88.2 \% \\
\end{array}$ & $\begin{array}{l}24,490 \\
53.9 \% \\
\end{array}$ & $\begin{array}{l}22,920 \\
43.3 \% \\
\end{array}$ \\
\hline 80,000 Balanced Load & 80,040 & $\begin{array}{l}12,810 \\
89.5 \% \\
\end{array}$ & $\begin{array}{l}32,640 \\
71.9 \% \\
\end{array}$ & $\begin{array}{l}34,590 \\
65.4 \% \\
\end{array}$ \\
\hline 80,000 Unbalanced Load & 80,010 & $\begin{array}{l}13,200 \\
92.2 \% \\
\end{array}$ & $\begin{array}{l}38,710 \\
85.3 \% \\
\end{array}$ & $\begin{array}{l}28,100 \\
53.1 \% \\
\end{array}$ \\
\hline 91,000 Load & 91,440 & $\begin{array}{l}13,140 \\
91.8 \% \\
\end{array}$ & $\begin{array}{l}38,240 \\
84.2 \% \\
\end{array}$ & $\begin{array}{l}40,060 \\
75.8 \% \\
\end{array}$ \\
\hline 97,000 Load & 97,120 & $\begin{array}{l}12,660 \\
88.4 \% \\
\end{array}$ & $\begin{array}{l}33,390 \\
73.5 \% \\
\end{array}$ & $\begin{array}{l}51,070 \\
96.6 \% \\
\end{array}$ \\
\hline 106,000 Load & 106,340 & $\begin{array}{l}13,710 \\
95.7 \% \\
\end{array}$ & $\begin{array}{l}45,080 \\
99.3 \% \\
\end{array}$ & $\begin{array}{l}47,550 \\
89.9 \% \\
\end{array}$ \\
\hline 116,000 Load & 116,100 & $\begin{array}{l}13,780 \\
96.2 \%\end{array}$ & $\begin{array}{c}48,770 \\
107.4 \% *\end{array}$ & $\begin{array}{c}53,550 \\
101.3 \% *\end{array}$ \\
\hline
\end{tabular}

*Due to load positioning in these configurations, an overload condition was created for the rating of the tires available for testing. This was noted and will be addressed in future testing. 


\section{ANALYSIS OF PBBT DATA}

\subsection{OVERVIEW OF RESULTS}

The PBBT tests were performed before and after stopping tests for each loading and brake condition. Unless otherwise specified, the numbers presented are averages of the two tests performed. Results of each individual PBBT test (including wheel-end-specific values) are included in Appendix C. The PBBT overall vehicle scores are summarized in Table 10.

Table 10. PBBT Scores (Average)

\begin{tabular}{lccc}
\hline Load Condition (lb) & $\begin{array}{c}\text { Fully } \\
\text { Functioning }\end{array}$ & $\begin{array}{c}\text { Disabled } \\
\text { Drive }\end{array}$ & $\begin{array}{c}\text { Disabled } \\
\text { Trailer }\end{array}$ \\
\hline Control (Tractor Only) & $54.6 \%$ & & \\
60,000 Load & $69.7 \%$ & $56.5 \%$ & $52.2 \%$ \\
80,000 Balanced Load & $67.4 \%$ & $55.8 \%$ & $49.0 \%$ \\
80,000 Unbalanced Load & $65.9 \%$ & $53.6 \%$ & $52.1 \%$ \\
91,000 Load & $65.8 \%$ & $55.4 \%$ & $48.4 \%$ \\
97,000 Load & $62.2 \%$ & $51.2 \%$ & \\
106,000 Load & $61.9 \%$ & $50.0 \%$ & $45.3 \%$ \\
116,000 Load & $58.1 \%$ & $47.3 \%$ & $45.0 \%$ \\
\hline
\end{tabular}

\subsection{ESTIMATES OF DISABLED-BRAKE RESULTS}

The results of the PBBT tests performed when all brakes were fully functioning were used to estimate the PBBT scores for the situations where the brakes on a particular actual were disabled. This brake efficiency estimation was determined from the total braking forces of the remaining axles divided by the PBBT-reported weights for all axles. These estimated results are compared to the actual values in Table 11 below and graphed in Figure 5.

Table 11. Comparison of Actual and Estimated PBBT Scores

\begin{tabular}{lc||cc||cc}
\hline \multirow{2}{*}{ Load Condition (lb) } & \multirow{2}{*}{$\begin{array}{c}\text { Fully } \\
\text { Functioning }\end{array}$} & \multicolumn{2}{c||}{ Disabled Drive } & \multicolumn{2}{c}{ Disabled Trailer } \\
\cline { 2 - 5 } & Actual & Expected & Actual & Expected \\
\hline Control (Tractor Only) & $54.6 \%$ & & & & \\
60,000 Load & $69.7 \%$ & $56.5 \%$ & $57.0 \%$ & $52.2 \%$ & $54.4 \%$ \\
80,000 Balanced Load & $67.4 \%$ & $55.8 \%$ & $55.1 \%$ & $49.0 \%$ & $50.7 \%$ \\
80,000 Unbalanced Load & $65.9 \%$ & $53.6 \%$ & $51.7 \%$ & $52.1 \%$ & $52.0 \%$ \\
91,000 Load & $65.8 \%$ & $55.4 \%$ & $53.8 \%$ & $48.4 \%$ & $49.0 \%$ \\
97,000 Load & $62.2 \%$ & $51.2 \%$ & $53.0 \%$ & & \\
106,000 Load & $61.9 \%$ & $50.0 \%$ & $50.9 \%$ & $45.3 \%$ & $47.7 \%$ \\
116,000 Load & $58.1 \%$ & $47.3 \%$ & $46.6 \%$ & $45.0 \%$ & $45.5 \%$ \\
\hline
\end{tabular}




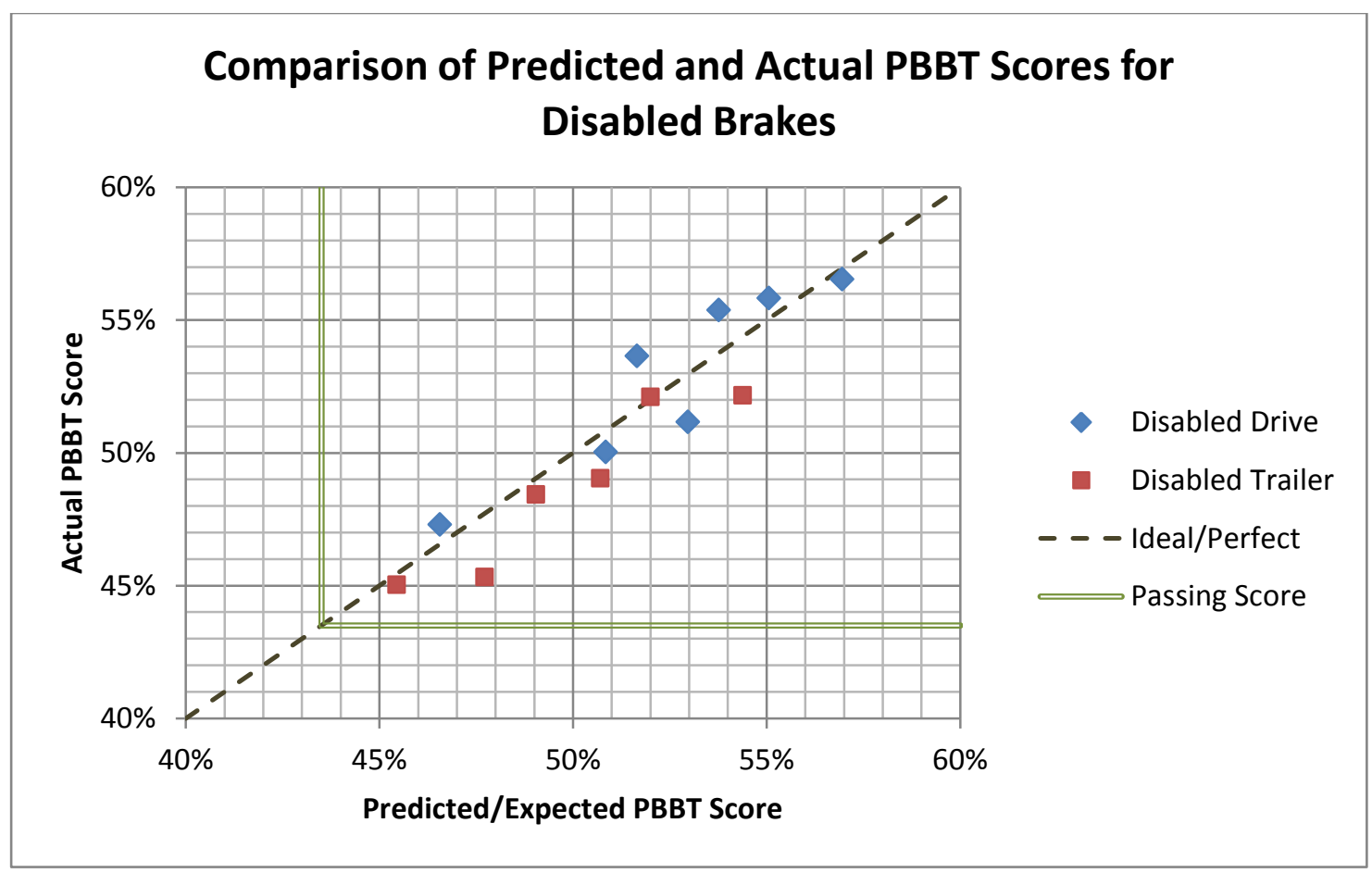

Figure 5. Comparison of predicted and actual PBBT scores for disabled brake scenarios.

As shown in Figure 5, these estimates were a fairly accurate predictor of the actual PBBT scores for these conditions, generally within $1-2 \%$. The predictions for the disabled trailer brake scenario tended to be generally lower than the actual values, whereas the predictions for the disabled drive brake scenario were more evenly balanced with over- and under-estimates.

\subsection{EFFECT OF LOAD AND DEFECT POSITION ON BRAKE EFFICIENCY}

The average PBBT scores for each weight and loading condition are shown in Figure 6. As expected, the PBBT score decreases with increasing weight. However, unlike the stopping distance tests, the performance was better when a set of drive axle brakes was disabled rather that a set of trailer axle brakes. 


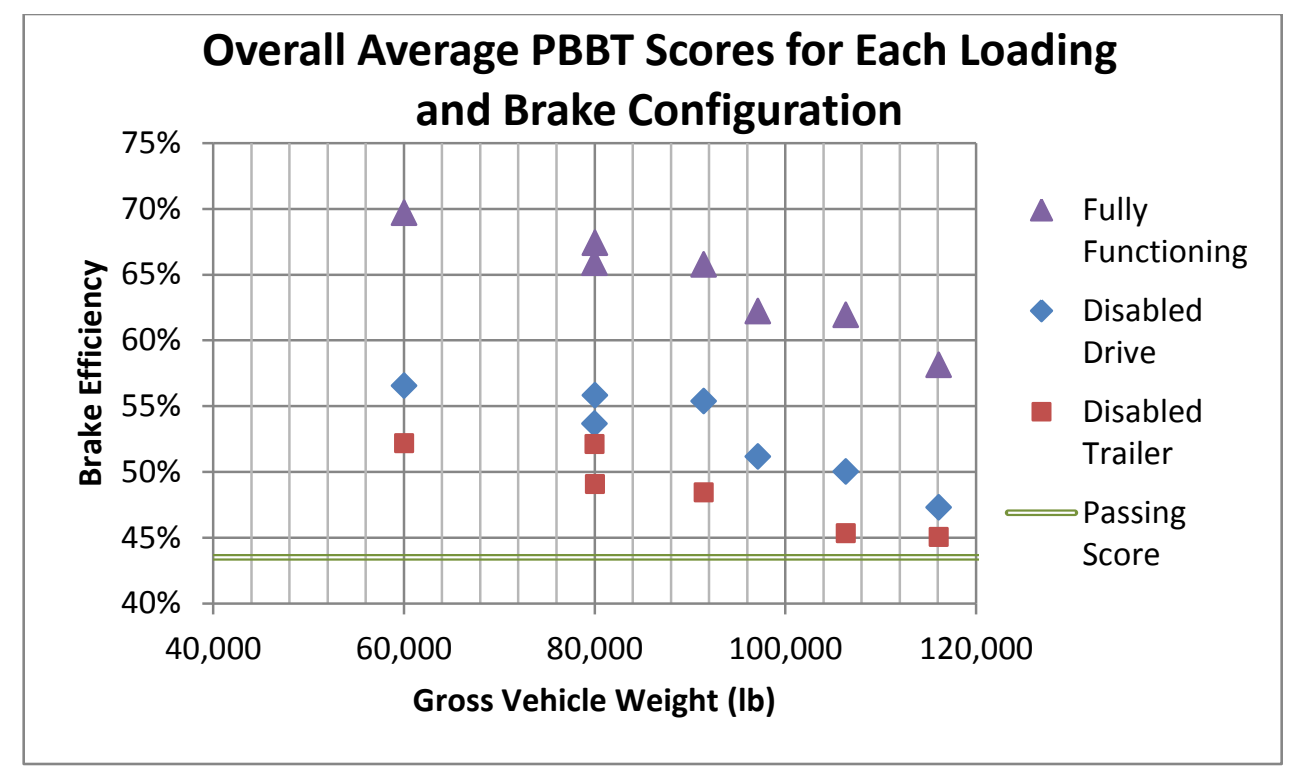

Figure 6. PBBT scores by brake condition and loading.

Actual test weights, including weight distribution by axle group, appear in Table 4.

\subsection{COMPARISON OF SCALE-AND PBBT-REPORTED WEIGHTS}

Brake efficiency is calculated by dividing the sum of the wheel-end brake forces by the sum of the wheelend weights. The GVW measured and used by the PBBT machine is compared to the GVW reported in the weight ticked from the scale in Figure 7. As shown in this figure, the PBBT consistently measures a total weight value approximately 5,000 lb lower than the GVW measured on the scale. This is likely because unlike the pit scale, the axles are weighed individually and the weighing surface is not level with respect to the length of the vehicle. 


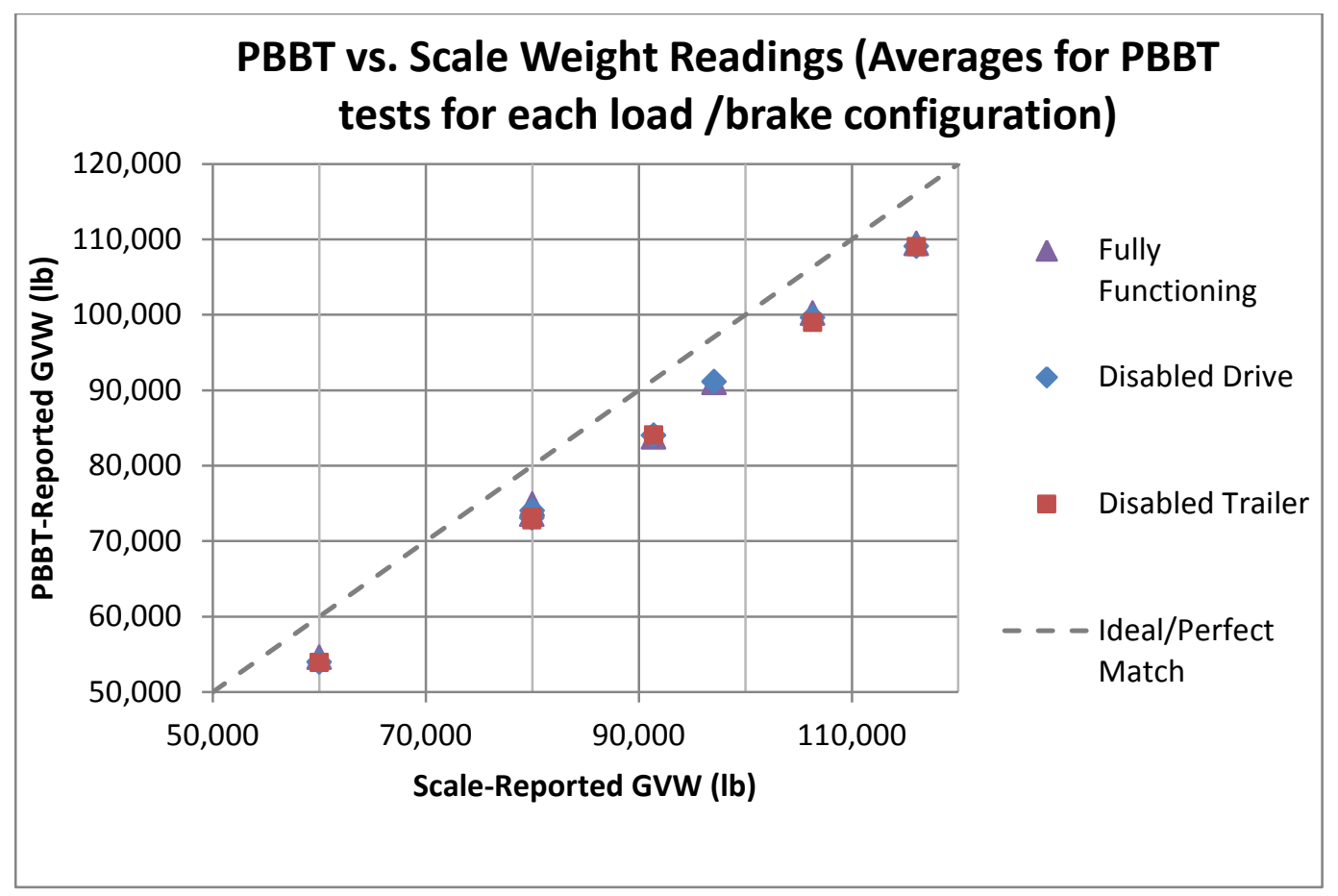

Figure 7. Comparison of PBBT and scale-reported GVW 


\section{ANALYSIS OF CONSTANT-PRESSURE STOP DATA}

\subsection{BACKGROUND}

Both North American Standard Level-1 inspections and drivers' pre-trip inspections include a component to visually inspect the vehicle's braking system. Because they are visual methods, they have limited ability to determine brake performance. Although the PBBT provides a quantitative indicator of vehicle braking ability, it requires access to specialized equipment. This section describes an on-board system which will provide a real-time brake indicator based on dynamic braking data collected on board the vehicle. Such a system could be used by drivers and maintenance personnel to monitor their vehicles' braking systems, supporting preventative maintenance and providing notification of equipment problems. The system could also provide input to a number of other systems such as the Wireless Roadside Inspection system, providing advisory data to enforcement and fleet personnel regarding a commercial motor vehicle's (CMV's) brake system.

A cursory analysis of stopping test data for over-the-road CMVs collected $2008-2009^{2}$ has indicated that the actual pressure-deceleration relationship is linear from the crack pressure (typically around $10 \mathrm{psi}$ ) up until about 60 psi. The higher-pressure region (about 60 psi up to the maximum, about 100-110 psi), is highly nonlinear. Stopping tests such as those in accordance with the FMVSS-121 guidelines or FMCSR 393.5(a)(3) provide stopping distance (typically expressed in feet, and the typical performance-based brake test provides brake efficiency (ratio of total braking force to GVW, equivalent to deceleration in g's). However, both of these metrics are based on tests conducted in the higher, nonlinear pressure region, and are thus not well correlated to typical day-to-day braking events performed at lower brake application pressures (shown in the Medium Truck Duty Cycle research ${ }^{3}$ to generally be below $30 \mathrm{psi}$ ).

ORNL is seeking to develop a system which will determine, on a real-time basis from in-service activity, the condition of a CMV's braking system by monitoring deceleration as a function of brake application pressure. The algorithm will ultimately make use of pressure data from a brake application pressure sensor located at the treadle valve, speed data from either the data bus native to the vehicle (J1939 or J1708/J1587) or an installed GPS (may be present as part of a telematics device), weight data from an onboard self-weighing system (in this particular research substituted with weigh ticket data), and a telematics device where processing/analysis functions will reside. The system will use currentlyavailable, commercial, off-the-shelf technology, and the algorithm will make use of trends in the CMVs pressure-deceleration curves to identify degradations in brake performance.

\subsection{GENERAL OBSERVATIONS FROM TEST DATA}

Constant-pressure stopping tests were performed by bringing the test vehicle up to a certain speed and applying a constant primary control pressure (using a pressure regulator) until the vehicle came to a complete stop. Speed and brake application pressure data were collected and used to determine average deceleration, normalized stopping distance, elapsed time, and other summary information for each test run. Constant-pressure stops were performed with 60,000-lb and 80,000-lb loads; at 15-psi, 25-psi, 35psi, 45-psi, and 55-psi brake application pressures; and from 20-mph and 60-mph starting speeds. Two runs were performed for each test configuration.

\footnotetext{
2 Steven J. Shaffer, Amy M. Long, U14: Field Testing and Analysis of Braking Performance of In-Service Trucks, National Transportation Research Center, Inc., 2009.

3 Oscar Franzese, Mary Beth Lascurain, Gary Capps, Medium Truck Duty Cycle Data from Real-World Driving Environments: Project Interim Report, Oak Ridge National Laboratory, 2010.
} 
Deceleration data for each constant-pressure test is shown as a function of primary brake control pressure in Figure 8 (60,000-lb load) and Figure 9 (80,000-lb load).

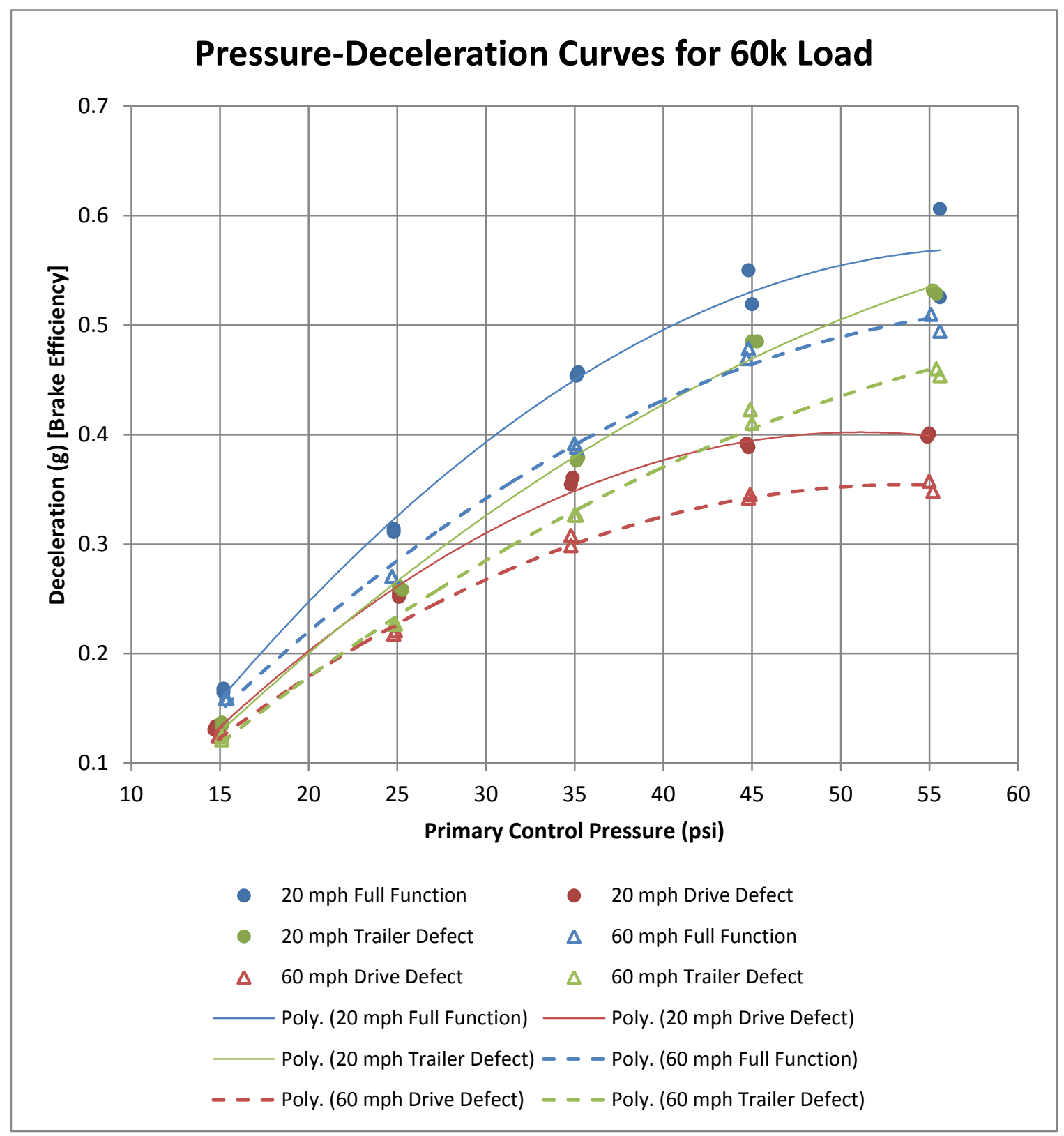

Figure 8. Pressure-deceleration curves for $60,000 \mathrm{lb}$ GVW load. 


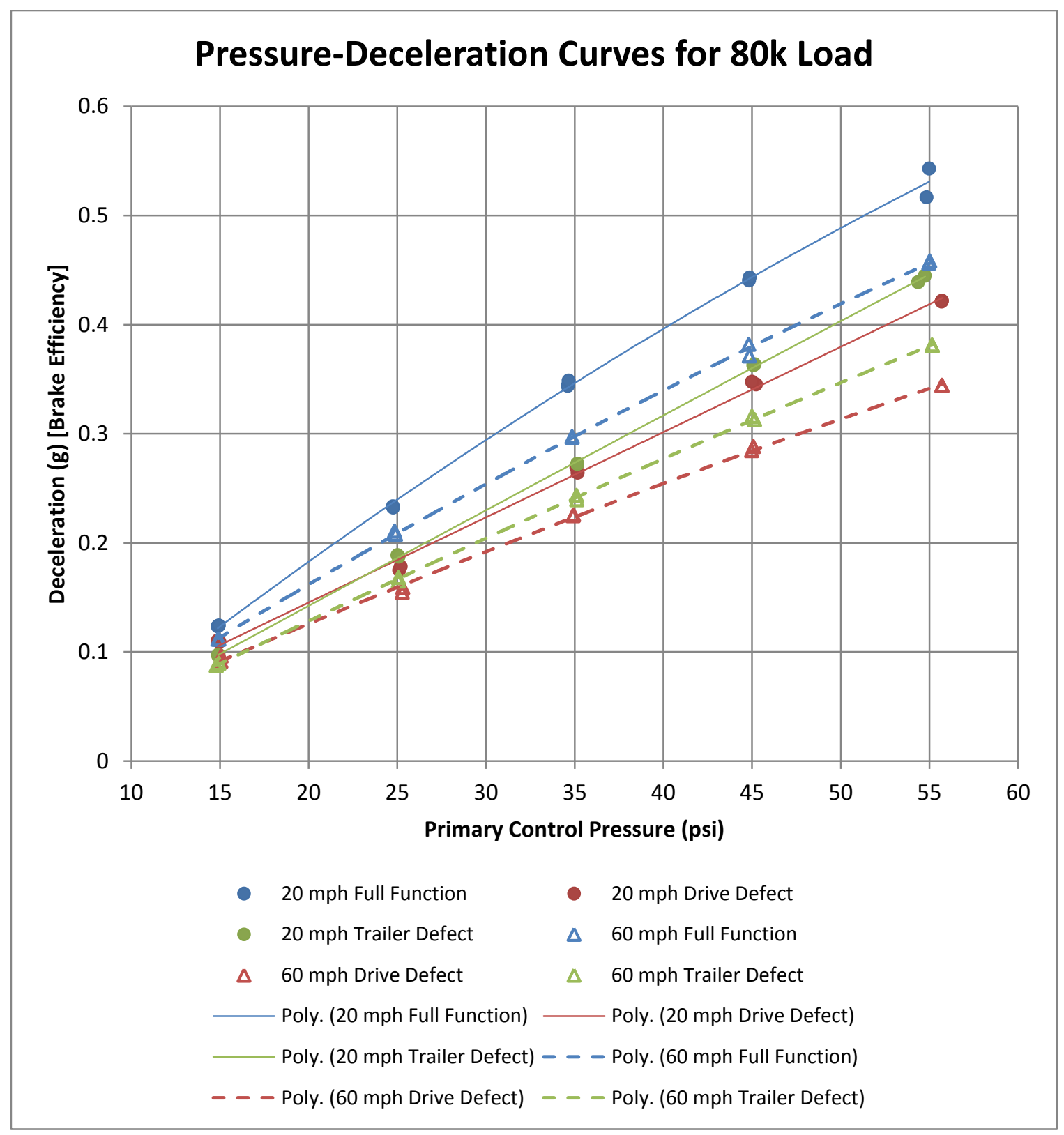

Figure 9. Pressure-deceleration curves for 80,000-lb GVW load.

\subsubsection{Linearity}

Previous constant pressure stopping tests only went up to about $30 \mathrm{mph}$, and data appeared very linear (first-order polynomial). However, with the addition of the higher pressures in this test (up to 55 psi), the fit is better approximated by a second-order polynomial, indicating that the linear pressure region terminates around $50 \mathrm{psi}$ (for the test vehicle). With the omission of the highest test pressure (55 psi), however, the remaining data $(15,25,35$, and 45 psi) is well represented (correlation of more than 95\%) by a linear fit for each of the twelve speed/load/brake configurations as shown in Figure 10 and Figure 11. 


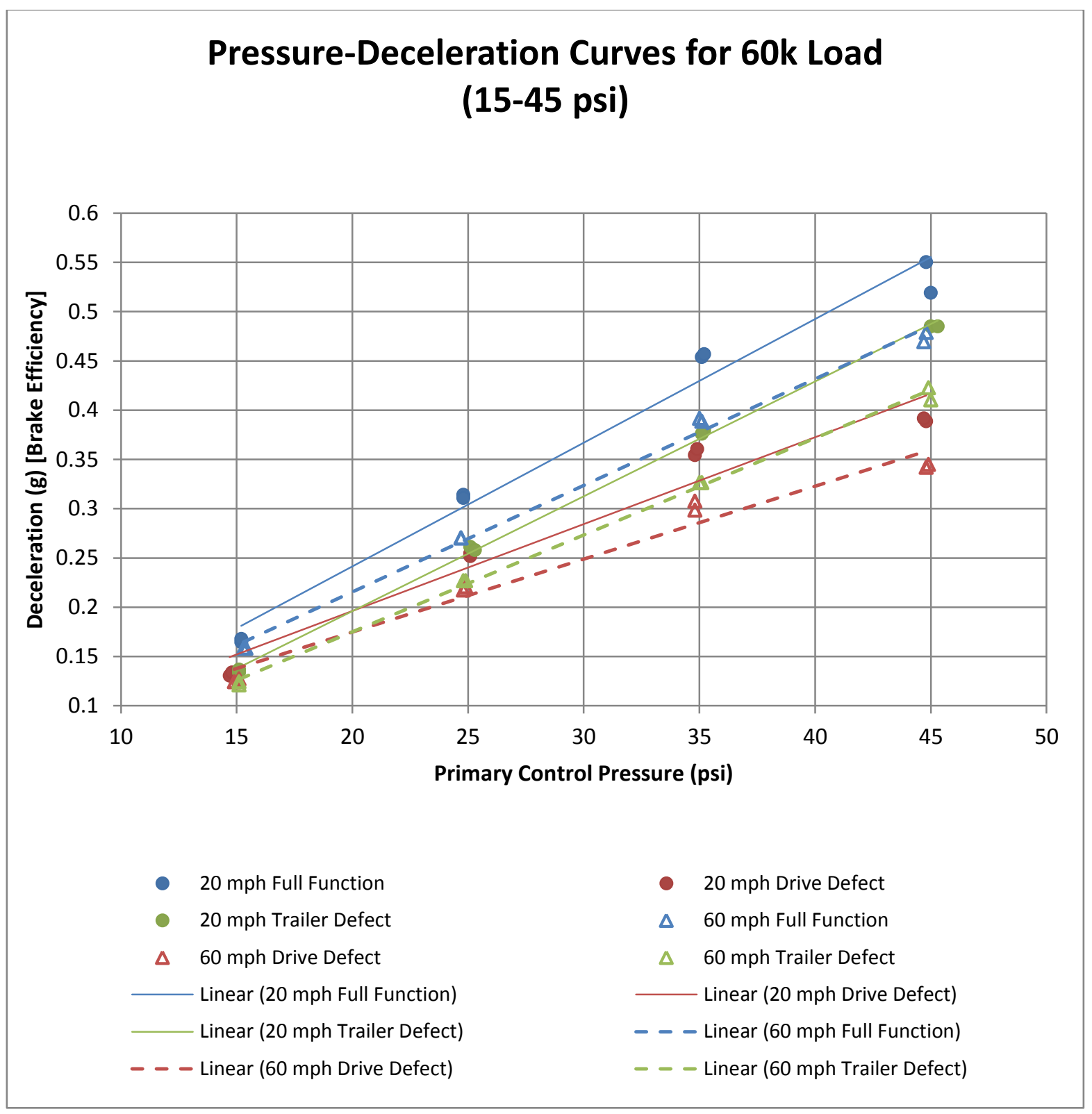

Figure 10. Pressure-decelaration curves for 60,000-lb GVW loading condition (15-45 psi). 


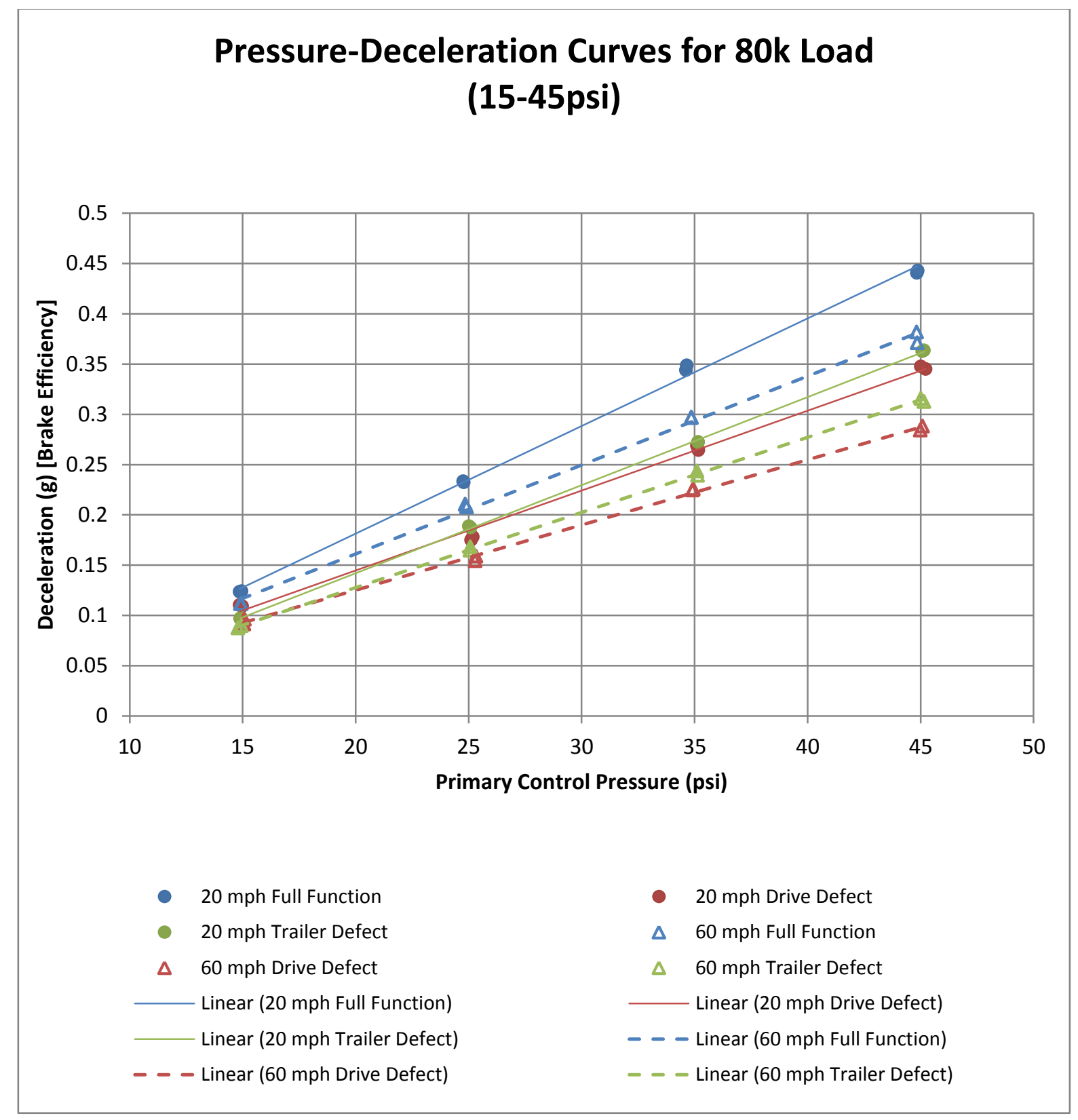

Figure 11. Pressure-deceleration curves for 80,000-lb GVW loading condition (15-45 psi).

An implication for future testing is that the linear model for the pressure-deceleration relationship should only be based on and used for brake application pressures below approximately 50 psi.

\subsubsection{Effect of Speed}

One item of interest from the initial exploratory analysis was the effect of initial speed (20 vs. $60 \mathrm{mph}$ ) on deceleration. This was not seen in previous research ${ }^{4}$, where only 20- and 30-mph tests were conducted. For equivalent loading, braking condition, and brake application pressure, the tests conducted from higher

4 Mary Beth Lascurain, Oscar Franzese, Gary Capps, Real-Time Dynamic Brake Assessment Proof of Concept Final Report, Oak Ridge National Laboratory, 2011. 
speeds had lower average deceleration. For the most recent analysis, speed and deceleration plots (Figure 12 and Figure 13 respectively) were generated to compare the stopping data for both starting speeds in the below-20-mph region. (Here, the data is aligned at the 19-mph point with braking events marked with $x$ 's. These graphs reveal that the difference in deceleration is also present in the lower-speed region of the data, not simply a result of unexpectedly low deceleration in the 20-to-60-mph region.

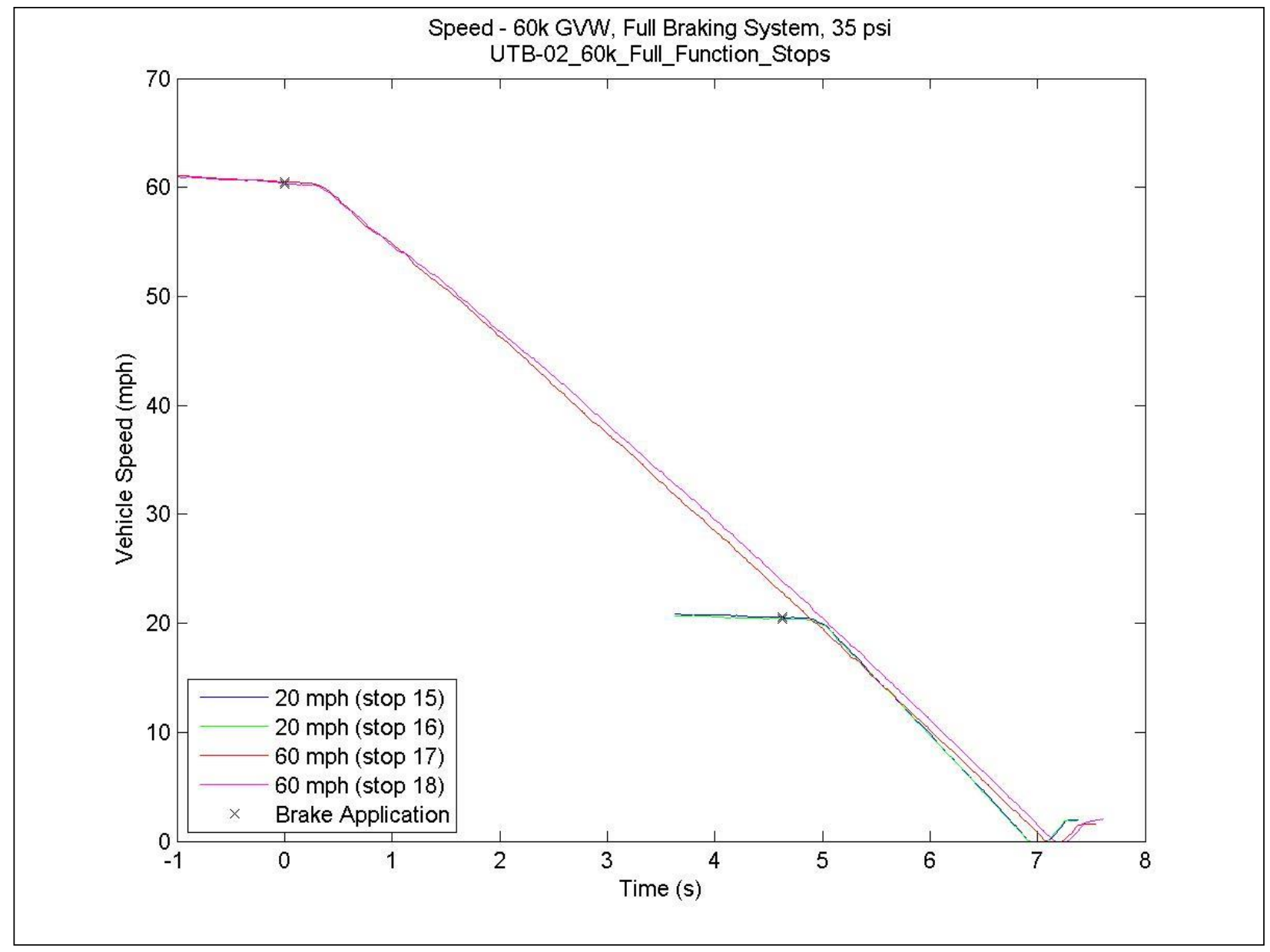

Figure 12. Comparison of sample speed profiles for 20- and 60-mph constant-pressure stops. 


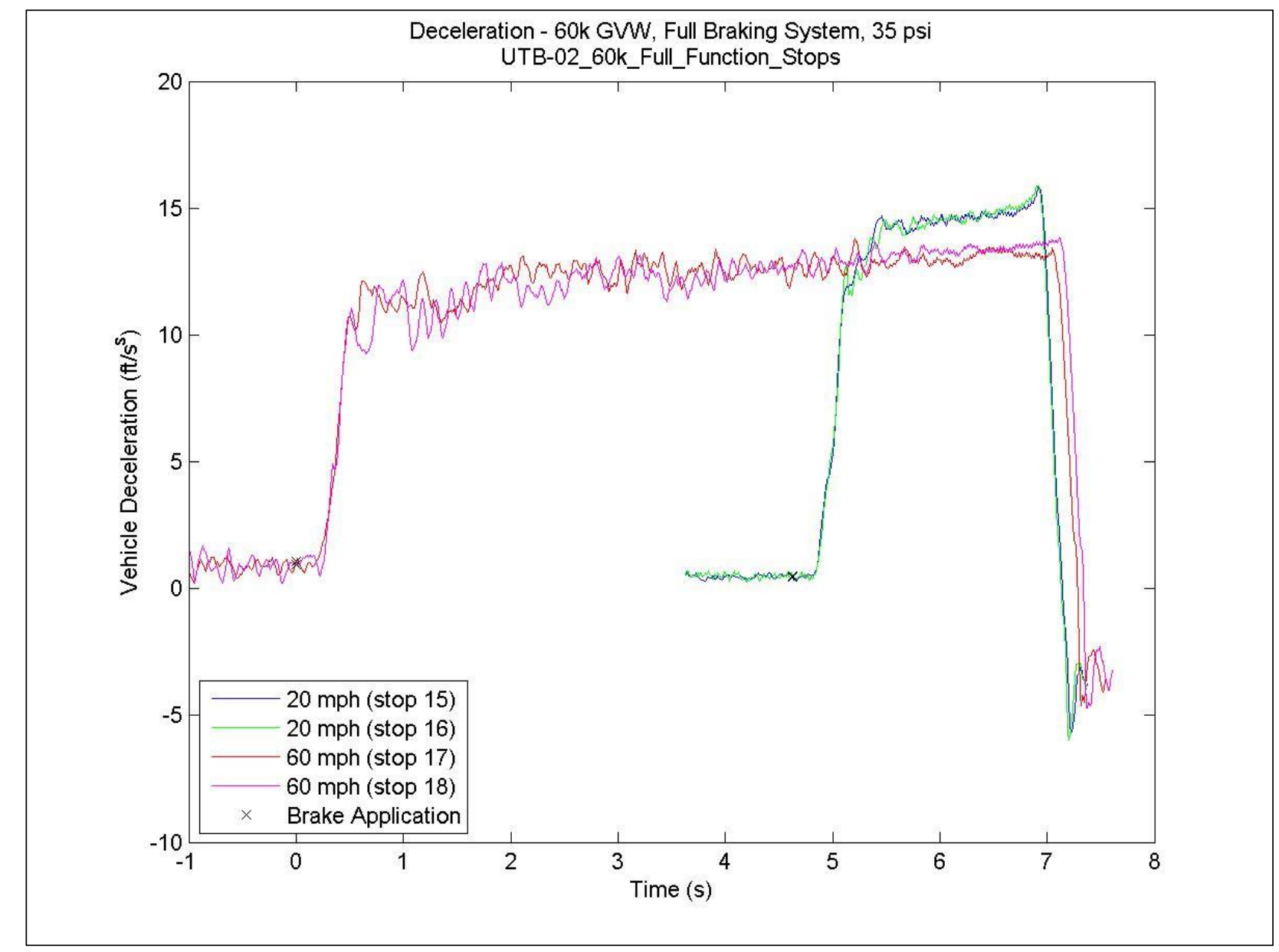

Figure 13. Comparison of sample deceleration profile for 20- and 60-mph constant-pressure stops.

\subsubsection{Effect of Loading}

Higher weight corresponds to lower deceleration as expected; based on Newton's second law, the deceleration of the vehicle for a given force (i.e., provided the effect of weight on braking force and drag is insignificant) is directly proportional to the mass. This was observed in both the 20 - and 60 -mph tests (Figure 14 and Figure 15 respectively, shown in the following section). 


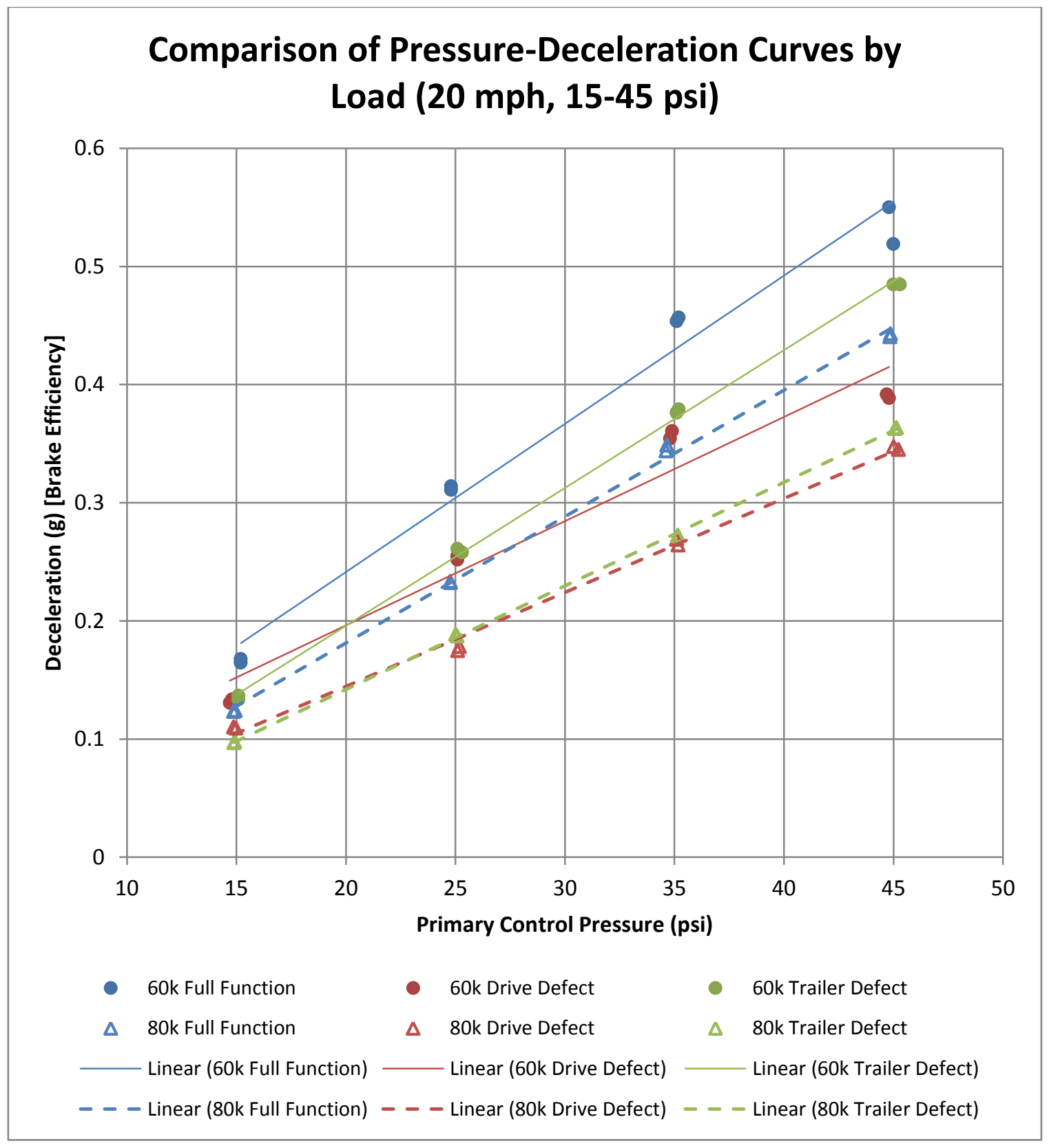

Figure 14. Pressure-deceleration curves by load and brake condition for $20 \mathrm{mph}$. 


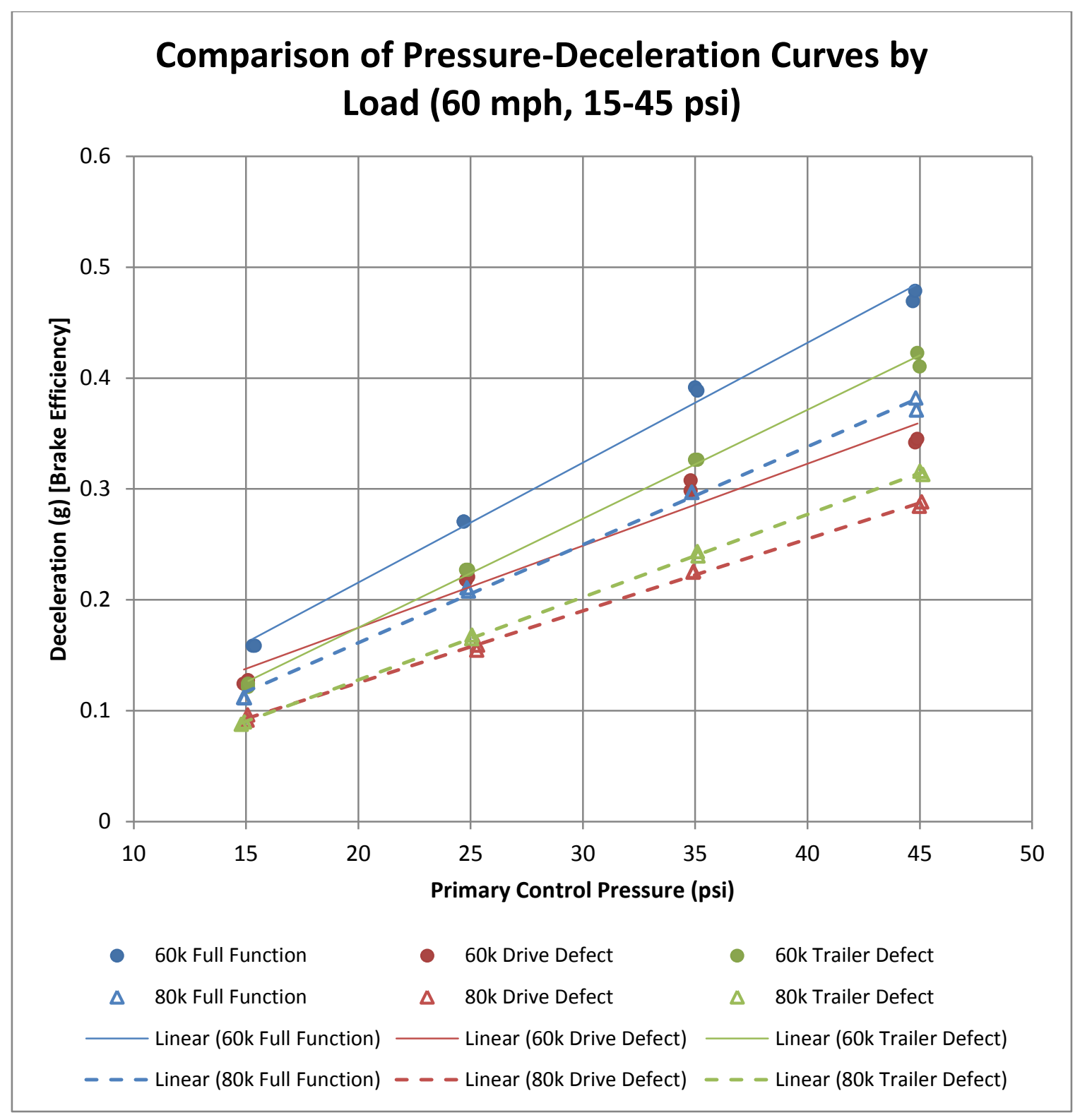

Figure 15. Pressure-deceleration curves by load and brake condition for $60 \mathrm{mph}$.

\subsubsection{Effect of Defect Position}

The position of the defective pair of brakes influenced the position of the pressure/deceleration line. As shown in Figure 14 and Figure 15, disabling drive axle brakes resulted in a poorer brake performance than disabling trailer brakes. This observation held for all four combinations of initial speed (20 and $60 \mathrm{mph}$ ) and loading condition (60,000-lb and 80,000-lb GVW).

\subsection{NORMALIZATION AND OBSERVATIONS}

Normalization equations were generated from full-function brake configuration only, and then applied to all data to determine how well the algorithm handles other data (the two disabled brake configurations). 
The basing of such an algorithm only on data from the fully-functioning configuration is analogous to calibrating an on-board brake monitoring system with several constant-pressure stops when the brakes were in good condition (in order to detect performance degradation at a later time).

The original pressure/deceleration data is shown in Figure 16. Note that data from full-function, disableddrive, and disabled-trailer braking conditions in the raw data set (not filtered by initial speed or GVW) overlap.

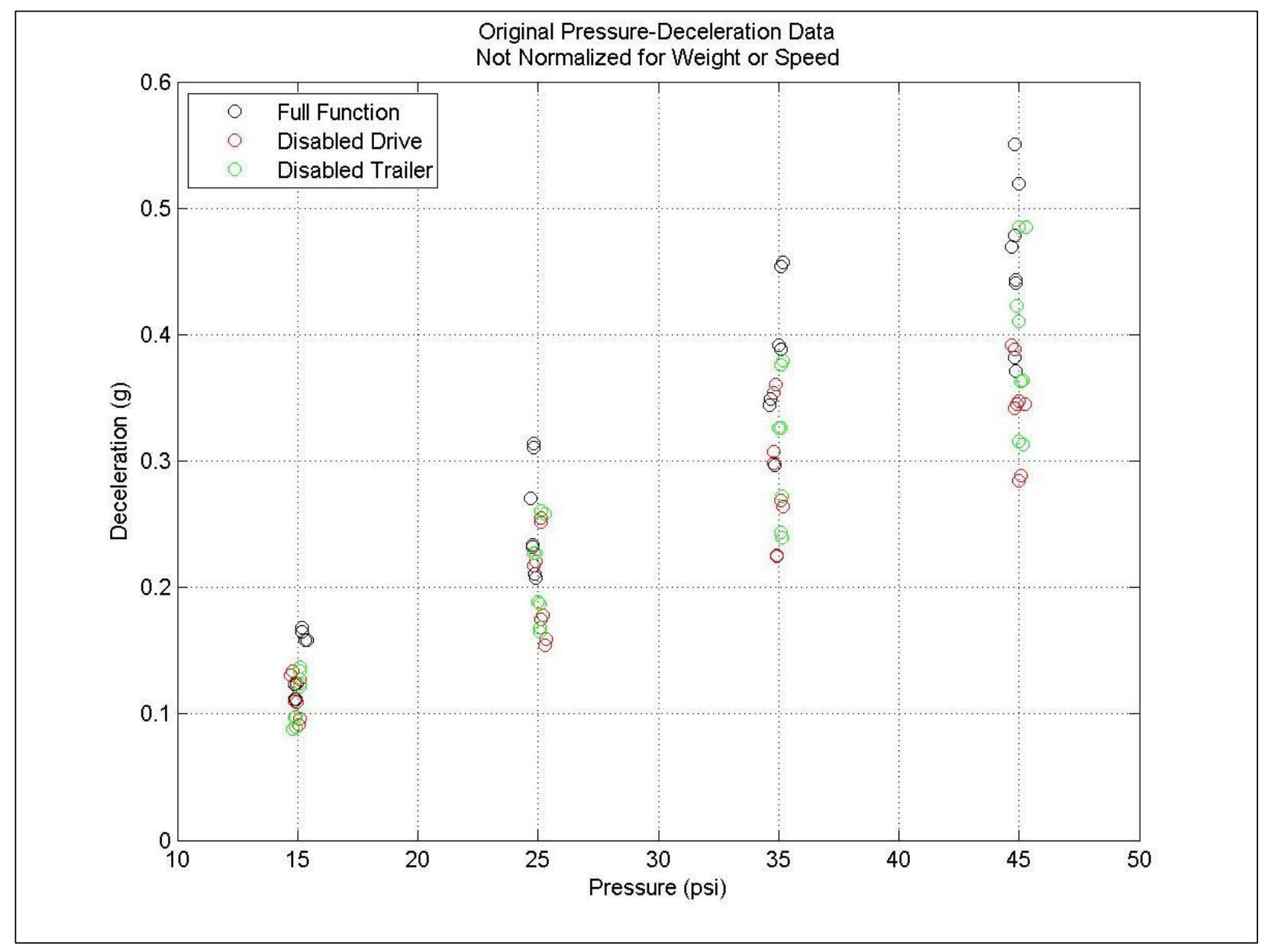

Figure 16. Original pressure-deceleration data before normalization.

\subsubsection{Normalizing for speed (to $20 \mathrm{mph}$ )}

Since only two speeds were tested, normalizing for speed was done by finding the relationship between equivalent 20- and 60-mph tests - stops performed under the same loading conditions and at the same brake application pressure. A plot of deceleration for the 20-mph runs as a function of that of the equivalent 60-mph runs (Figure 17) revealed a strong linear relationship between the two $\left(\mathrm{r}^{2}=0.99557\right)$. The regression line generated from the full-functioning brake system data was used to "convert" all 60mph deceleration data (including all loading conditions and brake conditions) into equivalent 20-mph decelerations: $d_{20 m p h}=1.178 * d_{60 m p h}-0.010154$. (While a simple linear correction was possible in this test data because only two speeds were tested, the relationship between speed and drag is more complex, with instantaneous drag proportional to instantaneous speed. The limited data collected in this testing was not conducive to the development of a more complex model able to handle a variety of speeds.) 


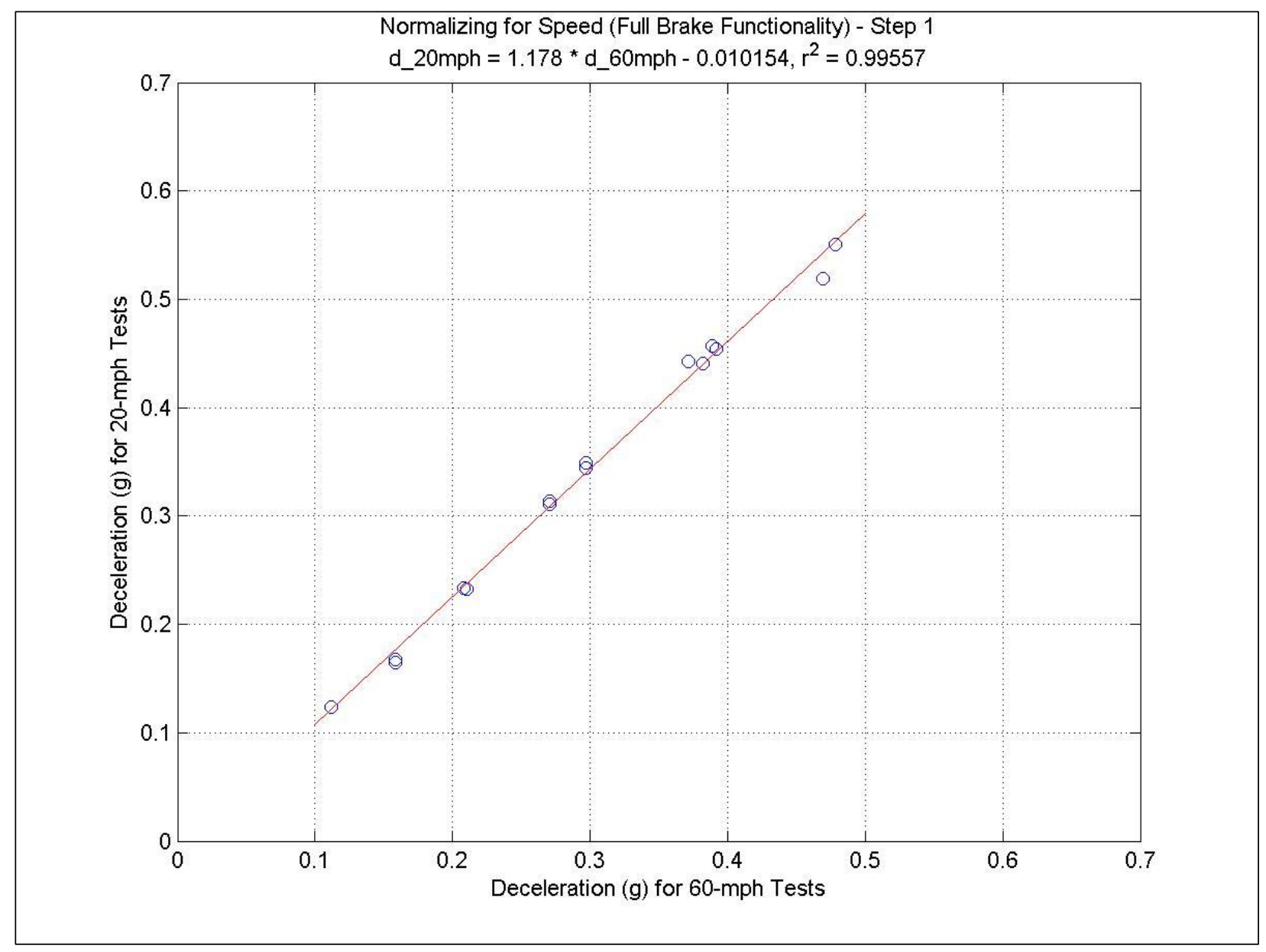

Figure 17. Full-function pressure-deceleration data normalized to 20-mph initial speed.

\subsubsection{Normalizing for weight (to $60,000 \mathrm{lb}$ )}

Next, the vehicles were normalized for weight to $60,000 \mathrm{lb}$ GVW. Deceleration for the $60,000 \mathrm{lb}$ runs was plotted as a function of corresponding 80,000-lb runs (Figure 18) and found to have a strong linear relationship $\left(\mathrm{r}^{2}=0.99119\right)$. The regression line generated from the full-brake-function runs $\left(d_{60 k}=1.1893 * d_{80 k}+0.030578\right)$ was used to "convert" all 80,000-lb decelerations to equivalent $60,000-1 \mathrm{~b}$ runs. 


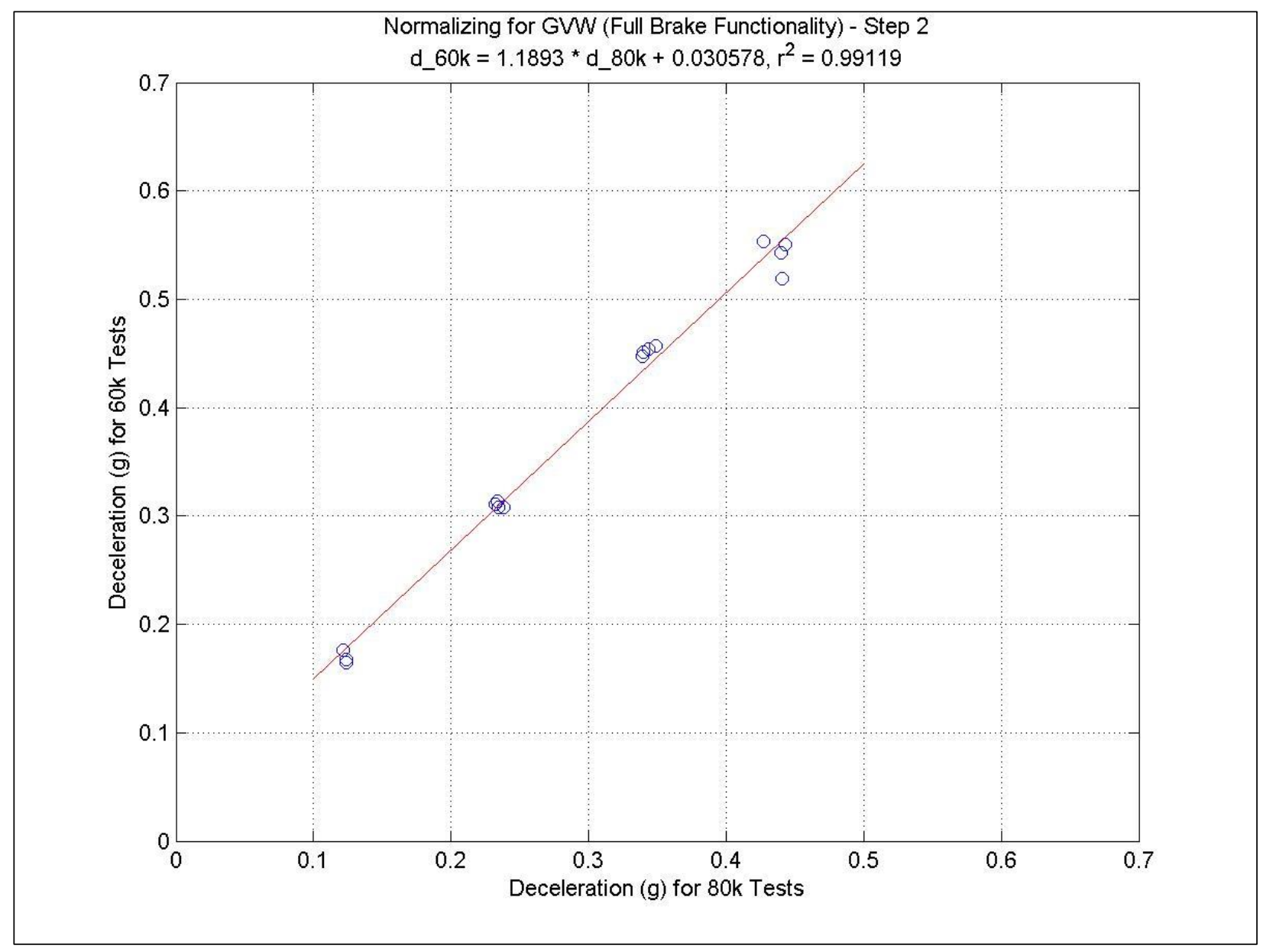

Figure 18. Full-function pressure-deceleration data normalized to 60,000-lb GVW load.

\subsubsection{Results of Data Normalization}

Once all the data was normalized to $20 \mathrm{mph}$ and 60,000 lb, the full-function values are tightly grouped along a line with all disabled brake tests falling clearly below the trendline for the fully-functioning brake system (Figure 19). 


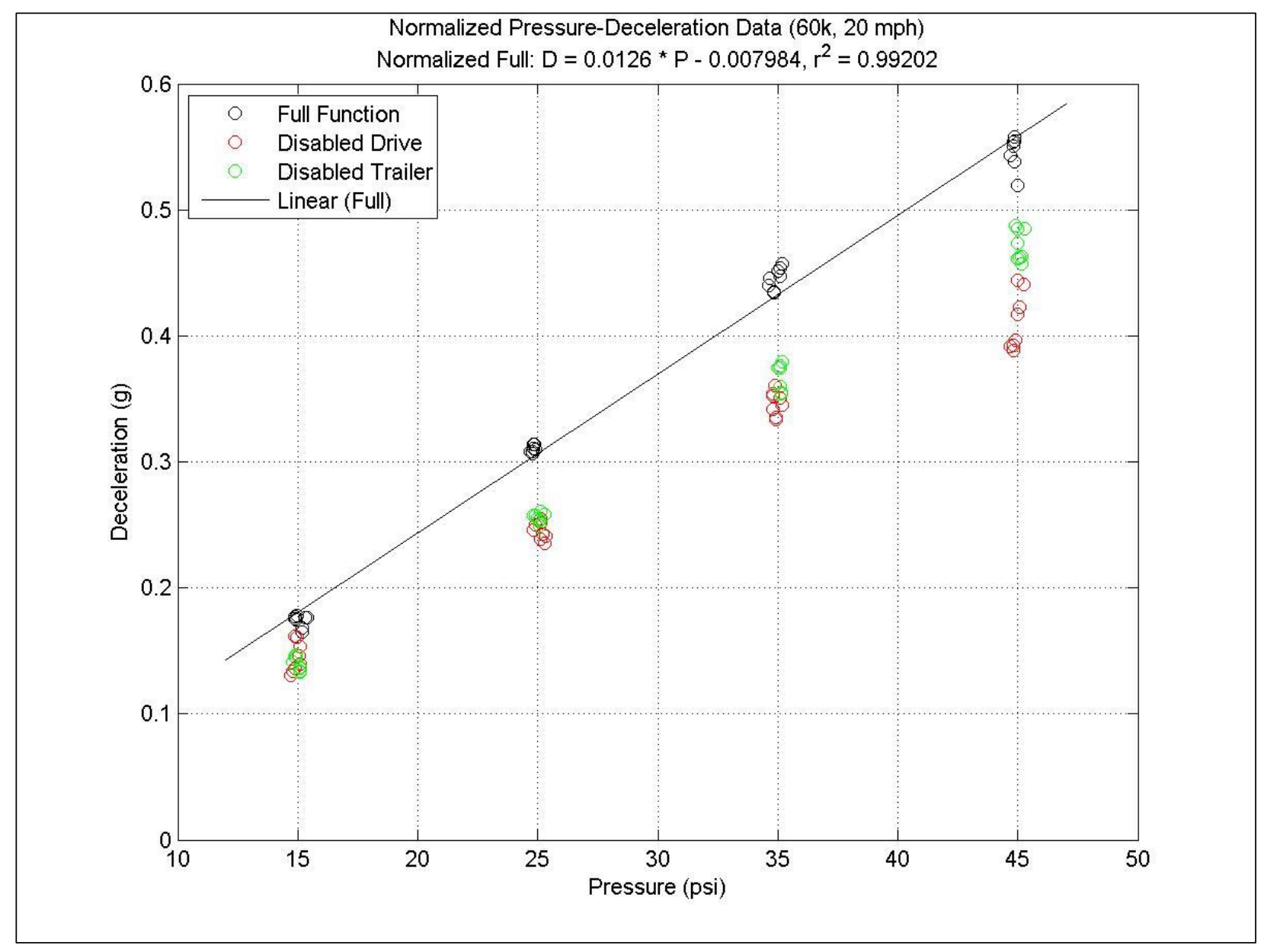

Figure 19. All pressure-deceleration data following normalization.

\subsection{SUMMARY OF NOVEL RESEARCH AND PROGRESS}

A simplified algorithm to normalize from 80,000-lb load to 60,000-lb load and from 60-mph to 20-mph initial speed was developed using data from the full-functioning brake system. When this algorithm was applied to the data from tests involving disabled brakes, it clearly fell below the Pressure-Deceleration trendline for fully-functioning data. In addition, the linear pressure-deceleration region was found to be consistent up through mid-range pressures (at least for this vehicle) with an upper limit of approximately 50 psi for the test vehicle. 


\section{LESSONS LEARNED}

As with any research and testing effort, certain lessons were learned which may provide guidance for future research of a similar nature.

\subsection{PROCUREMENT PROCESSES}

The project team took into account procurement processes when designing the test, involving personnel from ORNL procurement during the early stages of planning. This minimized the overall delay from test planning to actual testing. The challenges encountered during this test points to need for an adaptive procurement mechanism; in this testing, a brake failure occurred during the 97,000 lb loading tests. When testing vehicles in this type of environment, there need to be plans in place to react; in this case the contract needed to be modified before proceeding with the repairs to resume testing. As such, there should be a general goal of minimizing changes, although procurement processes need to support some changes as inevitable.

\subsection{CONSIDERATION OF TIRE LOAD CAPACITY}

Due to load positioning in these configurations, an overload condition was created for the rating of the tires available for testing. This should be addressed in future testing to avoid exceeding load ratings of all components, including tires.

\subsection{TIMING OF ANALYSIS COMPONENT}

In this testing effort, an initial data analysis was budgeted for, thus allowing for the validation of test signals and values early in the data collect. Additionally, the data was subject to low-level analysis as it came in during the entire testing period. This provided an opportunity to catch any missing or clearly erroneous data while testing could still be repeated. . This approach is recommended for future data collections to decrease the risk of invalid or lost data. Further, an ideal project plan would allow the entire analysis task to be conducted concurrently with data collection. 


\section{FUTURE DIRECTIONS}

This research revealed areas in which future research should focus in order to further develop and test an on-board brake assessment algorithm. Additional information needed to build a model includes intermediate speed(s). The correction factors for other speeds may be estimated from the relationship between drag and speed but should be confirmed using test data. It is suggested testing be performed at speeds such as $10 \mathrm{mph}, 20 \mathrm{mph}, 40 \mathrm{mph}$, and $60 \mathrm{mph}$. (Ideally, testing would be performed for two vehicles with different aerodynamic profiles. Data from the first vehicle would be used to fine-tune a simplified speed normalization algorithm. Then, looking at data from the second vehicle for only two speeds (e.g., 20 and $60 \mathrm{mph}$ ), a speed normalization algorithm unique to the second vehicle's aerodynamics would be generated. The actual test data from the remaining test speeds for that vehicle would be used to corroborate the model.)

While this research focused on the typical five-axle tractor-trailer vehicle with only two disabled-brake configurations (in addition to the fully-functioning system) to obtain a more complete picture of the vehicles on the roadway, testing should be expanded to other vehicle configurations such as straight trucks and six-axle combination trucks. Testing of vehicles meeting the older stopping distance requirements (currently more typical of vehicles currently on the roadways) may also provide a more complete picture of heavy vehicle braking capacities. 
APPENDIX A: SUMMARY OF STOPPING TEST RESULTS

\begin{tabular}{|c|c|c|c|c|c|c|c|c|c|c|c|c|c|c|}
\hline Filename & $\begin{array}{c}\text { Brakes } \\
\text { Disable } \\
\text { d }\end{array}$ & $\begin{array}{l}\text { Stop \# } \\
\text { (in } \\
\text { File) }\end{array}$ & $\begin{array}{l}\text { Target } \\
\text { Speed } \\
(\mathrm{mph})\end{array}$ & $\begin{array}{l}\text { Actual } \\
\text { Speed } \\
(\mathrm{mph})\end{array}$ & $\begin{array}{c}\text { Actual } \\
\text { Stop } \\
\text { Distance } \\
(\mathrm{ft})\end{array}$ & $\begin{array}{c}\text { Corrected } \\
\text { Stop } \\
\text { Distance } \\
\text { (ft) } \\
\end{array}$ & $\begin{array}{c}\text { Avg. } \\
\text { Primary } \\
\text { Control } \\
\text { Pressure } \\
\text { (psi) } \\
\end{array}$ & $\begin{array}{c}\text { Avg. } \\
\text { Secondar } \\
\text { y Control } \\
\text { Pressure } \\
\text { (psi) }\end{array}$ & $\begin{array}{l}\text { Avg. } \\
\text { Decel } \\
\text { (ft/s/s) }\end{array}$ & $\begin{array}{l}\text { Stop } \\
\text { Time } \\
\text { (sec) }\end{array}$ & $\begin{array}{c}\text { Steer } \\
\text { Axle } \\
\text { Weight } \\
\text { (lb) }\end{array}$ & $\begin{array}{c}\text { Drive } \\
\text { Tandem } \\
\text { Axles } \\
\text { Weight } \\
\text { (lb) } \\
\end{array}$ & $\begin{array}{c}\text { Trailer } \\
\text { Tandem } \\
\text { Axles } \\
\text { Weight } \\
\text { (lb) } \\
\end{array}$ & $\begin{array}{c}\text { Gross } \\
\text { Vehicle } \\
\text { Weight } \\
\text { (Ib) } \\
\end{array}$ \\
\hline UTB-02 Control Trailer Stops & None & 1 & 20 & 20.7 & 29.9 & 28 & 104.1 & 111.2 & 21.6 & 1.69 & 13340 & 38020 & 4500 & 55860 \\
\hline UTB-02 Control Trailer Stops & None & 2 & 20 & 20.8 & 29.1 & 27 & 106.4 & 112.9 & 20.4 & 1.68 & 13340 & 38020 & 4500 & 55860 \\
\hline UTB-02 Control Trailer Stops & None & 3 & 20 & 20.5 & 29.3 & 28 & 107.2 & 113 & 19.6 & 1.73 & 13340 & 38020 & 4500 & 55860 \\
\hline UTB-02 Control Trailer Stops & None & 4 & 60 & 60.7 & 232.6 & 227 & 101.1 & 112 & 18.8 & 4.99 & 13340 & 38020 & 4500 & 55860 \\
\hline UTB-02 Control Trailer Stops & None & 5 & 60 & 60.6 & 225.5 & 221 & 100.6 & 111.8 & 19.6 & 4.77 & 13340 & 38020 & 4500 & 55860 \\
\hline UTB-02 Control Trailer Stops & None & 6 & 60 & 60.3 & 229 & 227 & 100.6 & 111.7 & 19.5 & 4.81 & 13340 & 38020 & 4500 & 55860 \\
\hline UTB-02 Control Trailer Stops & $\begin{array}{l}\text { Front } \\
\text { Drive } \\
\end{array}$ & 7 & 20 & 20.8 & 47.6 & 44 & 106.4 & 107.8 & 11.1 & 2.94 & 13340 & 38020 & 4500 & 55860 \\
\hline UTB-02 Control Trailer Stops & $\begin{array}{l}\text { Front } \\
\text { Drive }\end{array}$ & 8 & 20 & 20.9 & 46.9 & 43 & 106.5 & 107.7 & 11.3 & 2.91 & 13340 & 38020 & 4500 & 55860 \\
\hline UTB-02 Control Trailer Stops & $\begin{array}{l}\text { Front } \\
\text { Drive } \\
\end{array}$ & 9 & 20 & 20.6 & 45.6 & 43 & 105.5 & 107.1 & 11.6 & 2.83 & 13340 & 38020 & 4500 & 55860 \\
\hline UTB-02 Control Trailer Stops & $\begin{array}{l}\text { Front } \\
\text { Drive } \\
\end{array}$ & 10 & 60 & 60.7 & 414.2 & 405 & 95.1 & 107.6 & 10.2 & 8.97 & 13340 & 38020 & 4500 & 55860 \\
\hline UTB-02 Control Trailer Stops & $\begin{array}{l}\text { Front } \\
\text { Drive }\end{array}$ & 11 & 60 & 60.5 & 410.4 & 404 & 93.9 & 106.9 & 10.1 & 8.97 & 13340 & 38020 & 4500 & 55860 \\
\hline UTB-02 Control Trailer Stops & $\begin{array}{l}\text { Front } \\
\text { Drive }\end{array}$ & 12 & 60 & 60.2 & 399.2 & 396 & 94.5 & 106 & 10.6 & 8.67 & 13340 & 38020 & 4500 & 55860 \\
\hline UTB-02_60k_Full_Function_Stops & None & 1 & 20 & 20.6 & 29.8 & 28.08936 & 107.7 & 107.7 & 19.4 & 1.7 & 12630 & 24490 & 22920 & 60040 \\
\hline UTB-02_60k_Full_Function_Stops & None & 2 & 20 & 20.5 & 29 & 27.60262 & 106.9 & 107.5 & 18.8 & 1.7 & 12630 & 24490 & 22920 & 60040 \\
\hline UTB-02_60k_Full_Function_Stops & None & 3 & 20 & 20.4 & 28.5 & 27.39331 & 106.4 & 106.6 & 19.2 & 1.7 & 12630 & 24490 & 22920 & 60040 \\
\hline UTB-02_60k_Full_Function_Stops & None & 4 & 60 & 60.3 & 221.4 & 219.2025 & 98.2 & 103.6 & 19.5 & 4.7 & 12630 & 24490 & 22920 & 60040 \\
\hline UTB-02_60k_Full_Function_Stops & None & 5 & 60 & 60.5 & 225.5 & 221.7881 & 101.2 & 105.7 & 19.7 & 4.7 & 12630 & 24490 & 22920 & 60040 \\
\hline UTB-02_60k_Full_Function_Stops & None & 6 & 60 & 60.4 & 239.9 & 236.733 & 103.3 & 107 & 18.7 & 4.9 & 12630 & 24490 & 22920 & 60040 \\
\hline UTB-02_60k_Full_Function_Stops & None & 7 & 20 & 20.4 & 90.5 & 86.98577 & 15.2 & 13.9 & 5.3 & 5.6 & 12630 & 24490 & 22920 & 60040 \\
\hline UTB-02_60k_Full_Function_Stops & None & 8 & 20 & 20.4 & 89.9 & 86.40907 & 15.2 & 13.8 & 5.4 & 5.6 & 12630 & 24490 & 22920 & 60040 \\
\hline UTB-02_60k_Full_Function_Stops & None & 9 & 60 & 60.2 & 777.7 & 772.5411 & 15.3 & 14 & 5.1 & 17.1 & 12630 & 24490 & 22920 & 60040 \\
\hline UTB-02_60k_Full_Function_Stops & None & 10 & 60 & 60.3 & 779.7 & 771.9611 & 15.4 & 14 & 5.1 & 17 & 12630 & 24490 & 22920 & 60040 \\
\hline UTB-02_60k_Full_Function_Stops & None & 11 & 20 & 20.4 & 51.8 & 49.78854 & 24.8 & 23.7 & 10.1 & 3.1 & 12630 & 24490 & 22920 & 60040 \\
\hline
\end{tabular}




\begin{tabular}{|c|c|c|c|c|c|c|c|c|c|c|c|c|c|c|}
\hline Filename & $\begin{array}{c}\text { Brakes } \\
\text { Disable } \\
\text { d }\end{array}$ & $\begin{array}{c}\text { Stop \# } \\
\text { (in } \\
\text { File) }\end{array}$ & $\begin{array}{l}\text { Target } \\
\text { Speed } \\
(\mathrm{mph})\end{array}$ & $\begin{array}{l}\text { Actual } \\
\text { Speed } \\
\text { (mph) }\end{array}$ & $\begin{array}{c}\text { Actual } \\
\text { Stop } \\
\text { Distance } \\
(\mathrm{ft})\end{array}$ & $\begin{array}{c}\text { Corrected } \\
\text { Stop } \\
\text { Distance } \\
(\mathrm{ft})\end{array}$ & $\begin{array}{c}\text { Avg. } \\
\text { Primary } \\
\text { Control } \\
\text { Pressure } \\
\text { (psi) } \\
\end{array}$ & $\begin{array}{c}\text { Avg. } \\
\text { Secondar } \\
\text { y Control } \\
\text { Pressure } \\
\text { (psi) }\end{array}$ & $\begin{array}{l}\text { Avg. } \\
\text { Decel } \\
\text { (ft/s/s) }\end{array}$ & $\begin{array}{l}\text { Stop } \\
\text { Time } \\
\text { (sec) }\end{array}$ & $\begin{array}{c}\text { Steer } \\
\text { Axle } \\
\text { Weight } \\
\text { (Ib) }\end{array}$ & $\begin{array}{l}\text { Drive } \\
\text { Tandem } \\
\text { Axles } \\
\text { Weight } \\
\text { (lb) } \\
\end{array}$ & $\begin{array}{c}\text { Trailer } \\
\text { Tandem } \\
\text { Axles } \\
\text { Weight } \\
\text { (lb) } \\
\end{array}$ & $\begin{array}{c}\text { Gross } \\
\text { Vehicle } \\
\text { Weight } \\
\text { (lb) } \\
\end{array}$ \\
\hline UTB-02_60k_Full_Function_Stops & None & 13 & 60 & 60.4 & 466.6 & 460.4403 & 24.7 & 23.8 & 8.7 & 10 & 12630 & 24490 & 22920 & 60040 \\
\hline UTB-02_60k_Full_Function_Stops & None & 14 & 60 & 60.2 & 457.1 & 454.0678 & 24.7 & 23.8 & 8.7 & 9.9 & 12630 & 24490 & 22920 & 60040 \\
\hline UTB-02_60k_Full_Function_Stops & None & 15 & 20 & 20.6 & 38.6 & 36.3842 & 35.1 & 33.8 & 14.6 & 2.3 & 12630 & 24490 & 22920 & 60040 \\
\hline UTB-02_60k_Full_Function_Stops & None & 16 & 20 & 20.4 & 331.6 & 318.7236 & 35.2 & 33.8 & 14.7 & 2.2 & 12630 & 24490 & 22920 & 60040 \\
\hline UTB-02_60k_Full_Function_Stops & None & 17 & 60 & 60.5 & 338.8 & 333.2231 & 35 & 33.9 & 12.6 & 7 & 12630 & 24490 & 22920 & 60040 \\
\hline UTB-02_60k_Full_Function_Stops & None & 18 & 60 & 60.3 & 33.9 & 33.56353 & 35.1 & 34.1 & 12.5 & 7.1 & 12630 & 24490 & 22920 & 60040 \\
\hline UTB-02_60k_Full_Function_Stops & None & 19 & 20 & 20.5 & 32.9 & 31.31469 & 45 & 44.6 & 16.7 & 2 & 12630 & 24490 & 22920 & 60040 \\
\hline UTB-02_60k_Full_Function_Stops & None & 20 & 20 & 20.5 & 32.9 & 31.31469 & 44.8 & 44.5 & 17.7 & 1.9 & 12630 & 24490 & 22920 & 60040 \\
\hline UTB-02_60k_Full_Function_Stops & None & 21 & 60 & 60.3 & 284.9 & 282.0722 & 44.7 & 44.5 & 15.1 & 5.9 & 12630 & 24490 & 22920 & 60040 \\
\hline UTB-02_60k_Full_Function_Stops & None & 22 & 60 & 60.2 & 286.3 & 284.4008 & 44.8 & 44.5 & 15.4 & 5.9 & 12630 & 24490 & 22920 & 60040 \\
\hline UTB-02_60k_Full_Function_Stops & None & 23 & 20 & 20.5 & 32 & 30.45806 & 55.6 & 55 & 16.9 & 1.9 & 12630 & 24490 & 22920 & 60040 \\
\hline UTB-02_60k_Full_Function_Stops & None & 25 & 60 & 60.1 & 270.5 & 269.6006 & 55.6 & 55.1 & 15.9 & 5.6 & 12630 & 24490 & 22920 & 60040 \\
\hline UTB-02_60k_Full_Function_Stops & None & 26 & 60 & 60.1 & 264.7 & 263.8199 & 55.1 & 55.2 & 16.4 & 5.5 & 12630 & 24490 & 22920 & 60040 \\
\hline $\begin{array}{l}\text { UTB- } \\
\text { 02_60k_Failed_Drive_Axle_Stops }\end{array}$ & $\begin{array}{l}\text { Front } \\
\text { Drive }\end{array}$ & 1 & 20 & 20.6 & 36.5 & 34.40475 & 110 & 108.3 & 14.6 & 2.2 & 12630 & 24490 & 22920 & 60040 \\
\hline $\begin{array}{l}\text { UTB- } \\
\text { 02_60k_Failed_Drive_Axle_Stops }\end{array}$ & $\begin{array}{l}\text { Front } \\
\text { Drive } \\
\end{array}$ & 2 & 20 & 20.7 & 36.4 & 33.97979 & 109.3 & 108.1 & 14.6 & 2.2 & 12630 & 24490 & 22920 & 60040 \\
\hline $\begin{array}{l}\text { UTB- } \\
\text { 02_60k_Failed_Drive_Axle_Stops }\end{array}$ & $\begin{array}{l}\text { Front } \\
\text { Drive }\end{array}$ & 3 & 20 & 20.6 & 35.7 & 33.65067 & 111.1 & 109 & 14.3 & 2.2 & 12630 & 24490 & 22920 & 60040 \\
\hline $\begin{array}{l}\text { UTB- } \\
\text { 02_60k_Failed_Drive_Axle_Stops }\end{array}$ & $\begin{array}{l}\text { Front } \\
\text { Drive } \\
\end{array}$ & 4 & 60 & 60.3 & 295.2 & 292.27 & 105.1 & 106.9 & 14 & 6.3 & 12630 & 24490 & 22920 & 60040 \\
\hline $\begin{array}{l}\text { UTB- } \\
\text { 02_60k_Failed_Drive_Axle_Stops }\end{array}$ & $\begin{array}{l}\text { Front } \\
\text { Drive } \\
\end{array}$ & 5 & 60 & 60.4 & 313 & 308.868 & 103.8 & 106.1 & 13.4 & 6.7 & 12630 & 24490 & 22920 & 60040 \\
\hline $\begin{array}{l}\text { UTB- } \\
\text { 02_60k_Failed_Drive_Axle_Stops }\end{array}$ & $\begin{array}{l}\text { Front } \\
\text { Drive } \\
\end{array}$ & 6 & 60 & 60.3 & 299 & 296.0323 & 104.1 & 105.7 & 13.9 & 6.4 & 12630 & 24490 & 22920 & 60040 \\
\hline $\begin{array}{l}\text { UTB- } \\
\text { 02_60k_Failed_Drive_Axle_Stops }\end{array}$ & $\begin{array}{l}\text { Front } \\
\text { Drive }\end{array}$ & 7 & 20 & 20.6 & 112 & 105.5707 & 14.7 & 13.3 & 4.2 & 7 & 12630 & 24490 & 22920 & 60040 \\
\hline $\begin{array}{l}\text { UTB- } \\
\text { 02_60k_Failed_Drive_Axle_Stops }\end{array}$ & $\begin{array}{l}\text { Front } \\
\text { Drive }\end{array}$ & 8 & 20 & 20.5 & 109.2 & 103.9381 & 14.8 & 13.5 & 4.3 & 6.8 & 12630 & 24490 & 22920 & 60040 \\
\hline $\begin{array}{l}\text { UTB- } \\
\text { 02_60k_Failed_Drive_Axle_Stops }\end{array}$ & $\begin{array}{l}\text { Front } \\
\text { Drive }\end{array}$ & 10 & 60 & 60.4 & 925.5 & 913.2823 & 15.1 & 13.6 & 4.1 & 20.5 & 12630 & 24490 & 22920 & 60040 \\
\hline
\end{tabular}




\begin{tabular}{|c|c|c|c|c|c|c|c|c|c|c|c|c|c|c|}
\hline Filename & $\begin{array}{c}\text { Brakes } \\
\text { Disable } \\
\text { d }\end{array}$ & $\begin{array}{l}\text { Stop \# } \\
\text { (in } \\
\text { File) }\end{array}$ & $\begin{array}{l}\text { Target } \\
\text { Speed } \\
(\mathrm{mph})\end{array}$ & $\begin{array}{l}\text { Actual } \\
\text { Speed } \\
\text { (mph) }\end{array}$ & $\begin{array}{c}\text { Actual } \\
\text { Stop } \\
\text { Distance } \\
\text { (ft) }\end{array}$ & $\begin{array}{c}\text { Corrected } \\
\text { Stop } \\
\text { Distance } \\
\text { (ft) } \\
\end{array}$ & $\begin{array}{c}\text { Avg. } \\
\text { Primary } \\
\text { Control } \\
\text { Pressure } \\
\text { (psi) } \\
\end{array}$ & $\begin{array}{c}\text { Avg. } \\
\text { Secondar } \\
\text { y Control } \\
\text { Pressure } \\
\text { (psi) }\end{array}$ & $\begin{array}{l}\text { Avg. } \\
\text { Decel } \\
\text { (ft/s/s) }\end{array}$ & $\begin{array}{l}\text { Stop } \\
\text { Time } \\
\text { (sec) }\end{array}$ & $\begin{array}{c}\text { Steer } \\
\text { Axle } \\
\text { Weight } \\
\text { (lb) }\end{array}$ & $\begin{array}{c}\text { Drive } \\
\text { Tandem } \\
\text { Axles } \\
\text { Weight } \\
\text { (lb) } \\
\end{array}$ & $\begin{array}{c}\text { Trailer } \\
\text { Tandem } \\
\text { Axles } \\
\text { Weight } \\
\text { (lb) } \\
\end{array}$ & $\begin{array}{c}\text { Gross } \\
\text { Vehicle } \\
\text { Weight } \\
\text { (Ib) }\end{array}$ \\
\hline $\begin{array}{l}\text { UTB- } \\
\text { 02_60k_Failed_Drive_Axle_Stops }\end{array}$ & $\begin{array}{l}\text { Front } \\
\text { Drive } \\
\end{array}$ & 11 & 20 & 20.4 & 61.7 & 59.30411 & 25.1 & 23.8 & 8.1 & 3.8 & 12630 & 24490 & 22920 & 60040 \\
\hline $\begin{array}{l}\text { UTB- } \\
02 \_60 \mathrm{k} \text { Failed_Drive_Axle_Stops }\end{array}$ & $\begin{array}{l}\text { Front } \\
\text { Drive } \\
\end{array}$ & 12 & 20 & 20.6 & 62.1 & 58.53521 & 25.1 & 24 & 8.2 & 3.8 & 12630 & 24490 & 22920 & 60040 \\
\hline $\begin{array}{l}\text { UTB- } \\
\text { 02_60k_Failed_Drive_Axle_Stops }\end{array}$ & $\begin{array}{l}\text { Front } \\
\text { Drive } \\
\end{array}$ & 13 & 60 & 60.4 & 559.3 & 551.9166 & 24.8 & 24 & 7 & 12.3 & 12630 & 24490 & 22920 & 60040 \\
\hline $\begin{array}{l}\text { UTB- } \\
\text { 02_60k_Failed_Drive_Axle_Stops }\end{array}$ & $\begin{array}{l}\text { Front } \\
\text { Drive } \\
\end{array}$ & 14 & 60 & 60.2 & 549.4 & 545.7556 & 24.9 & 24.1 & 7.1 & 12.1 & 12630 & 24490 & 22920 & 60040 \\
\hline $\begin{array}{l}\text { UTB- } \\
\text { 02_60k_Failed_Drive_Axle_Stops }\end{array}$ & $\begin{array}{l}\text { Front } \\
\text { Drive } \\
\end{array}$ & 15 & 20 & 20.2 & 45.4 & 44.50544 & 34.8 & 33.7 & 11.4 & 2.8 & 12630 & 24490 & 22920 & 60040 \\
\hline $\begin{array}{l}\text { UTB- } \\
\text { 02_60k_Failed_Drive_Axle_Stops }\end{array}$ & $\begin{array}{l}\text { Front } \\
\text { Drive }\end{array}$ & 16 & 20 & 20.2 & 45.6 & 44.7015 & 34.9 & 33.8 & 11.6 & 2.7 & 12630 & 24490 & 22920 & 60040 \\
\hline $\begin{array}{l}\text { UTB- } \\
\text { 02_60k_Failed_Drive_Axle_Stops }\end{array}$ & $\begin{array}{l}\text { Front } \\
\text { Drive } \\
\end{array}$ & 17 & 60 & 60.3 & 435.2 & 430.8804 & 34.8 & 33.9 & 9.6 & 9.2 & 12630 & 24490 & 22920 & 60040 \\
\hline $\begin{array}{l}\text { UTB- } \\
\text { 02_60k_Failed_Drive_Axle_Stops }\end{array}$ & $\begin{array}{l}\text { Front } \\
\text { Drive } \\
\end{array}$ & 19 & 20 & 20.3 & 40.9 & 39.70007 & 44.8 & 44.2 & 12.5 & 2.5 & 12630 & 24490 & 22920 & 60040 \\
\hline $\begin{array}{l}\text { UTB- } \\
\text { 02_60k_Failed_Drive_Axle_Stops }\end{array}$ & $\begin{array}{l}\text { Front } \\
\text { Drive }\end{array}$ & 20 & 20 & 20.2 & 41.9 & 41.0744 & 44.7 & 44.3 & 12.6 & 2.5 & 12630 & 24490 & 22920 & 60040 \\
\hline $\begin{array}{l}\text { UTB- } \\
\text { 02_60k_Failed_Drive_Axle_Stops }\end{array}$ & $\begin{array}{l}\text { Front } \\
\text { Drive }\end{array}$ & 21 & 60 & 60.1 & 380.6 & 379.3345 & 44.8 & 44.2 & 11 & 7.9 & 12630 & 24490 & 22920 & 60040 \\
\hline $\begin{array}{l}\text { UTB- } \\
\text { 02_60k_Failed_Drive_Axle_Stops }\end{array}$ & $\begin{array}{l}\text { Front } \\
\text { Drive } \\
\end{array}$ & 22 & 60 & 60.4 & 386.4 & 381.2991 & 44.9 & 44.3 & 11.1 & 8 & 12630 & 24490 & 22920 & 60040 \\
\hline $\begin{array}{l}\text { UTB- } \\
\text { 02_60k_Failed_Drive_Axle_Stops }\end{array}$ & $\begin{array}{l}\text { Front } \\
\text { Drive } \\
\end{array}$ & 23 & 20 & 20.2 & 41.4 & 40.58426 & 54.9 & 54.5 & 12.8 & 2.5 & 12630 & 24490 & 22920 & 60040 \\
\hline $\begin{array}{l}\text { UTB- } \\
\text { 02_60k_Failed_Drive_Axle_Stops }\end{array}$ & $\begin{array}{l}\text { Front } \\
\text { Drive } \\
\end{array}$ & 24 & 20 & 20.3 & 40.2 & 39.0206 & 55 & 54.5 & 12.9 & 2.4 & 12630 & 24490 & 22920 & 60040 \\
\hline $\begin{array}{l}\text { UTB- } \\
\text { 02_60k_Failed_Drive_Axle_Stops }\end{array}$ & $\begin{array}{l}\text { Front } \\
\text { Drive } \\
\end{array}$ & 25 & 60 & 60.3 & 370.2 & 366.5256 & 55.2 & 54.9 & 11.2 & 7.8 & 12630 & 24490 & 22920 & 60040 \\
\hline $\begin{array}{l}\text { UTB- } \\
\text { 02_60k_Failed_Drive_Axle_Stops }\end{array}$ & $\begin{array}{l}\text { Front } \\
\text { Drive }\end{array}$ & 26 & 60 & 60.1 & 364.8 & 363.587 & 55 & 54.8 & 11.5 & 7.7 & 12630 & 24490 & 22920 & 60040 \\
\hline $\begin{array}{l}\text { UTB- } \\
\text { 02_60k_Failed_Trailer_Axle_Stop } \\
\text { s }\end{array}$ & $\begin{array}{l}\text { Rear } \\
\text { Trailer }\end{array}$ & 1 & 20 & 20.3 & 29.3 & 28.44039 & 110.6 & 110.6 & 17.9 & 1.8 & 12630 & 24490 & 22920 & 60040 \\
\hline $\begin{array}{l}\text { UTB- } \\
\text { 02_60k_Failed_Trailer_Axle_Stop } \\
\text { s }\end{array}$ & $\begin{array}{l}\text { Rear } \\
\text { Trailer }\end{array}$ & 2 & 20 & 20.2 & 30.2 & 29.60494 & 110 & 110.7 & 16.6 & 1.9 & 12630 & 24490 & 22920 & 60040 \\
\hline
\end{tabular}




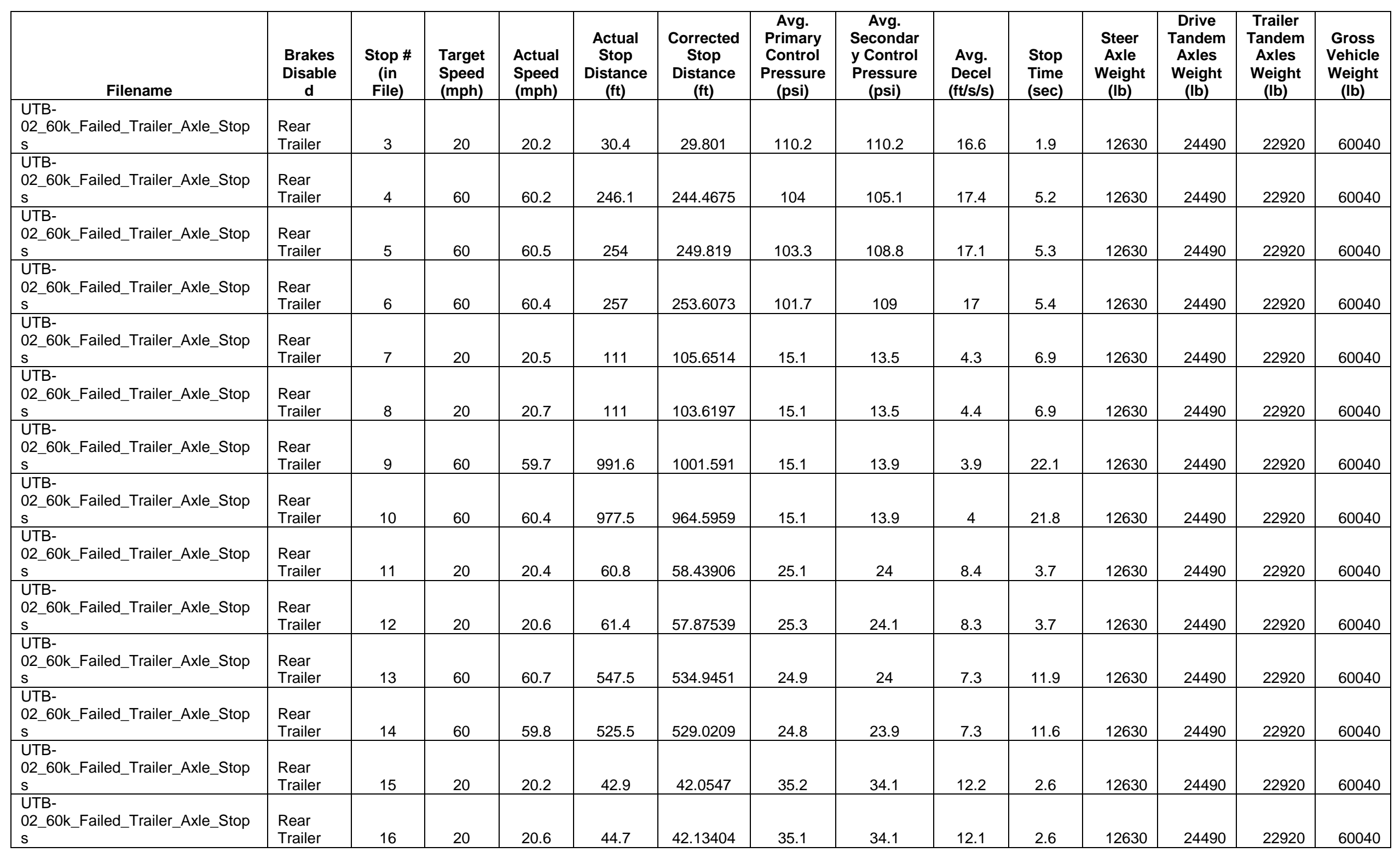




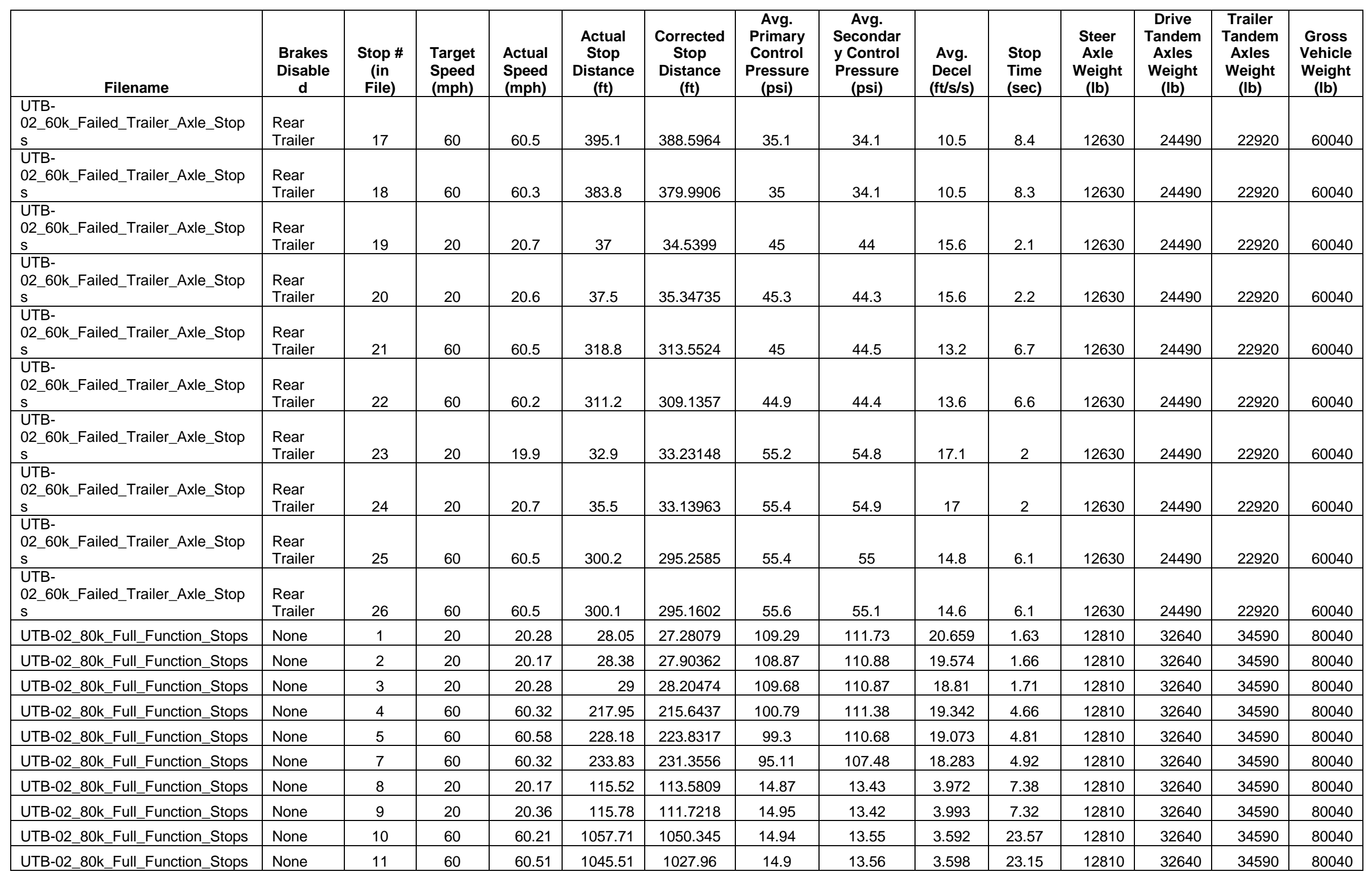




\begin{tabular}{|c|c|c|c|c|c|c|c|c|c|c|c|c|c|c|}
\hline Filename & $\begin{array}{c}\text { Brakes } \\
\text { Disable } \\
\text { d }\end{array}$ & $\begin{array}{l}\text { Stop \# } \\
\text { (in } \\
\text { File) }\end{array}$ & $\begin{array}{l}\text { Target } \\
\text { Speed } \\
(\mathrm{mph})\end{array}$ & $\begin{array}{l}\text { Actual } \\
\text { Speed } \\
\text { (mph) }\end{array}$ & $\begin{array}{c}\text { Actual } \\
\text { Stop } \\
\text { Distance } \\
(\mathrm{ft})\end{array}$ & $\begin{array}{c}\text { Corrected } \\
\text { Stop } \\
\text { Distance } \\
\text { (ft) }\end{array}$ & $\begin{array}{c}\text { Avg. } \\
\text { Primary } \\
\text { Control } \\
\text { Pressure } \\
\text { (psi) } \\
\end{array}$ & $\begin{array}{c}\text { Avg. } \\
\text { Secondar } \\
\text { y Control } \\
\text { Pressure } \\
\text { (psi) } \\
\end{array}$ & $\begin{array}{l}\text { Avg. } \\
\text { Decel } \\
\text { (ft/s/s) }\end{array}$ & $\begin{array}{l}\text { Stop } \\
\text { Time } \\
\text { (sec) }\end{array}$ & $\begin{array}{c}\text { Steer } \\
\text { Axle } \\
\text { Weight } \\
\text { (lb) }\end{array}$ & $\begin{array}{l}\text { Drive } \\
\text { Tandem } \\
\text { Axles } \\
\text { Weight } \\
\text { (lb) } \\
\end{array}$ & $\begin{array}{c}\text { Trailer } \\
\text { Tandem } \\
\text { Axles } \\
\text { Weight } \\
\text { (lb) } \\
\end{array}$ & $\begin{array}{c}\text { Gross } \\
\text { Vehicle } \\
\text { Weight } \\
\text { (lb) } \\
\end{array}$ \\
\hline UTB-02_80k_Full_Function_Stops & None & 12 & 20 & 20.32 & 63.75 & 61.75794 & 24.76 & 23.79 & 7.511 & 3.97 & 12810 & 32640 & 34590 & 80040 \\
\hline UTB-02_80k_Full_Function_Stops & None & 13 & 20 & 20.32 & 63.91 & 61.91294 & 24.78 & 23.83 & 7.475 & 3.97 & 12810 & 32640 & 34590 & 80040 \\
\hline UTB-02_80k_Full_Function_Stops & None & 14 & 60 & 60.06 & 574.15 & 573.0034 & 24.91 & 24.2 & 6.684 & 12.66 & 12810 & 32640 & 34590 & 80040 \\
\hline UTB-02_80k_Full_Function_Stops & None & 15 & 60 & 60.25 & 567.75 & 563.0482 & 24.85 & 24.22 & 6.779 & 12.49 & 12810 & 32640 & 34590 & 80040 \\
\hline UTB-02_80k_Full_Function_Stops & None & 16 & 20 & 20.24 & 46.59 & 45.49165 & 34.62 & 33.63 & 11.067 & 2.82 & 12810 & 32640 & 34590 & 80040 \\
\hline UTB-02_80k_Full_Function_Stops & None & 17 & 20 & 20.32 & 46.39 & 44.9404 & 34.66 & 33.68 & 11.22 & 2.79 & 12810 & 32640 & 34590 & 80040 \\
\hline UTB-02_80k_Full_Function_Stops & None & 18 & 60 & 60.17 & 410.14 & 407.8257 & 34.86 & 33.94 & 9.56 & 8.99 & 12810 & 32640 & 34590 & 80040 \\
\hline UTB-02_80k_Full_Function_Stops & None & 19 & 60 & 60.21 & 414.5 & 411.6137 & 34.86 & 33.95 & 9.545 & 9.05 & 12810 & 32640 & 34590 & 80040 \\
\hline UTB-02_80k_Full_Function_Stops & None & 20 & 20 & 20.13 & 38.39 & 37.89575 & 44.84 & 44.36 & 14.175 & 2.28 & 12810 & 32640 & 34590 & 80040 \\
\hline UTB-02_80k_Full_Function_Stops & None & 21 & 20 & 20.24 & 38.75 & 37.83648 & 44.87 & 44.4 & 14.254 & 2.29 & 12810 & 32640 & 34590 & 80040 \\
\hline UTB-02_80k_Full_Function_Stops & None & 22 & 60 & 60.51 & 335.3 & 329.6718 & 44.83 & 44.47 & 12.289 & 7.19 & 12810 & 32640 & 34590 & 80040 \\
\hline UTB-02_80k_Full_Function_Stops & None & 23 & 60 & 60.66 & 350.03 & 342.4546 & 44.85 & 44.53 & 11.941 & 7.41 & 12810 & 32640 & 34590 & 80040 \\
\hline UTB-02_80k_Full_Function_Stops & None & 25 & 20 & 20.43 & 34.68 & 33.23551 & 54.84 & 54.47 & 16.624 & 2 & 12810 & 32640 & 34590 & 80040 \\
\hline UTB-02_80k_Full_Function_Stops & None & 26 & 60 & 60.14 & 286.71 & 285.3767 & 54.98 & 54.63 & 14.686 & 6.04 & 12810 & 32640 & 34590 & 80040 \\
\hline UTB-02_80k_Full_Function_Stops & None & 27 & 60 & 60.4 & 295.08 & 291.1846 & 55.03 & 54.75 & 14.744 & 6.14 & 12810 & 32640 & 34590 & 80040 \\
\hline $\begin{array}{l}\text { UTB- } \\
\text { 02_80k_Failed_Drive_Axle_Stops }\end{array}$ & $\begin{array}{l}\text { Front } \\
\text { Drive }\end{array}$ & 7 & 20 & 20.54 & 36.15 & 34.27421 & 106.9 & 106.21 & 14.38 & 2.18 & 12810 & 32640 & 34590 & 80040 \\
\hline $\begin{array}{l}\text { UTB- } \\
02 \text { 00k_Failed_Drive_Axle_Stops }\end{array}$ & $\begin{array}{l}\text { Front } \\
\text { Drive } \\
\end{array}$ & 8 & 20 & 20.69 & 37.14 & 34.70411 & 106.6 & 105.62 & 13.906 & 2.24 & 12810 & 32640 & 34590 & 80040 \\
\hline $\begin{array}{l}\text { UTB- } \\
\text { 02_80k_Failed_Drive_Axle_Stops }\end{array}$ & $\begin{array}{l}\text { Front } \\
\text { Drive }\end{array}$ & 9 & 20 & 21.18 & 38.75 & 34.55252 & 105.07 & 104.98 & 13.906 & 2.29 & 12810 & 32640 & 34590 & 80040 \\
\hline $\begin{array}{l}\text { UTB- } \\
02 \_80 \mathrm{k} \text { Failed_Drive_Axle_Stops }\end{array}$ & $\begin{array}{l}\text { Front } \\
\text { Drive }\end{array}$ & 10 & 60 & 60.43 & 319.52 & 314.989 & 100.71 & 104.17 & 12.763 & 6.86 & 12810 & 32640 & 34590 & 80040 \\
\hline $\begin{array}{l}\text { UTB- } \\
02 \_80 k \text { Failed_Drive_Axle_Stops }\end{array}$ & $\begin{array}{l}\text { Front } \\
\text { Drive }\end{array}$ & 11 & 60 & 60.43 & 312.37 & 307.9404 & 100.2 & 103.05 & 13.169 & 6.73 & 12810 & 32640 & 34590 & 80040 \\
\hline $\begin{array}{l}\text { UTB- } \\
02 \text { 80k_Failed_Drive_Axle_Stops }\end{array}$ & $\begin{array}{l}\text { Front } \\
\text { Drive }\end{array}$ & 12 & 60 & 60.14 & 306.33 & 304.9054 & 98.25 & 102.51 & 13.121 & 6.67 & 12810 & 32640 & 34590 & 80040 \\
\hline $\begin{array}{l}\text { UTB- } \\
\text { 02_80k_Failed_Drive_Axle_Stops }\end{array}$ & $\begin{array}{l}\text { Front } \\
\text { Drive }\end{array}$ & 1 & 20 & 20.54 & 131.36 & 124.5438 & 14.87 & 13.84 & 3.55 & 8.34 & 12810 & 32640 & 34590 & 80040 \\
\hline $\begin{array}{l}\text { UTB- } \\
02 \text { 80k Failed Drive Axle Stops }\end{array}$ & $\begin{array}{l}\text { Front } \\
\text { Drive }\end{array}$ & 4 & 60 & 60.55 & 1291.96 & 1268.596 & 15.05 & 14.26 & 2.939 & 28.88 & 12810 & 32640 & 34590 & 80040 \\
\hline
\end{tabular}




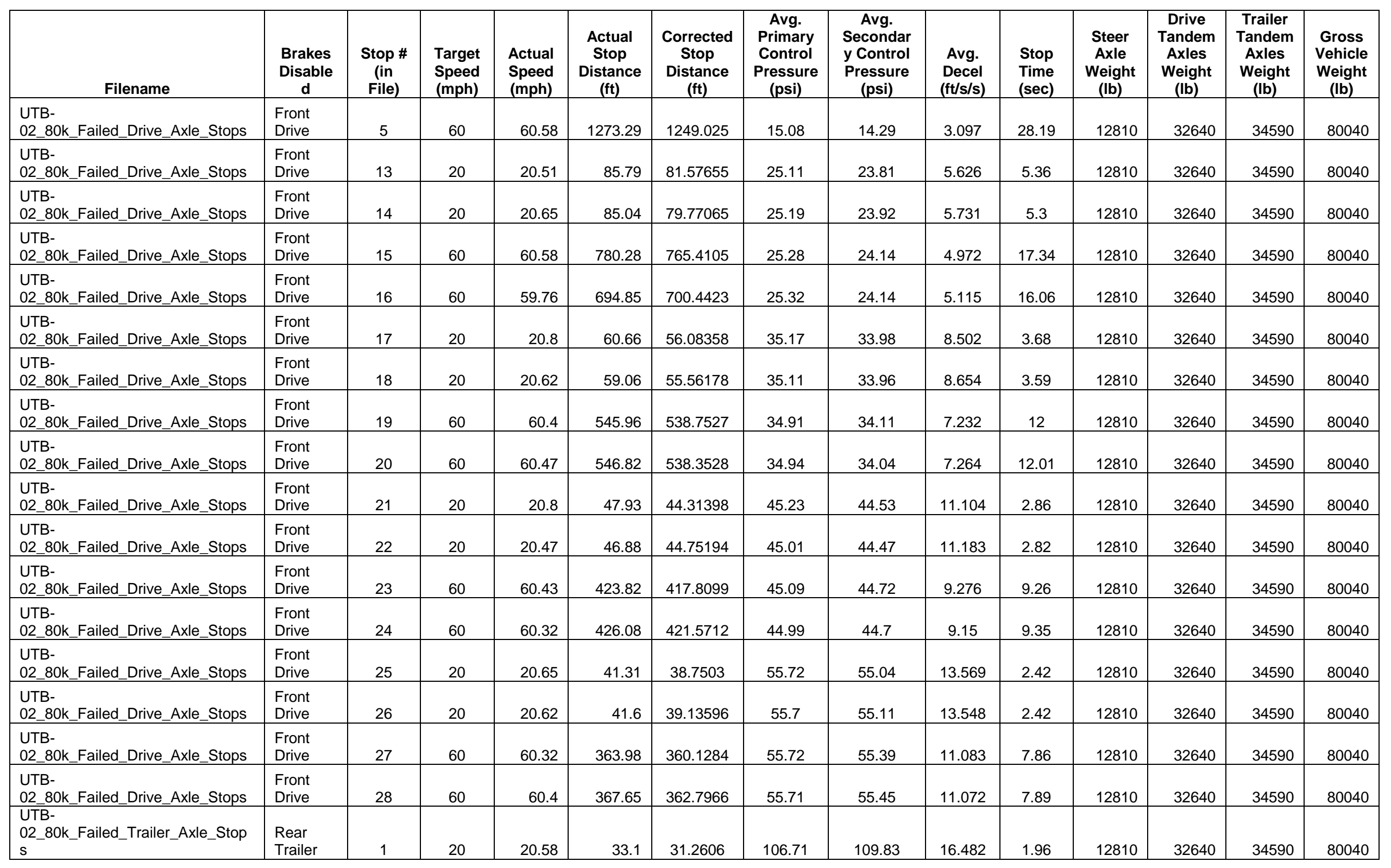




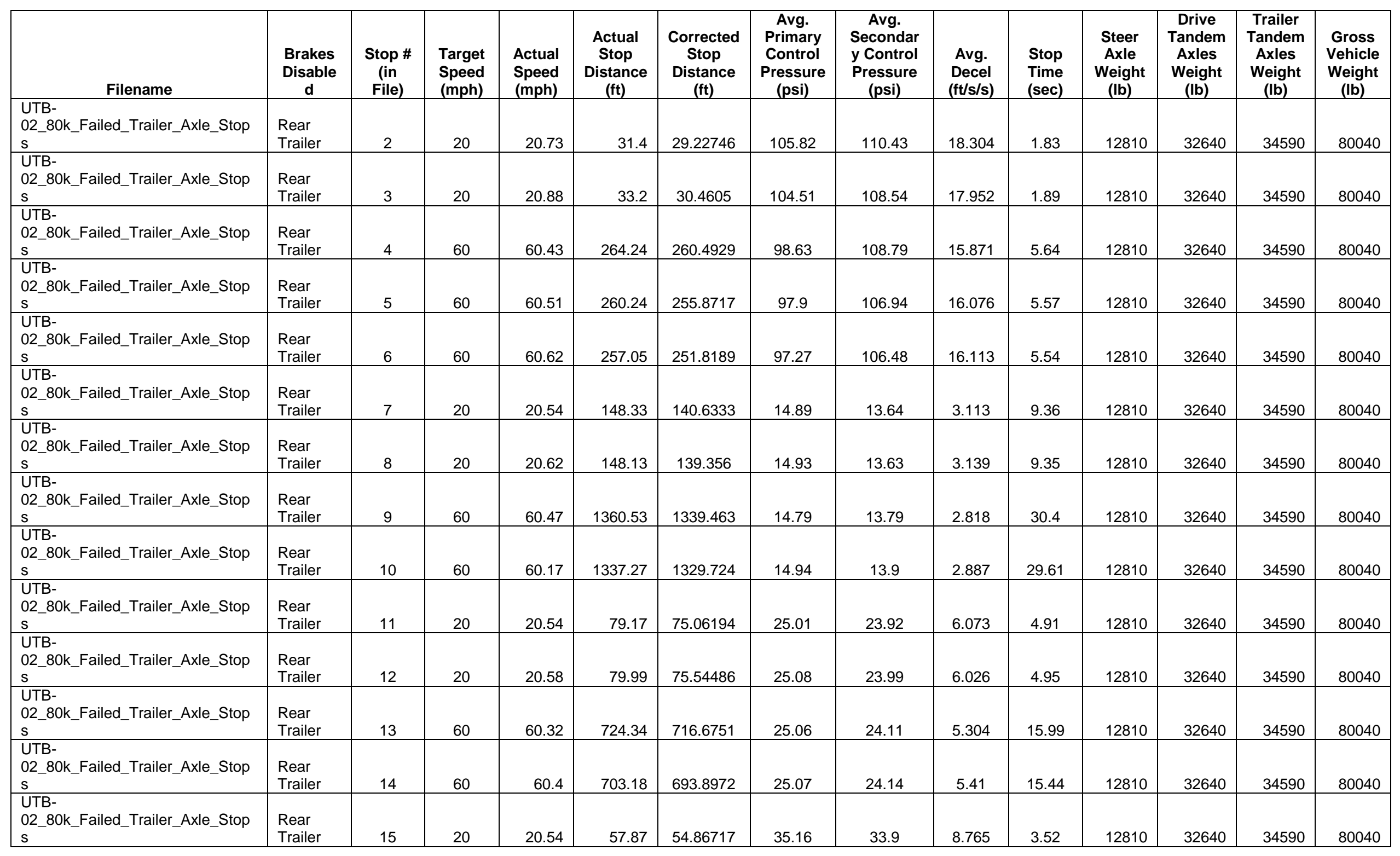




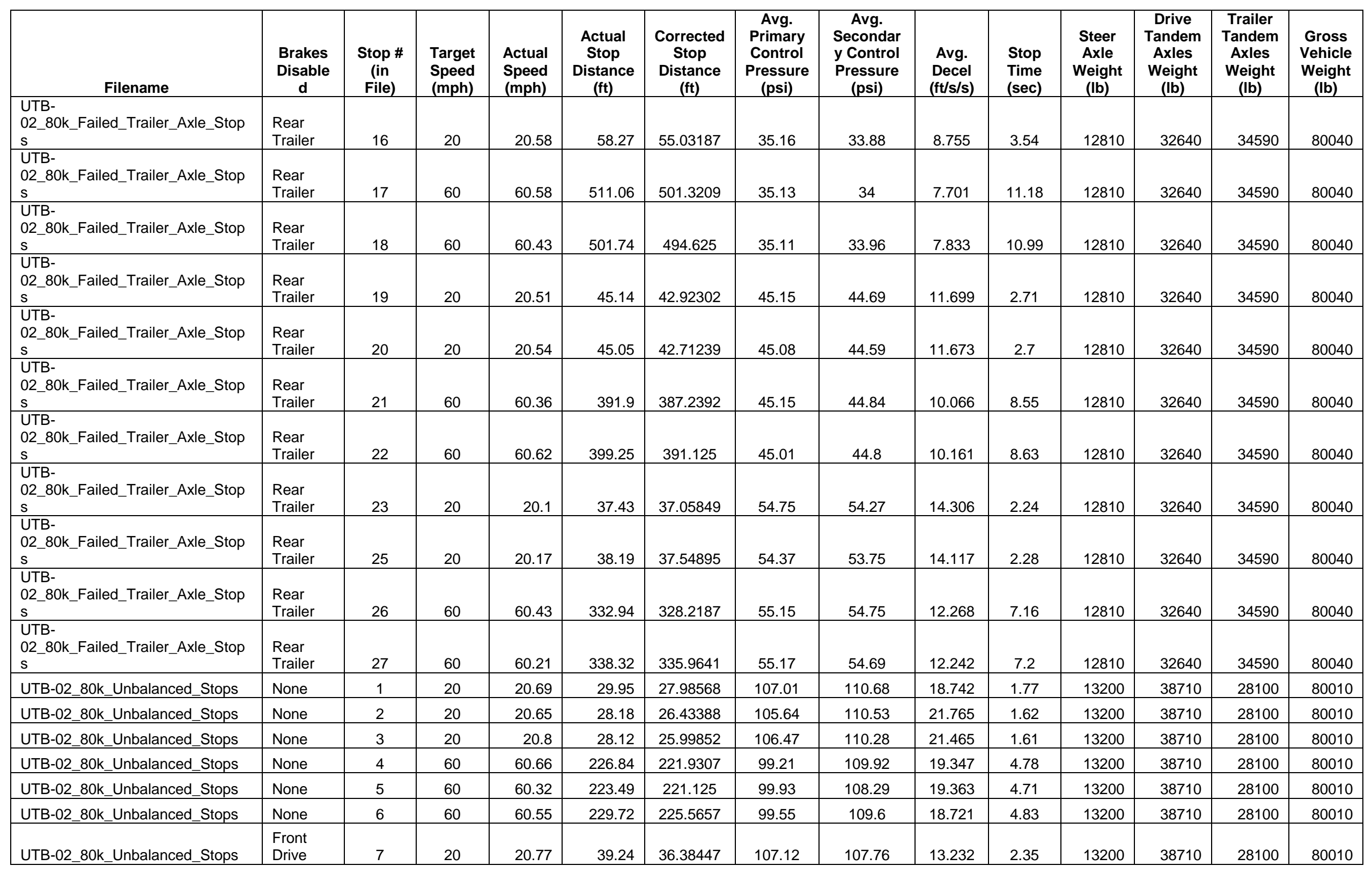




\begin{tabular}{|c|c|c|c|c|c|c|c|c|c|c|c|c|c|c|}
\hline Filename & $\begin{array}{c}\text { Brakes } \\
\text { Disable } \\
\text { d }\end{array}$ & $\begin{array}{l}\text { Stop \# } \\
\text { (in } \\
\text { File) }\end{array}$ & $\begin{array}{l}\text { Target } \\
\text { Speed } \\
(\mathrm{mph})\end{array}$ & $\begin{array}{l}\text { Actual } \\
\text { Speed } \\
\text { (mph) }\end{array}$ & $\begin{array}{c}\text { Actual } \\
\text { Stop } \\
\text { Distance } \\
\text { (ft) }\end{array}$ & $\begin{array}{c}\text { Corrected } \\
\text { Stop } \\
\text { Distance } \\
\text { (ft) }\end{array}$ & $\begin{array}{c}\text { Avg. } \\
\text { Primary } \\
\text { Control } \\
\text { Pressure } \\
\text { (psi) } \\
\end{array}$ & $\begin{array}{c}\text { Avg. } \\
\text { Secondar } \\
\text { y Control } \\
\text { Pressure } \\
\text { (psi) }\end{array}$ & $\begin{array}{l}\text { Avg. } \\
\text { Decel } \\
\text { (ft/s/s) }\end{array}$ & $\begin{array}{l}\text { Stop } \\
\text { Time } \\
\text { (sec) }\end{array}$ & $\begin{array}{c}\text { Steer } \\
\text { Axle } \\
\text { Weight } \\
\text { (lb) }\end{array}$ & $\begin{array}{c}\text { Drive } \\
\text { Tandem } \\
\text { Axles } \\
\text { Weight } \\
\text { (Ib) } \\
\end{array}$ & $\begin{array}{c}\text { Trailer } \\
\text { Tandem } \\
\text { Axles } \\
\text { Weight } \\
\text { (Ib) } \\
\end{array}$ & $\begin{array}{c}\text { Gross } \\
\text { Vehicle } \\
\text { Weight } \\
\text { (lb) } \\
\end{array}$ \\
\hline UTB-02_80k_Unbalanced_Stops & $\begin{array}{l}\text { Front } \\
\text { Drive } \\
\end{array}$ & 8 & 20 & 20.54 & 39.04 & 37.01425 & 108.88 & 109.36 & 13.306 & 2.34 & 13200 & 38710 & 28100 & 80010 \\
\hline UTB-02_80k_Unbalanced_Stops & $\begin{array}{l}\text { Front } \\
\text { Drive } \\
\end{array}$ & 9 & 20 & 20.65 & 39.07 & 36.6491 & 104.93 & 105.51 & 13.395 & 2.37 & 13200 & 38710 & 28100 & 80010 \\
\hline UTB-02_80k_Unbalanced_Stops & $\begin{array}{l}\text { Front } \\
\text { Drive }\end{array}$ & 10 & 60 & 60.55 & 325.23 & 319.3484 & 99.93 & 105.18 & 12.458 & 7.04 & 13200 & 38710 & 28100 & 80010 \\
\hline UTB-02_80k_Unbalanced_Stops & $\begin{array}{l}\text { Front } \\
\text { Drive } \\
\end{array}$ & 11 & 60 & 60.55 & 329.17 & 323.2172 & 99.25 & 103.96 & 12.421 & 7.11 & 13200 & 38710 & 28100 & 80010 \\
\hline UTB-02_80k_Unbalanced_Stops & $\begin{array}{l}\text { Front } \\
\text { Drive } \\
\end{array}$ & 12 & 60 & 60.58 & 324.38 & 318.1984 & 97.41 & 102.67 & 12.51 & 7.06 & 13200 & 38710 & 28100 & 80010 \\
\hline UTB-02_80k_Unbalanced_Stops & $\begin{array}{l}\text { Rear } \\
\text { Trailer }\end{array}$ & 14 & 20 & 20.62 & 29.95 & 28.17601 & 104.3 & 109.37 & 18.931 & 1.75 & 13200 & 38710 & 28100 & 80010 \\
\hline UTB-02_80k_Unbalanced_Stops & $\begin{array}{l}\text { Rear } \\
\text { Trailer }\end{array}$ & 15 & 20 & 20.73 & 31.14 & 28.98545 & 106.89 & 110.53 & 17.92 & 1.82 & 13200 & 38710 & 28100 & 80010 \\
\hline UTB-02_80k_Unbalanced_Stops & $\begin{array}{l}\text { Rear } \\
\text { Trailer }\end{array}$ & 17 & 60 & 60.47 & 247.05 & 243.2246 & 98.71 & 109.92 & 17.093 & 5.26 & 13200 & 38710 & 28100 & 80010 \\
\hline UTB-02_80k_Unbalanced_Stops & $\begin{array}{l}\text { Rear } \\
\text { Trailer }\end{array}$ & 18 & 60 & 60.47 & 254.23 & 250.2934 & 98.7 & 109.79 & 16.661 & 5.41 & 13200 & 38710 & 28100 & 80010 \\
\hline UTB-02_80k_Unbalanced_Stops & $\begin{array}{l}\text { Rear } \\
\text { Trailer }\end{array}$ & 19 & 60 & 60.73 & 251.8 & 245.7829 & 98.8 & 110.43 & 17.035 & 5.33 & 13200 & 38710 & 28100 & 80010 \\
\hline UTB-02_91.2k_Stops & None & 1 & 20 & 20.51 & 28.77 & 27.357 & 108.21 & 110.71 & 18.815 & 1.7 & 13140 & 38240 & 40060 & 91440 \\
\hline UTB-02_91.2k_Stops & None & 2 & 20 & 20.73 & 30.05 & 27.97086 & 106.47 & 108.86 & 19.021 & 1.73 & 13140 & 38240 & 40060 & 91440 \\
\hline UTB-02_91.2k_Stops & None & 3 & 20 & 20.77 & 29.49 & 27.34398 & 106.29 & 110.52 & 19.758 & 1.7 & 13140 & 38240 & 40060 & 91440 \\
\hline UTB-02_91.2k_Stops & None & 4 & 60 & 60.66 & 234.88 & 229.7967 & 99.22 & 108.79 & 18.526 & 4.94 & 13140 & 38240 & 40060 & 91440 \\
\hline UTB-02_91.2k_Stops & None & 5 & 60 & 60.55 & 224.31 & 220.2535 & 100.26 & 110.36 & 19.258 & 4.73 & 13140 & 38240 & 40060 & 91440 \\
\hline UTB-02_91.2k_Stops & None & 6 & 60 & 60.14 & 228.38 & 227.3179 & 99.53 & 109.74 & 19.247 & 4.75 & 13140 & 38240 & 40060 & 91440 \\
\hline UTB-02_91.2k_Stops & $\begin{array}{l}\text { Front } \\
\text { Drive }\end{array}$ & 7 & 20 & 20.69 & 38.94 & 36.38605 & 108.86 & 108.77 & 13.216 & 2.34 & 13140 & 38240 & 40060 & 91440 \\
\hline UTB-02_91.2k_Stops & $\begin{array}{l}\text { Front } \\
\text { Drive }\end{array}$ & 8 & 20 & 20.62 & 39.5 & 37.16035 & 105.92 & 106.53 & 13.385 & 2.33 & 13140 & 38240 & 40060 & 91440 \\
\hline UTB-02_91.2k_Stops & $\begin{array}{l}\text { Front } \\
\text { Drive }\end{array}$ & 10 & 60 & 60.66 & 318.57 & 311.6754 & 100.66 & 105.71 & 13.311 & 6.73 & 13140 & 38240 & 40060 & 91440 \\
\hline UTB-02_91.2k_Stops & $\begin{array}{l}\text { Front } \\
\text { Drive }\end{array}$ & 11 & 60 & 60.58 & 316.31 & 310.2822 & 99.59 & 103.49 & 13.174 & 6.74 & 13140 & 38240 & 40060 & 91440 \\
\hline
\end{tabular}




\begin{tabular}{|c|c|c|c|c|c|c|c|c|c|c|c|c|c|c|}
\hline Filename & $\begin{array}{c}\text { Brakes } \\
\text { Disable } \\
\text { d }\end{array}$ & $\begin{array}{l}\text { Stop \# } \\
\text { (in } \\
\text { File) }\end{array}$ & $\begin{array}{l}\text { Target } \\
\text { Speed } \\
(\mathrm{mph})\end{array}$ & $\begin{array}{l}\text { Actual } \\
\text { Speed } \\
\text { (mph) }\end{array}$ & $\begin{array}{c}\text { Actual } \\
\text { Stop } \\
\text { Distance } \\
\text { (ft) }\end{array}$ & $\begin{array}{c}\text { Corrected } \\
\text { Stop } \\
\text { Distance } \\
\text { (ft) }\end{array}$ & $\begin{array}{c}\text { Avg. } \\
\text { Primary } \\
\text { Control } \\
\text { Pressure } \\
\text { (psi) }\end{array}$ & $\begin{array}{c}\text { Avg. } \\
\text { Secondar } \\
\text { y Control } \\
\text { Pressure } \\
\text { (psi) }\end{array}$ & $\begin{array}{l}\text { Avg. } \\
\text { Decel } \\
\text { (ft/s/s) }\end{array}$ & $\begin{array}{l}\text { Stop } \\
\text { Time } \\
\text { (sec) }\end{array}$ & $\begin{array}{c}\text { Steer } \\
\text { Axle } \\
\text { Weight } \\
\text { (Ib) }\end{array}$ & $\begin{array}{c}\text { Drive } \\
\text { Tandem } \\
\text { Axles } \\
\text { Weight } \\
\text { (Ib) }\end{array}$ & $\begin{array}{c}\text { Trailer } \\
\text { Tandem } \\
\text { Axles } \\
\text { Weight } \\
\text { (Ib) }\end{array}$ & $\begin{array}{c}\text { Gross } \\
\text { Vehicle } \\
\text { Weight } \\
\text { (lb) }\end{array}$ \\
\hline UTB-02_91.2k_Stops & $\begin{array}{l}\text { Rear } \\
\text { Trailer }\end{array}$ & 13 & 20 & 20.43 & 32.61 & 31.25173 & 108.95 & 111.74 & 16.377 & 1.93 & 13140 & 38240 & 40060 & 91440 \\
\hline UTB-02_91.2k_Stops & $\begin{array}{l}\text { Rear } \\
\text { Trailer }\end{array}$ & 14 & 20 & 20.73 & 33.96 & 31.61033 & 105.77 & 109.54 & 15.908 & 2.01 & 13140 & 38240 & 40060 & 91440 \\
\hline UTB-02_91.2k_Stops & $\begin{array}{l}\text { Rear } \\
\text { Trailer }\end{array}$ & 15 & 20 & 20.73 & 34.19 & 31.82442 & 105.27 & 108.75 & 16.919 & 1.98 & 13140 & 38240 & 40060 & 91440 \\
\hline UTB-02_91.2k_Stops & $\begin{array}{l}\text { Rear } \\
\text { Trailer }\end{array}$ & 16 & 60 & 60.51 & 274.61 & 270.0005 & 98.49 & 109.67 & 15.581 & 5.77 & 13140 & 38240 & 40060 & 91440 \\
\hline UTB-02_91.2k_Stops & $\begin{array}{l}\text { Rear } \\
\text { Trailer }\end{array}$ & 17 & 60 & 60.88 & 279.3 & 271.284 & 98.14 & 108.74 & 15.634 & 5.77 & 13140 & 38240 & 40060 & 91440 \\
\hline UTB-02_91.2k_Stops & $\begin{array}{l}\text { Rear } \\
\text { Trailer } \\
\end{array}$ & 19 & 60 & 60.62 & 282.71 & 276.9567 & 94.46 & 108.59 & 15.56 & 5.85 & 13140 & 38240 & 40060 & 91440 \\
\hline UTB-02_97k_Stops & None & 1 & 20 & 20.62 & 31.66 & 29.78472 & 107.02 & 110.03 & 16.403 & 1.87 & 12660 & 33390 & 51070 & 97120 \\
\hline UTB-02_97k_Stops & None & 2 & 20 & 20.54 & 29.95 & 28.39592 & 104.86 & 108.5 & 20.891 & 1.69 & 12660 & 33390 & 51070 & 97120 \\
\hline UTB-02_97k_Stops & None & 4 & 60 & 60.73 & 246.42 & 240.5315 & 98.99 & 106.7 & 17.646 & 5.12 & 12660 & 33390 & 51070 & 97120 \\
\hline UTB-02_97k_Stops & None & 5 & 60 & 60.51 & 236.19 & 232.2254 & 98.21 & 106.97 & 18.236 & 4.98 & 12660 & 33390 & 51070 & 97120 \\
\hline UTB-02_97k_Stops & None & 6 & 60 & 60.7 & 249.34 & 243.6223 & 98.7 & 106.89 & 17.514 & 5.19 & 12660 & 33390 & 51070 & 97120 \\
\hline UTB-02_97k_Stops & $\begin{array}{l}\text { Front } \\
\text { Drive }\end{array}$ & 7 & 20 & 20.65 & 39.27 & 36.83671 & 108.27 & 100.2 & 13.964 & 2.32 & 12660 & 33390 & 51070 & 97120 \\
\hline UTB-02_97k_Stops & $\begin{array}{l}\text { Front } \\
\text { Drive }\end{array}$ & 8 & 20 & 20.69 & 39.96 & 37.33916 & 107.4 & 106.47 & 13.759 & 2.32 & 12660 & 33390 & 51070 & 97120 \\
\hline UTB-02_97k_Stops & $\begin{array}{l}\text { Front } \\
\text { Drive } \\
\end{array}$ & 9 & 20 & 20.77 & 39.93 & 37.02425 & 106.9 & 101.36 & 13.353 & 2.38 & 12660 & 33390 & 51070 & 97120 \\
\hline UTB-02_97k_Stops & $\begin{array}{l}\text { Front } \\
\text { Drive }\end{array}$ & 10 & 60 & 60.66 & 336.45 & 329.1685 & 99.02 & 103.45 & 12.489 & 7.17 & 12660 & 33390 & 51070 & 97120 \\
\hline UTB-02_97k_Stops & $\begin{array}{l}\text { Front } \\
\text { Drive }\end{array}$ & 11 & 60 & 60.62 & 340.42 & 333.4922 & 98.39 & 103.05 & 11.852 & 7.36 & 12660 & 33390 & 51070 & 97120 \\
\hline UTB-02_97k_Stops & $\begin{array}{l}\text { Front } \\
\text { Drive }\end{array}$ & 12 & 60 & 60.7 & 331.89 & 324.2793 & 99.23 & 101.18 & 12.579 & 7.17 & 12660 & 33390 & 51070 & 97120 \\
\hline UTB-02 106k Stops & None & 1 & 20 & 20.54 & 29.59 & 28.0546 & 107.33 & 113.1 & 18.541 & 1.74 & 13710 & 45080 & 47550 & 106340 \\
\hline UTB-02 106k Stops & None & 2 & 20 & 20.77 & 30.02 & 27.83541 & 105.93 & 111.65 & 18.757 & 1.74 & 13710 & 45080 & 47550 & 106340 \\
\hline UTB-02 106k Stops & None & 5 & 60 & 60.17 & 241.01 & 239.6501 & 98.72 & 109.18 & 17.488 & 5.1 & 13710 & 45080 & 47550 & 106340 \\
\hline UTB-02 106k Stops & None & 6 & 60 & 60.14 & 238.71 & 237.5999 & 104.69 & 110.88 & 18.231 & 5.02 & 13710 & 45080 & 47550 & 106340 \\
\hline
\end{tabular}




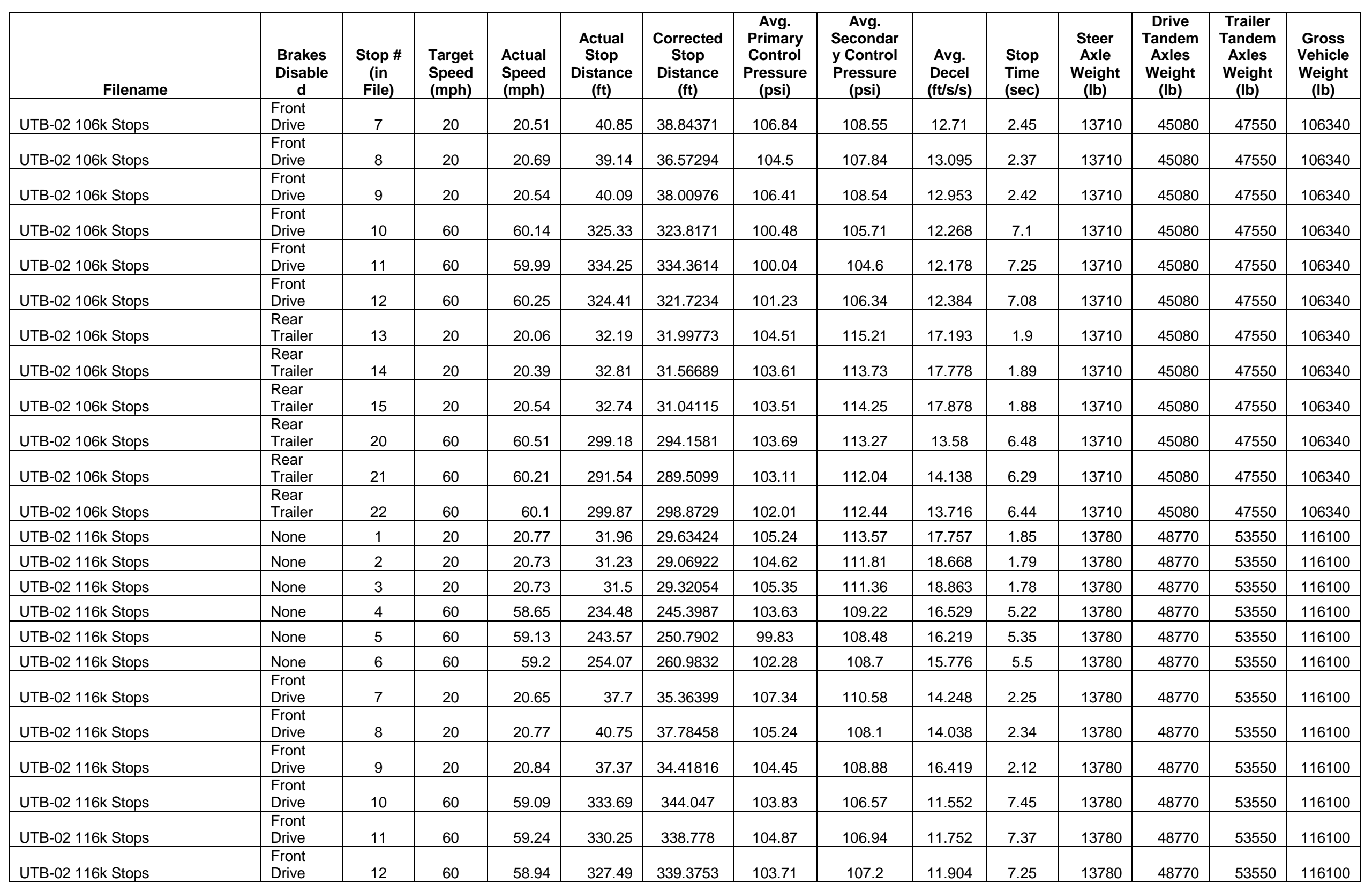




\begin{tabular}{|c|c|c|c|c|c|c|c|c|c|c|c|c|c|c|}
\hline Filename & $\begin{array}{c}\text { Brakes } \\
\text { Disable } \\
\text { d }\end{array}$ & $\begin{array}{l}\text { Stop \# } \\
\text { (in } \\
\text { File) }\end{array}$ & $\begin{array}{l}\text { Target } \\
\text { Speed } \\
(\mathrm{mph})\end{array}$ & $\begin{array}{l}\text { Actual } \\
\text { Speed } \\
\text { (mph) }\end{array}$ & $\begin{array}{c}\text { Actual } \\
\text { Stop } \\
\text { Distance } \\
\text { (ft) }\end{array}$ & $\begin{array}{c}\text { Corrected } \\
\text { Stop } \\
\text { Distance } \\
\text { (ft) }\end{array}$ & $\begin{array}{c}\text { Avg. } \\
\text { Primary } \\
\text { Control } \\
\text { Pressure } \\
\text { (psi) } \\
\end{array}$ & $\begin{array}{c}\text { Avg. } \\
\text { Secondar } \\
\text { y Control } \\
\text { Pressure } \\
\text { (psi) }\end{array}$ & $\begin{array}{l}\text { Avg. } \\
\text { Decel } \\
\text { (ft/s/s) }\end{array}$ & $\begin{array}{l}\text { Stop } \\
\text { Time } \\
\text { (sec) }\end{array}$ & $\begin{array}{c}\text { Steer } \\
\text { Axle } \\
\text { Weight } \\
\text { (lb) }\end{array}$ & $\begin{array}{c}\text { Drive } \\
\text { Tandem } \\
\text { Axles } \\
\text { Weight } \\
\text { (Ib) } \\
\end{array}$ & $\begin{array}{c}\text { Trailer } \\
\text { Tandem } \\
\text { Axles } \\
\text { Weight } \\
\text { (Ib) } \\
\end{array}$ & $\begin{array}{c}\text { Gross } \\
\text { Vehicle } \\
\text { Weight } \\
\text { (lb) } \\
\end{array}$ \\
\hline UTB-02 116k Stops & $\begin{array}{l}\text { Rear } \\
\text { Trailer }\end{array}$ & 14 & 20 & 20.73 & 34.68 & 32.28052 & 104.36 & 113.02 & 17.014 & 1.99 & 13780 & 48770 & 53550 & 116100 \\
\hline UTB-02 116k Stops & $\begin{array}{l}\text { Rear } \\
\text { Trailer }\end{array}$ & 15 & 20 & 20.47 & 34.19 & 32.63799 & 104.58 & 114.37 & 16.255 & 2.01 & 13780 & 48770 & 53550 & 116100 \\
\hline UTB-02 116k Stops & $\begin{array}{l}\text { Rear } \\
\text { Trailer }\end{array}$ & 16 & 60 & 59.24 & 313.25 & 321.339 & 102.14 & 110.8 & 12.389 & 6.95 & 13780 & 48770 & 53550 & 116100 \\
\hline UTB-02 116k Stops & $\begin{array}{l}\text { Rear } \\
\text { Trailer }\end{array}$ & 17 & 60 & 58.94 & 308.83 & 320.0381 & 101.8 & 109.14 & 12.468 & 6.92 & 13780 & 48770 & 53550 & 116100 \\
\hline UTB-02 116k Stops & $\begin{array}{l}\text { Rear } \\
\text { Trailer }\end{array}$ & 18 & 60 & 59.17 & 308.4 & 317.1128 & 102.95 & 109.94 & 12.684 & 6.86 & 13780 & 48770 & 53550 & 116100 \\
\hline
\end{tabular}




\section{APPENDIX B: BRAKE STROKE MEASUREMENT LOG}

\begin{tabular}{|c|c|c|c|c|c|c|c|c|c|c|c|c|c|c|c|c|c|c|c|c|}
\hline AXLE POSITION & 1L & & $1 R$ & & $2 \mathrm{~L}$ & & $2 R$ & & $3 \mathrm{~L}$ & & $3 R$ & & $4 \mathrm{~L}$ & & 4R & & $5 \mathrm{~L}$ & & $5 R$ & \\
\hline BSAP & $21 / 4$ & & $21 / 4$ & & $\begin{array}{r}2 \\
1 / 4 \\
\end{array}$ & & $21 / 4$ & & $21 / 4$ & & $21 / 4$ & & & & & & & & & \\
\hline FREE STROKE & $27 / 8$ & $5 / 8$ & $27 / 8$ & $5 / 8$ & $\begin{array}{r}2 \\
7 / 8 \\
\end{array}$ & $5 / 8$ & $27 / 8$ & $5 / 8$ & $27 / 8$ & $5 / 8$ & $27 / 8$ & $5 / 8$ & & 0 & & 0 & & 0 & & 0 \\
\hline 90 PSI & $37 / 8$ & $\begin{array}{r}1 \\
5 / 8\end{array}$ & $37 / 8$ & $\begin{array}{r}1 \\
5 / 8 \\
\end{array}$ & 4 & $13 / 4$ & 4 & $\begin{array}{ll}13 / 4 \\
\end{array}$ & 4 & $13 / 4$ & 4 & $13 / 4$ & & 0 & & 0 & & 0 & & 0 \\
\hline SPRING BRAKES & & & & & $\begin{array}{r}3 \\
5 / 8 \\
\end{array}$ & $3 / 4$ & $35 / 8$ & $3 / 4$ & & & & & & 0 & & 0 & & 0 & & 0 \\
\hline
\end{tabular}

COMMENTS: $\quad$ Pre Burnish Trailer not measured (free stokes set to 5/8")

DATE:

AXLE POSITION

BSAP

FREE STROKE

90 PSI

SPRING BRAKES

\begin{tabular}{|c|c|c|c|c|}
\hline 1L & & 1R & & 2 \\
\hline $21 / 4$ & & $21 / 4$ & & $1 /$ \\
\hline $\begin{array}{r}2 \\
13 / 16 \\
\end{array}$ & $9 / 16$ & $\begin{array}{r}2 \\
13 / 16 \\
\end{array}$ & $9 / 16$ & $3 /$ \\
\hline $\begin{array}{ll}3 & 3 / 4\end{array}$ & $\begin{array}{r}1 \\
1 / 2 \\
\end{array}$ & $35 / 8$ & $\begin{array}{r}1 \\
3 / 8 \\
\end{array}$ & 7/ \\
\hline & & & & 1 \\
\hline
\end{tabular}

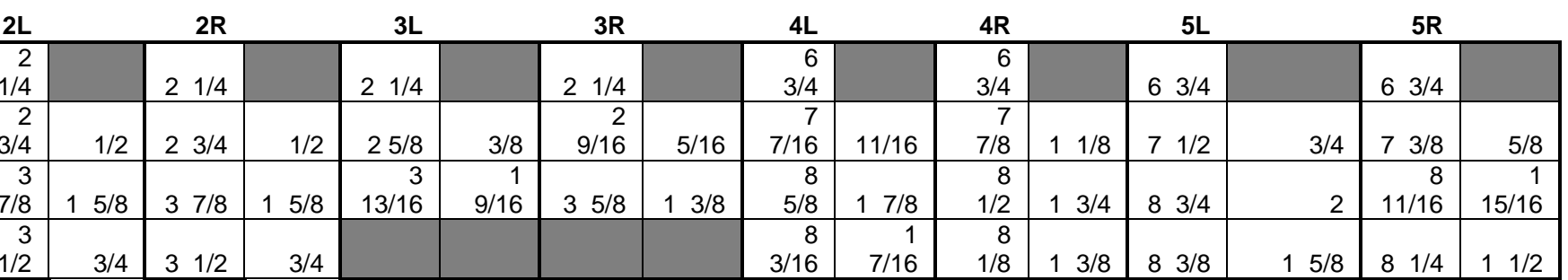

COMMENTS:

Post Burnish

DATE:

$5 / 1 / 2012$

AXLE POSITION

BSAP

FREE STROKE

90 PSI

SPRING BRAKES

\begin{tabular}{|c|c|c|c|c|c|c|c|}
\hline 1L & & $1 R$ & & $2 \mathrm{~L}$ & & $2 R$ & \\
\hline $21 / 4$ & & $21 / 4$ & & $\begin{array}{r}2 \\
1 / 4\end{array}$ & & $21 / 4$ & \\
\hline $\begin{array}{r}2 \\
13 / 16\end{array}$ & $9 / 16$ & $\begin{array}{r}2 \\
13 / 16\end{array}$ & $9 / 16$ & $\begin{array}{r}2 \\
3 / 4\end{array}$ & $1 / 2$ & $23 / 4$ & $1 / 2$ \\
\hline $33 / 4$ & $\begin{array}{r}1 \\
1 / 2\end{array}$ & $35 / 8$ & $\begin{array}{r}1 \\
3 / 8\end{array}$ & $\begin{array}{r}3 \\
7 / 8\end{array}$ & $15 / 8$ & $37 / 8$ & $15 / 8$ \\
\hline & & & & $\begin{array}{r}3 \\
1 / 2\end{array}$ & $3 / 4$ & $\begin{array}{ll}3 & 1 / 2\end{array}$ & $3 / 4$ \\
\hline
\end{tabular}

\begin{tabular}{|r|r|}
\hline \multicolumn{2}{|c|}{ 3L } \\
\hline $21 / 4$ & \\
\hline $25 / 8$ & $3 / 8$ \\
\hline 3 & 1 \\
$13 / 16$ & $9 / 16$ \\
\hline
\end{tabular}

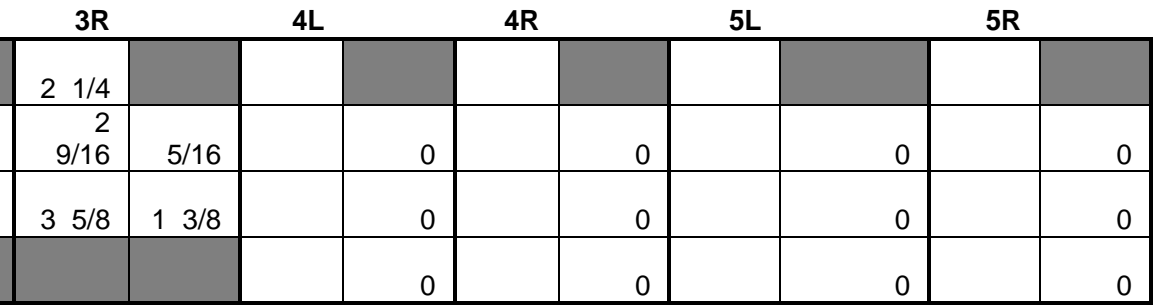
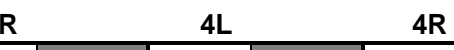

$5 \mathrm{~L}$

$5 \mathbf{R}$

COMMENTS:

Pre Control Trailer

DATE:

$5 / 2 / 2012$ 


\begin{tabular}{|c|c|c|c|c|c|c|c|c|c|c|c|c|c|c|c|c|c|c|c|c|}
\hline AXLE POSITION & $1 \mathrm{~L}$ & & $1 R$ & & $2 \mathrm{~L}$ & & 2R & & $3 \mathrm{~L}$ & & 3R & & 4L & & 4R & & $5 \mathrm{~L}$ & & $5 R$ & \\
\hline BSAP & $21 / 4$ & & $21 / 4$ & & $\begin{array}{r}2 \\
1 / 4 \\
\end{array}$ & & $21 / 4$ & & $21 / 4$ & & $21 / 4$ & & $\begin{array}{r}6 \\
3 / 4 \\
\end{array}$ & & $\begin{array}{r}6 \\
3 / 4 \\
\end{array}$ & & $63 / 4$ & & $\begin{array}{ll}6 & 3 / 4 \\
\end{array}$ & \\
\hline FREE STROKE & $25 / 8$ & $3 / 8$ & $25 / 8$ & $3 / 8$ & $\begin{array}{r}2 \\
1 / 2 \\
\end{array}$ & $1 / 4$ & $\begin{array}{r}2 \\
9 / 16 \\
\end{array}$ & $5 / 16$ & $24 / 9$ & $3 / 16$ & $23 / 8$ & $1 / 8$ & $\begin{array}{r}7 \\
7 / 16 \\
\end{array}$ & $11 / 16$ & $\begin{array}{r}7 \\
3 / 8 \\
\end{array}$ & $5 / 8$ & $75 / 8$ & $7 / 8$ & $\begin{array}{ll}7 & 1 / 2 \\
\end{array}$ & $3 / 4$ \\
\hline 90 PSI & $33 / 8$ & $\begin{array}{r}1 \\
1 / 8 \\
\end{array}$ & $31 / 4$ & 1 & $\begin{array}{r}3 \\
5 / 8 \\
\end{array}$ & $13 / 8$ & $31 / 2$ & $11 / 4$ & $\begin{array}{r}3 \\
7 / 16 \\
\end{array}$ & $\begin{array}{r}1 \\
3 / 16 \\
\end{array}$ & $33 / 8$ & $11 / 8$ & $\begin{array}{r}8 \\
9 / 16 \\
\end{array}$ & $\begin{array}{r}1 \\
13 / 16 \\
\end{array}$ & $\begin{array}{r}8 \\
1 / 2 \\
\end{array}$ & $13 / 4$ & $87 / 8$ & $21 / 8$ & $85 / 8$ & $17 / 8$ \\
\hline PRING BRAKES & & & & & $\begin{array}{r}3 \\
1 / 4 \\
\end{array}$ & $3 / 4$ & $31 / 4$ & $11 / 16$ & & & & & $\begin{array}{r}8 \\
3 / 16 \\
\end{array}$ & $\begin{array}{r}1 \\
7 / 16 \\
\end{array}$ & $\begin{array}{r}8 \\
1 / 8 \\
\end{array}$ & $13 / 8$ & $83 / 8$ & $15 / 8$ & \begin{tabular}{r|}
8 \\
$3 / 16$ \\
\end{tabular} & $\begin{array}{r}1 \\
7 / 16 \\
\end{array}$ \\
\hline
\end{tabular}

COMMENTS: $\quad$ Pre 60k Full Function

DATE:

$5 / 7 / 2012$

AXLE POSITION

BSAP

FREE STROKE

90 PSI

SPRING BRAKES

\begin{tabular}{|c|c|c|c|c|c|c|c|}
\hline 1L & & $1 R$ & & $2 \mathrm{~L}$ & & $2 R$ & \\
\hline $21 / 4$ & & $21 / 4$ & & $\begin{array}{r}2 \\
1 / 4\end{array}$ & & $21 / 4$ & \\
\hline $21 / 2$ & $1 / 4$ & $21 / 2$ & $1 / 4$ & $\begin{array}{r}2 \\
1 / 2\end{array}$ & $1 / 4$ & $21 / 2$ & $1 / 4$ \\
\hline $23 / 8$ & $1 / 8$ & $\begin{array}{ll}3 & 1 / 4\end{array}$ & 1 & $\begin{array}{r}3 \\
1 / 2 \\
\end{array}$ & $11 / 4$ & $31 / 2$ & $11 / 4$ \\
\hline & & & & $\begin{array}{r}3 \\
1 / 4\end{array}$ & $3 / 4$ & $31 / 4$ & $3 / 4$ \\
\hline
\end{tabular}

\begin{tabular}{|c|c|}
\hline \multicolumn{2}{|c|}{$3 \mathrm{~L}$} \\
\hline $21 / 4$ & \\
\hline $23 / 8$ & $1 / 8$ \\
\hline $\begin{array}{ll}3 & 3 / 8\end{array}$ & $11 / 8$ \\
\hline
\end{tabular}

\begin{tabular}{|c|c|}
\hline \multicolumn{2}{|c|}{ 3R } \\
\hline $21 / 4$ & \\
\hline $23 / 8$ & $1 / 8$ \\
\hline $\begin{array}{ll}3 & 3 / 8\end{array}$ & $11 / 8$ \\
\hline
\end{tabular}

\begin{tabular}{|c|c|}
\hline 4L & \\
\hline $\begin{array}{r}6 \\
3 / 4\end{array}$ & \\
\hline 7 & \\
\hline $3 / 8$ & $5 / 8$ \\
\hline 8 & \\
\hline $1 / 2$ & $13 / 4$ \\
\hline 8 & \\
\hline $1 / 8$ & $13 / 8$ \\
\hline
\end{tabular}

\begin{tabular}{|r|r|}
\hline $\mathbf{R}$ & \\
\hline 6 & \\
$3 / 4$ & \\
7 & \\
$3 / 8$ & $5 / 8$ \\
\hline 8 & 1 \\
$7 / 16$ & $11 / 16$ \\
\hline 8 & \\
$1 / 8$ & $13 / 8$ \\
\hline
\end{tabular}

\begin{tabular}{|c|c|c|c|}
\hline $5 \mathrm{~L}$ & & $5 R$ & \\
\hline $\begin{array}{ll}6 & 3 / 4 \\
\end{array}$ & & $63 / 4$ & \\
\hline $\begin{array}{r}7 \\
9 / 16\end{array}$ & $13 / 16$ & $71 / 2$ & $3 / 4$ \\
\hline $85 / 8$ & $17 / 8$ & $\begin{array}{r}88 \\
9 / 16 \\
\end{array}$ & $\begin{array}{r}1 \\
13 / 16 \\
\end{array}$ \\
\hline $\begin{array}{ll}81 / 4 \\
\end{array}$ & $11 / 2$ & $\begin{array}{r}8 \\
3 / 16 \\
\end{array}$ & $\begin{array}{r}1 \\
7 / 16 \\
\end{array}$ \\
\hline
\end{tabular}

COMMENTS:

Pre 60k Failed Drive Axle

DATE:

$5 / 10 / 2012$

AXLE POSITION

BSAP

FREE STROKE

90 PSI

SPRING BRAKES

\begin{tabular}{|c|c|c|c|c|c|c|c|}
\hline 1L & & 1R & & $2 \mathrm{~L}$ & & $2 R$ & \\
\hline $21 / 4$ & & $21 / 4$ & & $\begin{array}{r}2 \\
1 / 4 \\
\end{array}$ & & $21 / 4$ & \\
\hline $21 / 2$ & $1 / 4$ & $21 / 2$ & $1 / 4$ & $\begin{array}{r}2 \\
1 / 2 \\
\end{array}$ & $1 / 4$ & $21 / 2$ & $1 / 4$ \\
\hline $33 / 8$ & $\begin{array}{r}1 \\
1 / 8 \\
\end{array}$ & $\begin{array}{ll}3 & 1 / 4 \\
\end{array}$ & 1 & $\begin{array}{r}3 \\
1 / 2 \\
\end{array}$ & $11 / 4$ & $31 / 2$ & $11 / 4$ \\
\hline & & & & $\begin{array}{r}3 \\
1 / 4 \\
\end{array}$ & $3 / 4$ & $31 / 4$ & $3 / 4$ \\
\hline
\end{tabular}

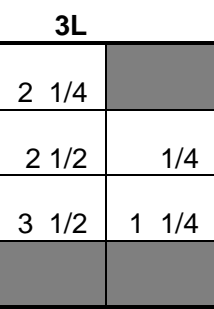

3R

\begin{tabular}{|c|c|c|c|c|c|c|c|c|c|}
\hline & & $4 \mathrm{~L}$ & & $4 R$ & & $J$ & & $\mathbf{R}$ & \\
\hline $21 / 4$ & & $\begin{array}{r}6 \\
3 / 4 \\
\end{array}$ & & $\begin{array}{r}6 \\
3 / 4 \\
\end{array}$ & & $63 / 4$ & & $63 / 4$ & \\
\hline $21 / 4$ & 0 & $\begin{array}{r}7 \\
3 / 8 \\
\end{array}$ & $5 / 8$ & $\begin{array}{r}7 \\
3 / 8 \\
\end{array}$ & $5 / 8$ & $\begin{array}{ll}7 & 1 / 2\end{array}$ & $3 / 4$ & $\begin{array}{lll}7 & 1 / 4\end{array}$ & $1 / 2$ \\
\hline $\begin{array}{ll}3 & 1 / 4\end{array}$ & 1 & $\begin{array}{r}8 \\
1 / 2\end{array}$ & $13 / 4$ & $\begin{array}{r}8 \\
3 / 8\end{array}$ & $15 / 8$ & $81 / 2$ & $13 / 4$ & $81 / 2$ & $13 / 4$ \\
\hline & & $\begin{array}{r}8 \\
1 / 8\end{array}$ & $13 / 8$ & $\begin{array}{r}8 \\
1 / 8\end{array}$ & $13 / 8$ & $81 / 8$ & $13 / 8$ & $81 / 8$ & $13 / 8$ \\
\hline
\end{tabular}

COMMENTS: 


\begin{tabular}{|c|c|c|c|c|c|c|c|c|c|c|c|c|c|c|c|c|c|c|c|c|}
\hline AXLE POSITION & $1 \mathrm{~L}$ & & $1 R$ & & $2 \mathrm{~L}$ & & 2R & & $3 \mathrm{~L}$ & & 3R & & $4 \mathrm{~L}$ & & 4R & & $5 \mathrm{~L}$ & & $5 R$ & \\
\hline BSAP & $21 / 4$ & & $21 / 4$ & & $\begin{array}{r}2 \\
1 / 4 \\
\end{array}$ & & $21 / 4$ & & $21 / 4$ & & $21 / 4$ & & $\begin{array}{r}6 \\
3 / 4 \\
\end{array}$ & & $\begin{array}{r}6 \\
3 / 4 \\
\end{array}$ & & $63 / 4$ & & $\begin{array}{ll}6 & 3 / 4 \\
\end{array}$ & \\
\hline FREE STROKE & $21 / 2$ & $1 / 4$ & $21 / 2$ & $1 / 4$ & $\begin{array}{r}2 \\
1 / 2 \\
\end{array}$ & $1 / 4$ & $21 / 2$ & $1 / 4$ & $21 / 2$ & $1 / 4$ & $25 / 8$ & $3 / 8$ & $\begin{array}{r}7 \\
1 / 2 \\
\end{array}$ & $3 / 4$ & $\begin{array}{r}7 \\
3 / 8 \\
\end{array}$ & $5 / 8$ & $75 / 8$ & $7 / 8$ & $\begin{array}{ll}7 & 1 / 2 \\
\end{array}$ & $3 / 4$ \\
\hline 90 PSI & $33 / 8$ & $\begin{array}{r}1 \\
1 / 8 \\
\end{array}$ & $33 / 8$ & $\begin{array}{r}1 \\
1 / 8 \\
\end{array}$ & $\begin{array}{r}3 \\
1 / 2 \\
\end{array}$ & $11 / 4$ & $\begin{array}{r}3 \\
9 / 16 \\
\end{array}$ & $\begin{array}{r}1 \\
5 / 16 \\
\end{array}$ & $35 / 8$ & $13 / 8$ & $85 / 8$ & $63 / 8$ & $\begin{array}{r}8 \\
5 / 8 \\
\end{array}$ & $17 / 8$ & $\begin{array}{r}8 \\
1 / 2 \\
\end{array}$ & $13 / 4$ & $83 / 4$ & 2 & $83 / 4$ & 2 \\
\hline PRING BRAKES & & & & & $\begin{array}{r}3 \\
1 / 4 \\
\end{array}$ & $3 / 4$ & $31 / 4$ & $3 / 4$ & & & & & $\begin{array}{r}8 \\
1 / 4 \\
\end{array}$ & $11 / 2$ & $\begin{array}{r}8 \\
3 / 16 \\
\end{array}$ & $\begin{array}{r}1 \\
7 / 16 \\
\end{array}$ & $83 / 8$ & $15 / 8$ & $8 \quad 1 / 4$ & $\begin{array}{ll}1 & 1 / 2 \\
\end{array}$ \\
\hline
\end{tabular}

COMMENTS: $\quad$ Pre 80k Full Functioning Brakes

DATE: $\quad 5 / 14 / 2012$

\begin{tabular}{|c|c|c|c|c|c|c|c|c|c|c|c|c|c|c|c|c|c|c|c|c|}
\hline AXLE POSITION & $1 \mathrm{~L}$ & & $1 R$ & & $2 \mathrm{~L}$ & & 2R & & $3 \mathrm{~L}$ & & $3 \mathbf{R}$ & & $4 \mathrm{~L}$ & & 4R & & $5 \mathrm{~L}$ & & $5 R$ & \\
\hline BSAP & $21 / 4$ & & $21 / 4$ & & $\begin{array}{r}2 \\
1 / 4 \\
\end{array}$ & & $21 / 4$ & & $21 / 4$ & & $21 / 4$ & & $\begin{array}{r}6 \\
3 / 4 \\
\end{array}$ & & $\begin{array}{r}6 \\
3 / 4 \\
\end{array}$ & & $\begin{array}{ll}6 & 3 / 4 \\
\end{array}$ & & $\begin{array}{ll}63 / 4 \\
\end{array}$ & \\
\hline FREE STROKE & $21 / 2$ & $1 / 4$ & $21 / 2$ & $1 / 4$ & $\begin{array}{r}2 \\
1 / 2\end{array}$ & $1 / 4$ & $21 / 2$ & $1 / 4$ & $25 / 8$ & $3 / 8$ & $21 / 2$ & $1 / 4$ & $\begin{array}{r}7 \\
1 / 2\end{array}$ & $3 / 4$ & $\begin{array}{r}7 \\
7 / 16\end{array}$ & $11 / 16$ & $\begin{array}{ll}7 & 1 / 2\end{array}$ & $3 / 4$ & $7 \quad 1 / 2$ & $3 / 4$ \\
\hline 90 PSI & $\begin{array}{r}3 \\
5 / 16 \\
\end{array}$ & $\begin{array}{r}1 \\
1 / 16\end{array}$ & $\begin{array}{r}3 \\
5 / 16\end{array}$ & $\begin{array}{r}1 \\
1 / 16\end{array}$ & $\begin{array}{r}3 \\
1 / 2 \\
\end{array}$ & $\begin{array}{ll}1 & 1 / 4 \\
\end{array}$ & $\begin{array}{r}3 \\
9 / 16 \\
\end{array}$ & $\begin{array}{r}1 \\
5 / 16 \\
\end{array}$ & $\begin{array}{r}3 \\
9 / 16\end{array}$ & $\begin{array}{r}1 \\
5 / 16 \\
\end{array}$ & $31 / 2$ & $11 / 4$ & $\begin{array}{r}8 \\
3 / 4 \\
\end{array}$ & 2 & $\begin{array}{r}8 \\
5 / 8 \\
\end{array}$ & $17 / 8$ & $\begin{array}{r}8 \\
13 / 16 \\
\end{array}$ & $21 / 16$ & $\begin{array}{r}8 \\
11 / 16 \\
\end{array}$ & $\begin{array}{r}1 \\
15 / 16 \\
\end{array}$ \\
\hline SPRING BRAKES & & & & & $\begin{array}{r}3 \\
1 / 4\end{array}$ & $3 / 4$ & $31 / 4$ & $3 / 4$ & & & & & $\begin{array}{r}8 \\
1 / 4 \\
\end{array}$ & $11 / 2$ & $\begin{array}{r}8 \\
1 / 4 \\
\end{array}$ & $11 / 2$ & $83 / 8$ & $15 / 8$ & $81 / 4$ & $11 / 2$ \\
\hline
\end{tabular}

COMMENTS:

Pre 80k Failed Drive Axle

DATE:

$5 / 15 / 2012$

AXLE POSITION

BSAP

FREE STROKE

90 PSI

SPRING BRAKES

\begin{tabular}{|c|c|c|c|c|c|c|c|}
\hline 1L & & $1 R$ & & $2 \mathrm{~L}$ & & $2 R$ & \\
\hline $21 / 4$ & & $21 / 4$ & & $\begin{array}{r}2 \\
1 / 4\end{array}$ & & $21 / 4$ & \\
\hline $21 / 2$ & $1 / 4$ & $21 / 2$ & $1 / 4$ & $\begin{array}{r}2 \\
1 / 2 \\
\end{array}$ & $1 / 4$ & $\begin{array}{r}2 \\
9 / 16\end{array}$ & $5 / 16$ \\
\hline $31 / 4$ & 1 & $\begin{array}{r}3 \\
5 / 16 \\
\end{array}$ & $\begin{array}{r}1 \\
1 / 16 \\
\end{array}$ & $\begin{array}{r}3 \\
1 / 2 \\
\end{array}$ & $\begin{array}{ll}1 & 1 / 4 \\
\end{array}$ & $31 / 2$ & $11 / 4$ \\
\hline & & & & $\begin{array}{r}3 \\
1 / 4\end{array}$ & $3 / 4$ & $31 / 4$ & $11 / 16$ \\
\hline
\end{tabular}

\begin{tabular}{|l|l|}
\hline 3L & \\
\hline $21 / 4$ & \\
\hline $23 / 4$ & $1 / 2$ \\
\hline $37 / 8$ & $15 / 8$ \\
\hline
\end{tabular}

3R

\begin{tabular}{|c|c|}
\hline $5 R$ & \\
\hline $63 / 4$ & \\
\hline $73 / 8$ & $5 / 8$ \\
\hline $85 / 8$ & $17 / 8$ \\
\hline $\begin{array}{ll}8 & 1 / 4 \\
\end{array}$ & $11 / 2$ \\
\hline
\end{tabular}

COMMENTS: 


\begin{tabular}{|c|c|c|c|c|c|c|c|c|c|c|c|c|c|c|c|c|c|c|c|c|}
\hline AXLE POSITION & $1 \mathrm{~L}$ & & $1 R$ & & $2 \mathrm{~L}$ & & 2R & & $3 \mathrm{~L}$ & & 3R & & $4 \mathrm{~L}$ & & 4R & & $5 \mathrm{~L}$ & & $5 R$ & \\
\hline BSAP & $21 / 4$ & & $21 / 4$ & & $\begin{array}{r}2 \\
1 / 4 \\
\end{array}$ & & $21 / 4$ & & $21 / 4$ & & $21 / 4$ & & $\begin{array}{r}6 \\
3 / 4 \\
\end{array}$ & & $\begin{array}{r}6 \\
3 / 4 \\
\end{array}$ & & $63 / 4$ & & $\begin{array}{ll}6 & 3 / 4 \\
\end{array}$ & \\
\hline FREE STROKE & $21 / 2$ & $1 / 4$ & $21 / 2$ & $1 / 4$ & $\begin{array}{r}2 \\
3 / 8 \\
\end{array}$ & $1 / 8$ & $23 / 8$ & $1 / 8$ & $25 / 8$ & $3 / 8$ & $\begin{array}{r}2 \\
7 / 16 \\
\end{array}$ & $3 / 16$ & $\begin{array}{r}7 \\
3 / 4 \\
\end{array}$ & 1 & $\begin{array}{r}7 \\
1 / 2 \\
\end{array}$ & $3 / 4$ & $71 / 2$ & $3 / 4$ & $73 / 8$ & $5 / 8$ \\
\hline 90 PSI & $31 / 4$ & 1 & $31 / 2$ & $\begin{array}{r}1 \\
1 / 4 \\
\end{array}$ & $\begin{array}{r}3 \\
3 / 8 \\
\end{array}$ & $\begin{array}{ll}1 & 1 / 8 \\
\end{array}$ & $35 / 8$ & $13 / 8$ & $33 / 4$ & $11 / 2$ & $\begin{array}{r}3 \\
7 / 16 \\
\end{array}$ & $\begin{array}{r}1 \\
3 / 16 \\
\end{array}$ & $\begin{array}{r}8 \\
5 / 8 \\
\end{array}$ & $17 / 8$ & $\begin{array}{r}8 \\
5 / 8 \\
\end{array}$ & $17 / 8$ & $83 / 4$ & 2 & $85 / 8$ & $17 / 8$ \\
\hline PRING BRAKES & & & & & $\begin{array}{r}3 \\
1 / 8 \\
\end{array}$ & $3 / 4$ & $31 / 8$ & $3 / 4$ & & & & & $\begin{array}{r}8 \\
1 / 4 \\
\end{array}$ & $11 / 2$ & $\begin{array}{r}8 \\
1 / 4 \\
\end{array}$ & $11 / 2$ & $83 / 8$ & $15 / 8$ & $8 \quad 1 / 4$ & $11 / 2$ \\
\hline
\end{tabular}

COMMENTS: $\quad$ Pre 80k Unbalanced Full Function

DATE:

$5 / 16 / 2012$

AXLE POSITION

BSAP

FREE STROKE

90 PSI

SPRING BRAKES

\begin{tabular}{|c|c|c|c|c|c|c|c|c|c|}
\hline 1L & & $1 R$ & & 2L & & $2 R$ & & 3L & \\
\hline $21 / 4$ & & $21 / 4$ & & $\begin{array}{r}2 \\
1 / 4\end{array}$ & & $21 / 4$ & & $21 / 4$ & \\
\hline $21 / 2$ & $1 / 4$ & $21 / 2$ & $1 / 4$ & $\begin{array}{r}2 \\
3 / 8\end{array}$ & $1 / 8$ & $23 / 8$ & $1 / 8$ & $21 / 2$ & $1 / 4$ \\
\hline \multirow[t]{2}{*}{$33 / 4$} & $\begin{array}{r}1 \\
1 / 2\end{array}$ & $\begin{array}{ll}3 & 1 / 2\end{array}$ & $\begin{array}{r}1 \\
1 / 4\end{array}$ & $\begin{array}{r}3 \\
3 / 8 \\
\end{array}$ & $\begin{array}{ll}1 / 8 \\
\end{array}$ & $35 / 8$ & $13 / 8$ & $\begin{array}{ll}3 & 1 / 2\end{array}$ & $\begin{array}{ll}1 & 1 / 4\end{array}$ \\
\hline & & & & $\begin{array}{r}3 \\
1 / 8 \\
\end{array}$ & $3 / 4$ & $31 / 8$ & $3 / 4$ & & \\
\hline
\end{tabular}

\begin{tabular}{|c|c|}
\hline $3 R$ & \\
\hline $21 / 4$ & \\
\hline $23 / 8$ & $1 / 8$ \\
\hline $33 / 8$ & $11 / 8$ \\
\hline & \\
\hline
\end{tabular}

\begin{tabular}{|c|c|c|c|}
\hline 4L & & $4 R$ & \\
\hline $\begin{array}{r}6 \\
3 / 4\end{array}$ & & $\begin{array}{r}6 \\
3 / 4\end{array}$ & \\
\hline 7 & & 7 & \\
\hline $7 / 8$ & $11 / 8$ & $1 / 2$ & $3 / 4$ \\
\hline 8 & & 8 & \\
\hline $1 / 2$ & $13 / 4$ & $1 / 2$ & $13 / 4$ \\
\hline $\begin{array}{r}8 \\
3 / 16\end{array}$ & $\begin{array}{r}1 \\
7 / 16\end{array}$ & $\begin{array}{r}8 \\
3 / 16\end{array}$ & $\begin{array}{r}1 \\
711\end{array}$ \\
\hline
\end{tabular}

\begin{tabular}{|c|c|c|c|}
\hline $5 \mathrm{~L}$ & & $5 R$ & \\
\hline $63 / 4$ & & $\begin{array}{ll}6 & 3 / 4\end{array}$ & \\
\hline $71 / 2$ & $3 / 4$ & $73 / 8$ & $5 / 8$ \\
\hline $85 / 8$ & $17 / 8$ & $\begin{array}{r}8 \\
9 / 16 \\
\end{array}$ & $\begin{array}{r}1 \\
13 / 16 \\
\end{array}$ \\
\hline $81 / 4$ & $11 / 2$ & $\begin{array}{ll}8 & 1 / 4 \\
\end{array}$ & $11 / 2$ \\
\hline
\end{tabular}

COMMENTS:

Pre 80k Unbalanced Failed Drive Axle

DATE:

$5 / 17 / 2012$

AXLE POSITION

BSAP

FREE STROKE

90 PSI

SPRING BRAKES

\begin{tabular}{|c|c|c|c|c|}
\hline 1L & & $1 R$ & & $2 \mathrm{~L}$ \\
\hline $21 / 4$ & & $21 / 4$ & & $\begin{array}{r}2 \\
1 / 4\end{array}$ \\
\hline $21 / 2$ & $1 / 4$ & $21 / 2$ & $1 / 4$ & $\begin{array}{r}2 \\
1 / 2\end{array}$ \\
\hline $\begin{array}{ll}31 / 4 \\
\end{array}$ & 1 & $\begin{array}{ll}3 & 1 / 4\end{array}$ & 1 & $\begin{array}{r}3 \\
5 / 8\end{array}$ \\
\hline & & & & $\begin{array}{r}3 \\
1 / 8\end{array}$ \\
\hline
\end{tabular}

\begin{tabular}{|c|c|c|c|}
\hline $2 R$ & & $3 L$ & \\
\hline $2 \quad 1 / 4$ & & $21 / 4$ & \\
\hline $2 \quad 1 / 2$ & $1 / 4$ & $21 / 2$ & $1 / 4$ \\
\hline $\begin{array}{ll}3 & 1 / 2 \\
\end{array}$ & $11 / 4$ & $35 / 8$ & $13 / 8$ \\
\hline $\begin{array}{ll}3 & 1 / 8 \\
\end{array}$ & $5 / 8$ & & \\
\hline
\end{tabular}

3R

\begin{tabular}{|c|c|c|c|c|c|c|c|c|c|}
\hline & & $4 \mathrm{~L}$ & & $4 R$ & & & & & \\
\hline $21 / 4$ & & $\begin{array}{r}6 \\
3 / 4 \\
\end{array}$ & & $\begin{array}{r}6 \\
3 / 4 \\
\end{array}$ & & $\begin{array}{ll}6 & 3 / 4 \\
\end{array}$ & & $63 / 4$ & \\
\hline $21 / 2$ & $1 / 4$ & $\begin{array}{r}7 \\
1 / 2 \\
\end{array}$ & $3 / 4$ & $\begin{array}{r}7 \\
7 / 16 \\
\end{array}$ & $11 / 16$ & $\begin{array}{ll}7 & 1 / 2 \\
\end{array}$ & $3 / 4$ & $73 / 8$ & $5 / 8$ \\
\hline $35 / 8$ & $13 / 8$ & $\begin{array}{r}8 \\
1 / 2 \\
\end{array}$ & $13 / 4$ & $\begin{array}{r}8 \\
1 / 2 \\
\end{array}$ & $13 / 4$ & $85 / 8$ & $17 / 8$ & $\begin{array}{r}8 \\
7 / 16 \\
\end{array}$ & $\begin{array}{r}1 \\
11 / 16 \\
\end{array}$ \\
\hline & & $\begin{array}{r}8 \\
3 / 16\end{array}$ & $\begin{array}{r}1 \\
7 / 16\end{array}$ & $\begin{array}{r}8 \\
3 / 16\end{array}$ & $\begin{array}{r}1 \\
7 / 16\end{array}$ & $81 / 4$ & $11 / 2$ & $81 / 4$ & $11 / 2$ \\
\hline
\end{tabular}

COMMENTS: 


\begin{tabular}{|c|c|c|c|c|c|c|c|c|c|c|c|c|c|c|c|c|c|c|c|c|}
\hline AXLE POSITION & $1 \mathrm{~L}$ & & $1 R$ & & $2 \mathrm{~L}$ & & $2 \mathbf{R}$ & & $3 \mathrm{~L}$ & & $3 \mathbf{R}$ & & $4 \mathrm{~L}$ & & 4R & & $5 \mathrm{~L}$ & & $5 R$ & \\
\hline BSAP & $21 / 4$ & & $21 / 4$ & & $\begin{array}{r}2 \\
1 / 4 \\
\end{array}$ & & $21 / 4$ & & $21 / 4$ & & $21 / 4$ & & $\begin{array}{r}6 \\
3 / 4 \\
\end{array}$ & & $\begin{array}{r}6 \\
3 / 4 \\
\end{array}$ & & $\begin{array}{lll}6 & 3 / 4 \\
\end{array}$ & & $\begin{array}{lll}6 & 3 / 4 \\
\end{array}$ & \\
\hline FREE STROKE & $21 / 2$ & $1 / 4$ & $21 / 2$ & $1 / 4$ & $\begin{array}{r}2 \\
1 / 2 \\
\end{array}$ & $1 / 4$ & $21 / 2$ & $1 / 4$ & $21 / 2$ & $1 / 4$ & $21 / 2$ & $1 / 4$ & $\begin{array}{r}7 \\
1 / 2 \\
\end{array}$ & $3 / 4$ & \begin{tabular}{r|}
7 \\
$7 / 16$ \\
\end{tabular} & $11 / 16$ & $\begin{array}{ll}7 & 1 / 2 \\
\end{array}$ & $3 / 4$ & $73 / 8$ & $5 / 8$ \\
\hline $90 \mathrm{PSI}$ & $31 / 4$ & 1 & $31 / 4$ & 1 & $\begin{array}{r}3 \\
5 / 8 \\
\end{array}$ & $13 / 8$ & $31 / 2$ & $11 / 4$ & $35 / 8$ & $13 / 8$ & $35 / 8$ & $13 / 8$ & $\begin{array}{r}8 \\
1 / 2 \\
\end{array}$ & $13 / 4$ & $\begin{array}{r}8 \\
1 / 2 \\
\end{array}$ & $13 / 4$ & $85 / 8$ & $17 / 8$ & $\begin{array}{r}8 \\
7 / 16 \\
\end{array}$ & $\begin{array}{r}1 \\
11 / 16 \\
\end{array}$ \\
\hline SPRING BRAKES & & & & & $\begin{array}{r}3 \\
1 / 8 \\
\end{array}$ & $5 / 8$ & $31 / 8$ & $5 / 8$ & & & & & $\begin{array}{r}8 \\
3 / 16 \\
\end{array}$ & $\begin{array}{r}1 \\
7 / 16 \\
\end{array}$ & $\begin{array}{r}8 \\
3 / 16 \\
\end{array}$ & $\begin{array}{r}1 \\
7 / 16 \\
\end{array}$ & $81 / 4$ & $\begin{array}{lll}1 & 1 / 2 \\
\end{array}$ & $81 / 4$ & $11 / 2$ \\
\hline
\end{tabular}

\section{COMMENTS:}

Pre 91.2k Full Function

DATE:

$5 / 18 / 2012$

AXLE POSITION

BSAP

FREE STROKE

90 PSI

SPRING BRAKES

\begin{tabular}{|c|c|c|c|c|c|c|c|}
\hline 1L & & $1 R$ & & $2 \mathrm{~L}$ & & $2 R$ & \\
\hline $21 / 4$ & & $21 / 4$ & & $\begin{array}{r}2 \\
1 / 4\end{array}$ & & $21 / 4$ & \\
\hline $21 / 2$ & $1 / 4$ & $21 / 2$ & $1 / 4$ & $\begin{array}{r}2 \\
1 / 2 \\
\end{array}$ & $1 / 4$ & $21 / 2$ & $1 / 4$ \\
\hline \multirow[t]{2}{*}{$\begin{array}{ll}3 & 1 / 4\end{array}$} & 1 & $\begin{array}{ll}3 & 1 / 4\end{array}$ & 1 & $\begin{array}{r}3 \\
1 / 2 \\
\end{array}$ & $11 / 4$ & $31 / 2$ & $11 / 4$ \\
\hline & & & & $\begin{array}{r}3 \\
1 / 4\end{array}$ & $3 / 4$ & $\begin{array}{r}3 \\
3 / 16\end{array}$ & $11 / 16$ \\
\hline
\end{tabular}

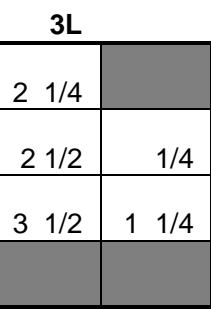

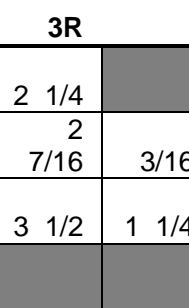

\begin{tabular}{|r|r|r|r|}
\multicolumn{4}{|c}{$\mathbf{4 L}$} \\
\hline 6 & & 6 & \\
$3 / 4$ & & $3 / 4$ & \\
7 & & 7 & \\
$1 / 2$ & $3 / 4$ & $1 / 2$ & $3 / 4$ \\
8 & & 8 & \\
$5 / 8$ & $17 / 8$ & $1 / 2$ & $13 / 4$ \\
8 & 1 & 8 & 1 \\
$3 / 16$ & $7 / 16$ & $3 / 16$ & $7 / 16$ \\
\hline
\end{tabular}

\begin{tabular}{|c|c|c|c|}
\hline $5 \mathrm{~L}$ & \multicolumn{3}{|c|}{$5 R$} \\
\hline $63 / 4$ & & $\begin{array}{lll}6 & 3 / 4 \\
\end{array}$ & \\
\hline $\begin{array}{ll}7 & 1 / 2 \\
\end{array}$ & $3 / 4$ & $73 / 8$ & $5 / 8$ \\
\hline $83 / 4$ & 2 & $85 / 8$ & $17 / 8$ \\
\hline $83 / 8$ & $15 / 8$ & $\begin{array}{ll}8 & 1 / 4 \\
\end{array}$ & $11 / 2$ \\
\hline
\end{tabular}

COMMENTS:

Pre 91.2k Failed Drive Axle

DATE:

$5 / 18 / 2012$

AXLE POSITION

BSAP

FREE STROKE

90 PSI

SPRING BRAKES

\begin{tabular}{|c|c|c|c|c|c|c|c|c|c|}
\hline 1L & & 1R & & $2 \mathrm{~L}$ & & $2 R$ & & $3 \mathrm{~L}$ & \\
\hline $21 / 4$ & & $21 / 4$ & & $\begin{array}{r}2 \\
1 / 4\end{array}$ & & $\begin{array}{lll}2 & 1 / 4\end{array}$ & & $21 / 4$ & \\
\hline $21 / 2$ & $1 / 4$ & $\begin{array}{lll}2 & 1 / 2\end{array}$ & $1 / 4$ & $\begin{array}{r}2 \\
1 / 2\end{array}$ & $1 / 4$ & $21 / 2$ & $1 / 4$ & $21 / 2$ & $1 / 4$ \\
\hline $\begin{array}{ll}3 & 1 / 4\end{array}$ & 1 & $\begin{array}{ll}3 & 1 / 4\end{array}$ & 1 & $\begin{array}{r}3 \\
1 / 4\end{array}$ & 1 & $\begin{array}{ll}3 & 1 / 4\end{array}$ & 1 & $\begin{array}{r}3 \\
5 / 16\end{array}$ & $\begin{array}{r}1 \\
1 / 16\end{array}$ \\
\hline & & & & $\begin{array}{r}3 \\
1 / 4\end{array}$ & $3 / 4$ & $\begin{array}{ll}31 / 8 \\
\end{array}$ & $5 / 8$ & & \\
\hline
\end{tabular}

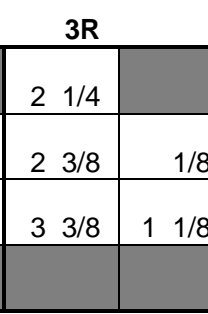

$4 \mathrm{~L}$

\begin{tabular}{|c|c|c|c|c|c|}
\hline 4R & & $5 \mathrm{~L}$ & & $5 R$ & \\
\hline $\begin{array}{r}6 \\
3 / 4\end{array}$ & & $\begin{array}{ll}6 & 3 / 4\end{array}$ & & $63 / 4$ & \\
\hline $\begin{array}{r}7 \\
3 / 8\end{array}$ & $5 / 8$ & $\begin{array}{ll}7 & 3 / 8\end{array}$ & $5 / 8$ & $\begin{array}{r}7 \\
5 / 16\end{array}$ & $9 / 16$ \\
\hline $\begin{array}{r}8 \\
7 / 16\end{array}$ & $\begin{array}{r}1 \\
11 / 16\end{array}$ & $85 / 8$ & $17 / 8$ & $85 / 8$ & $17 / 8$ \\
\hline $\begin{array}{r}8 \\
3 / 16\end{array}$ & $\begin{array}{r}1 \\
7 / 16\end{array}$ & $\begin{array}{ll}8 & 1 / 4\end{array}$ & $11 / 2$ & $81 / 8$ & $13 / 8$ \\
\hline
\end{tabular}

COMMENTS: 


\begin{tabular}{|c|c|c|c|c|c|c|c|c|c|c|c|c|c|c|c|c|c|c|c|c|}
\hline AXLE POSITION & $1 \mathrm{~L}$ & & $1 R$ & & $2 \mathrm{~L}$ & & $2 \mathbf{R}$ & & $3 \mathrm{~L}$ & & $3 \mathbf{R}$ & & $4 \mathrm{~L}$ & & 4R & & $5 \mathrm{~L}$ & & $5 R$ & \\
\hline BSAP & $21 / 4$ & & $21 / 4$ & & $\begin{array}{r}2 \\
1 / 4 \\
\end{array}$ & & $21 / 4$ & & $21 / 4$ & & $21 / 4$ & & $\begin{array}{r}6 \\
3 / 4 \\
\end{array}$ & & $\begin{array}{r}6 \\
3 / 4 \\
\end{array}$ & & $\begin{array}{lll}6 & 3 / 4 \\
\end{array}$ & & $\begin{array}{lll}6 & 3 / 4 \\
\end{array}$ & \\
\hline FREE STROKE & $21 / 2$ & $1 / 4$ & $21 / 2$ & $1 / 4$ & $\begin{array}{r}2 \\
1 / 2 \\
\end{array}$ & $1 / 4$ & $23 / 8$ & $1 / 8$ & $25 / 8$ & $3 / 8$ & $23 / 8$ & $1 / 8$ & $\begin{array}{r}7 \\
3 / 8 \\
\end{array}$ & $5 / 8$ & $\begin{array}{r}7 \\
3 / 8 \\
\end{array}$ & $5 / 8$ & $73 / 8$ & $5 / 8$ & \begin{tabular}{r|}
7 \\
$5 / 16$ \\
\end{tabular} & $9 / 16$ \\
\hline $90 \mathrm{PSI}$ & $31 / 4$ & 1 & $31 / 4$ & 1 & $\begin{array}{r}3 \\
3 / 4 \\
\end{array}$ & $\begin{array}{ll}1 & 1 / 2 \\
\end{array}$ & $\begin{array}{r}3 \\
9 / 16 \\
\end{array}$ & $\begin{array}{r}1 \\
5 / 16 \\
\end{array}$ & $33 / 4$ & $11 / 2$ & $31 / 2$ & $11 / 4$ & $\begin{array}{r}8 \\
5 / 8 \\
\end{array}$ & $17 / 8$ & $\begin{array}{r}8 \\
9 / 16 \\
\end{array}$ & $\begin{array}{r}1 \\
13 / 16 \\
\end{array}$ & $81 / 8$ & $13 / 8$ & $81 / 8$ & $13 / 8$ \\
\hline SPRING BRAKES & & & & & $\begin{array}{r}3 \\
1 / 4 \\
\end{array}$ & $3 / 4$ & $31 / 8$ & $3 / 4$ & & & & & $\begin{array}{r}8 \\
3 / 16 \\
\end{array}$ & $\begin{array}{r}1 \\
7 / 16 \\
\end{array}$ & $\begin{array}{r}8 \\
3 / 16 \\
\end{array}$ & $\begin{array}{r}1 \\
7 / 16 \\
\end{array}$ & $81 / 4$ & $\begin{array}{ll}1 & 1 / 2 \\
\end{array}$ & $\begin{array}{r}8 \\
3 / 16 \\
\end{array}$ & $\begin{array}{r}1 \\
7 / 16 \\
\end{array}$ \\
\hline
\end{tabular}

COMMENTS: Pre 97k Full Function

DATE:

$5 / 19 / 2012$

AXLE POSITION

BSAP

FREE STROKE

90 PSI

SPRING BRAKES

\begin{tabular}{|c|c|c|c|c|c|c|c|}
\hline $1 \mathrm{~L}$ & & $1 R$ & & $2 \mathrm{~L}$ & & $2 R$ & \\
\hline $21 / 4$ & & $21 / 4$ & & $\begin{array}{r}2 \\
1 / 4\end{array}$ & & $21 / 4$ & \\
\hline $21 / 2$ & $1 / 4$ & $21 / 2$ & $1 / 4$ & $\begin{array}{r}2 \\
1 / 2\end{array}$ & $1 / 4$ & $23 / 8$ & $1 / 8$ \\
\hline $\begin{array}{ll}3 & 1 / 4\end{array}$ & 1 & $31 / 4$ & 1 & $\begin{array}{r}3 \\
9 / 16 \\
\end{array}$ & $\begin{array}{r}1 \\
5 / 16\end{array}$ & $31 / 2$ & $\begin{array}{ll}1 & 1 / 4 \\
\end{array}$ \\
\hline & & & & $\begin{array}{r}3 \\
1 / 4\end{array}$ & $3 / 4$ & $31 / 8$ & $3 / 4$ \\
\hline
\end{tabular}

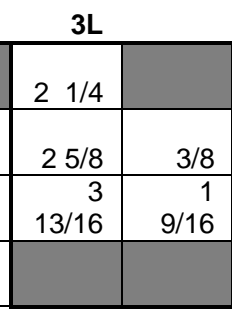

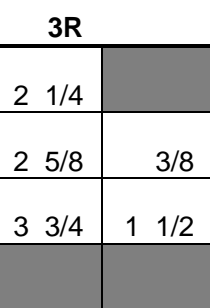

\begin{tabular}{|c|c|c|c|}
\hline $4 \mathrm{~L}$ & & $4 R$ & \\
\hline $\begin{array}{r}6 \\
3 / 4\end{array}$ & & $\begin{array}{r}6 \\
3 / 4\end{array}$ & \\
\hline 7 & & 7 & \\
\hline $3 / 8$ & $5 / 8$ & $3 / 8$ & $5 / 8$ \\
\hline 8 & & 8 & \\
\hline $1 / 2$ & $13 / 4$ & $5 / 8$ & $17 / 8$ \\
\hline 8 & 1 & 8 & 1 \\
\hline $7 / 16$ & $11 / 16$ & $3 / 16$ & $7 / 16$ \\
\hline
\end{tabular}

\begin{tabular}{|c|c|c|c|}
\hline $5 \mathrm{~L}$ & & $5 R$ & \\
\hline $\begin{array}{ll}6 & 3 / 4 \\
\end{array}$ & & $\begin{array}{lll}6 & 3 / 4 \\
\end{array}$ & \\
\hline $\begin{array}{ll}7 & 1 / 2 \\
\end{array}$ & $3 / 4$ & $73 / 8$ & $5 / 8$ \\
\hline $83 / 4$ & 2 & $\begin{array}{r}8 \\
9 / 16 \\
\end{array}$ & $\begin{array}{r}1 \\
13 / 16 \\
\end{array}$ \\
\hline $\begin{array}{ll}8 & 1 / 4 \\
\end{array}$ & $11 / 2$ & $\begin{array}{r}8 \\
3 / 16 \\
\end{array}$ & $\begin{array}{r}1 \\
7 / 16 \\
\end{array}$ \\
\hline
\end{tabular}

COMMENTS:

Pre 97k Failed Drive Axle

DATE:

$5 / 20 / 2012$

AXLE POSITION

BSAP

FREE STROKE

90 PSI

SPRING BRAKES

\begin{tabular}{|c|c|c|c|c|}
\hline 1L & & $1 R$ & & $2 \mathrm{~L}$ \\
\hline $21 / 4$ & & $21 / 4$ & & $\begin{array}{r}2 \\
1 / 4\end{array}$ \\
\hline $21 / 2$ & $1 / 4$ & $21 / 2$ & $1 / 4$ & $\begin{array}{r}2 \\
1 / 2\end{array}$ \\
\hline $\begin{array}{ll}31 / 4 \\
\end{array}$ & 1 & $\begin{array}{ll}3 & 1 / 4\end{array}$ & 1 & $\begin{array}{r}3 \\
1 / 2 \\
\end{array}$ \\
\hline & & & & $\begin{array}{r}3 \\
1 / 4\end{array}$ \\
\hline
\end{tabular}

\begin{tabular}{|c|c|c|c|}
\hline $2 R$ & & $3 \mathrm{~L}$ & \\
\hline $2 \quad 1 / 4$ & & $21 / 4$ & \\
\hline 2 1/2 & $1 / 4$ & $21 / 2$ & $1 / 4$ \\
\hline $\begin{array}{ll}3 & 1 / 2\end{array}$ & $11 / 4$ & $31 / 2$ & $11 / 4$ \\
\hline & & & \\
\hline
\end{tabular}

3R

\begin{tabular}{|c|c|c|c|c|c|c|c|c|c|}
\hline$U_{1}$ & & $4 \mathrm{~L}$ & & $4 R$ & & $J L$ & & $\mathbf{R}$ & \\
\hline $21 / 4$ & & $\begin{array}{r}6 \\
3 / 4 \\
\end{array}$ & & $\begin{array}{r}6 \\
3 / 4 \\
\end{array}$ & & $\begin{array}{ll}6 & 3 / 4\end{array}$ & & $63 / 4$ & \\
\hline $21 / 2$ & $1 / 4$ & $\begin{array}{r}7 \\
3 / 8 \\
\end{array}$ & $5 / 8$ & $\begin{array}{r}7 \\
3 / 8 \\
\end{array}$ & $5 / 8$ & $\begin{array}{ll}7 & 1 / 2 \\
\end{array}$ & $3 / 4$ & $73 / 8$ & $5 / 8$ \\
\hline $\begin{array}{ll}3 & 1 / 2\end{array}$ & $\begin{array}{ll}1 & 1 / 4 \\
\end{array}$ & $\begin{array}{r}8 \\
1 / 2 \\
\end{array}$ & $13 / 4$ & $\begin{array}{r}8 \\
5 / 8 \\
\end{array}$ & $17 / 8$ & $\begin{array}{ll}8 & 3 / 4 \\
\end{array}$ & 2 & $\begin{array}{r}8 \\
9 / 16 \\
\end{array}$ & $\begin{array}{r}1 \\
13 / 16 \\
\end{array}$ \\
\hline & & $\begin{array}{r}8 \\
3 / 16 \\
\end{array}$ & $\begin{array}{r}1 \\
7 / 16\end{array}$ & $\begin{array}{r}8 \\
3 / 16\end{array}$ & $\begin{array}{r}1 \\
7 / 16\end{array}$ & $\begin{array}{ll}8 & 1 / 4\end{array}$ & $\begin{array}{ll}1 & 1 / 2\end{array}$ & $\begin{array}{r}8 \\
3 / 16\end{array}$ & $\begin{array}{r}1 \\
7 / 16\end{array}$ \\
\hline
\end{tabular}

COMMENTS: 


\begin{tabular}{|c|c|c|c|c|c|c|c|c|c|c|c|c|c|c|c|c|c|c|c|c|}
\hline AXLE POSITION & $1 \mathrm{~L}$ & & $1 R$ & & $2 \mathrm{~L}$ & & 2R & & $3 \mathrm{~L}$ & & 3R & & 4L & & 4R & & $5 \mathrm{~L}$ & & $5 R$ & \\
\hline BSAP & $21 / 4$ & & $21 / 4$ & & $\begin{array}{r}2 \\
1 / 4 \\
\end{array}$ & & $21 / 4$ & & $21 / 4$ & & $21 / 4$ & & $\begin{array}{r}6 \\
3 / 4 \\
\end{array}$ & & $\begin{array}{r}6 \\
3 / 4 \\
\end{array}$ & & $63 / 4$ & & $\begin{array}{ll}6 & 3 / 4 \\
\end{array}$ & \\
\hline FREE STROKE & $21 / 2$ & $1 / 4$ & $21 / 2$ & $1 / 4$ & $\begin{array}{r}2 \\
3 / 8 \\
\end{array}$ & $1 / 8$ & $23 / 8$ & $1 / 8$ & $24 / 7$ & $5 / 16$ & $25 / 8$ & $3 / 8$ & $\begin{array}{r}7 \\
1 / 2 \\
\end{array}$ & $3 / 4$ & $\begin{array}{r}7 \\
1 / 2 \\
\end{array}$ & $3 / 4$ & $71 / 2$ & $3 / 4$ & $73 / 8$ & $5 / 8$ \\
\hline 90 PSI & $31 / 4$ & 1 & $31 / 4$ & 1 & $\begin{array}{r}3 \\
3 / 8 \\
\end{array}$ & $11 / 8$ & $\begin{array}{r}3 \\
5 / 16 \\
\end{array}$ & $\begin{array}{r}1 \\
1 / 16 \\
\end{array}$ & $33 / 4$ & $11 / 2$ & $33 / 4$ & $11 / 2$ & $\begin{array}{r}8 \\
1 / 2 \\
\end{array}$ & $13 / 4$ & $\begin{array}{r}8 \\
1 / 2 \\
\end{array}$ & $13 / 4$ & $83 / 4$ & 2 & $81 / 2$ & $13 / 4$ \\
\hline SPRING BRAKES & & & & & $\begin{array}{r}3 \\
1 / 8 \\
\end{array}$ & $3 / 4$ & $31 / 8$ & $3 / 4$ & & & & & $\begin{array}{r}8 \\
3 / 16 \\
\end{array}$ & $\begin{array}{r}1 \\
7 / 16 \\
\end{array}$ & $\begin{array}{r}8 \\
3 / 16 \\
\end{array}$ & $\begin{array}{r}1 \\
7 / 16 \\
\end{array}$ & $83 / 8$ & $15 / 8$ & \begin{tabular}{r|}
8 \\
$3 / 16$ \\
\end{tabular} & $\begin{array}{r}1 \\
7 / 16 \\
\end{array}$ \\
\hline
\end{tabular}

COMMENTS: $\quad$ Pre 106k Failed Drive

DATE:

$5 / 22 / 2012$

AXLE POSITION

BSAP

FREE STROKE

90 PSI

SPRING BRAKES

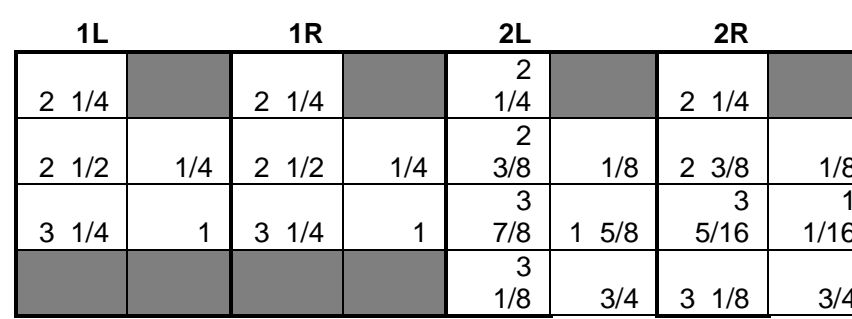

\begin{tabular}{l} 
3L \\
\hline $21 / 4$ \\
\hline $21 / 2$
\end{tabular}

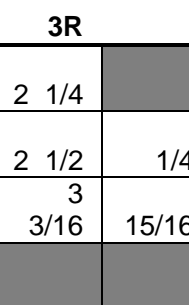

\begin{tabular}{|r|r|r|r|}
\multicolumn{4}{|c}{$\mathbf{4 L}$} \\
\hline 6 & & 6 & \\
$3 / 4$ & & $3 / 4$ & \\
7 & & 7 & \\
$1 / 2$ & $3 / 4$ & $3 / 8$ & $5 / 8$ \\
8 & & 8 & \\
$1 / 2$ & $13 / 4$ & $1 / 2$ & $13 / 4$ \\
8 & 1 & 8 & 1 \\
$3 / 16$ & $7 / 16$ & $3 / 16$ & $7 / 16$ \\
\hline
\end{tabular}

\begin{tabular}{|c|c|c|c|}
\hline $5 \mathrm{~L}$ & \multicolumn{3}{|c|}{$5 R$} \\
\hline $\begin{array}{ll}6 & 3 / 4 \\
\end{array}$ & & $\begin{array}{lll}6 & 3 / 4 \\
\end{array}$ & \\
\hline $\begin{array}{ll}7 & 1 / 2\end{array}$ & $3 / 4$ & $73 / 8$ & $5 / 8$ \\
\hline $\begin{array}{lll}8 & 3 / 4 \\
\end{array}$ & 2 & $81 / 2$ & $13 / 4$ \\
\hline $\begin{array}{lll}8 & 3 / 8\end{array}$ & $15 / 8$ & $\begin{array}{r}8 \\
3 / 16\end{array}$ & $\begin{array}{r}1 \\
7 / 16\end{array}$ \\
\hline
\end{tabular}

COMMENTS:

Pre 106k Failed Trailer Axle \#1

DATE:

$5 / 22 / 2012$

AXLE POSITION

BSAP

FREE STROKE

90 PSI

SPRING BRAKES

\begin{tabular}{|c|c|c|c|c|c|c|c|}
\hline 1L & & 1R & & $2 \mathrm{~L}$ & & $2 R$ & \\
\hline $21 / 4$ & & $21 / 4$ & & $\begin{array}{r}2 \\
1 / 4 \\
\end{array}$ & & $21 / 4$ & \\
\hline 2 1/2 & $1 / 4$ & $21 / 2$ & $1 / 4$ & $\begin{array}{r}2 \\
5 / 8 \\
\end{array}$ & $3 / 8$ & $25 / 8$ & $3 / 8$ \\
\hline $\begin{array}{ll}3 & 1 / 4\end{array}$ & 1 & $\begin{array}{ll}3 & 1 / 4 \\
\end{array}$ & 1 & $\begin{array}{r}3 \\
5 / 8 \\
\end{array}$ & $13 / 8$ & $\begin{array}{r}3 \\
11 / 16 \\
\end{array}$ & $\begin{array}{r}1 \\
7 / 16 \\
\end{array}$ \\
\hline & & & & $\begin{array}{r}3 \\
1 / 4 \\
\end{array}$ & $5 / 8$ & $31 / 4$ & $5 / 8$ \\
\hline
\end{tabular}

$3 \mathrm{~L}$

$3 \mathbf{R}$

\begin{tabular}{|c|c|c|}
\hline 4L & & \\
\hline $\begin{array}{r}6 \\
3 / 4\end{array}$ & & \\
\hline 7 & & \\
\hline $1 / 4$ & $1 / 2$ & \\
\hline 8 & 1 & \\
\hline $7 / 16$ & $11 / 16$ & \\
\hline 8 & $11 / 4$ & \\
\hline
\end{tabular}

\begin{tabular}{|c|c|c|c|c|c|}
\hline $4 R$ & & $5 \mathrm{~L}$ & & $5 R$ & \\
\hline $\begin{array}{r}0 \\
3 / 4\end{array}$ & & $\begin{array}{ll}6 & 3 / 4\end{array}$ & & $63 / 4$ & \\
\hline $\begin{array}{r}7 \\
5 / 16\end{array}$ & & & & & \\
\hline $\begin{array}{r}5 / 16 \\
8\end{array}$ & $9 / 16$ & $\begin{array}{ll}7 & 1 / 2 \\
\end{array}$ & $3 / 4$ & $73 / 8$ & $5 / 8$ \\
\hline $5 / 8$ & $17 / 8$ & $83 / 4$ & 2 & $81 / 2$ & $13 / 4$ \\
\hline $\begin{array}{r}8 \\
3 / 16\end{array}$ & $\begin{array}{r}1 \\
7 / 16\end{array}$ & $83 / 8$ & $15 / 8$ & $81 / 8$ & $13 / 8$ \\
\hline
\end{tabular}

COMMENTS:

Post 106k Failed Trailer Axle \#1

DATE:

$5 / 23 / 2012$ 


\begin{tabular}{|c|c|c|c|c|c|c|c|c|c|c|c|c|c|c|c|c|c|c|c|c|}
\hline AXLE POSITION & $1 \mathrm{~L}$ & & $1 R$ & & $2 \mathrm{~L}$ & & 2R & & $3 \mathrm{~L}$ & & 3R & & $4 \mathrm{~L}$ & & 4R & & $5 \mathrm{~L}$ & & $5 R$ & \\
\hline BSAP & $21 / 4$ & & $21 / 4$ & & $\begin{array}{r}2 \\
1 / 4 \\
\end{array}$ & & $21 / 4$ & & $21 / 4$ & & $21 / 4$ & & $\begin{array}{r}6 \\
3 / 4 \\
\end{array}$ & & $\begin{array}{r}6 \\
3 / 4 \\
\end{array}$ & & $\begin{array}{lll}6 & 3 / 4 \\
\end{array}$ & & $\begin{array}{lll}6 & 3 / 4 \\
\end{array}$ & \\
\hline FREE STROKE & $21 / 2$ & $1 / 4$ & $21 / 2$ & $1 / 4$ & $\begin{array}{r}2 \\
5 / 8 \\
\end{array}$ & $3 / 8$ & $25 / 8$ & $3 / 8$ & $21 / 2$ & $1 / 4$ & $25 / 8$ & $3 / 8$ & $\begin{array}{r}7 \\
1 / 4 \\
\end{array}$ & $1 / 2$ & \begin{tabular}{r|}
7 \\
$5 / 16$ \\
\end{tabular} & $9 / 16$ & $\begin{array}{ll}7 & 1 / 2 \\
\end{array}$ & $3 / 4$ & $73 / 8$ & $5 / 8$ \\
\hline $90 \mathrm{PSI}$ & $31 / 4$ & 1 & $31 / 4$ & 1 & $\begin{array}{r}3 \\
5 / 8 \\
\end{array}$ & $13 / 8$ & $\begin{array}{r}3 \\
11 / 16 \\
\end{array}$ & $\begin{array}{r}1 \\
7 / 16 \\
\end{array}$ & $41 / 8$ & $17 / 8$ & 4 & $13 / 4$ & $\begin{array}{r}8 \\
9 / 16 \\
\end{array}$ & $\begin{array}{r}1 \\
13 / 16 \\
\end{array}$ & $\begin{array}{r}8 \\
5 / 8 \\
\end{array}$ & $17 / 8$ & $83 / 4$ & 2 & $81 / 2$ & $13 / 4$ \\
\hline SPRING BRAKES & & & & & $\begin{array}{r}3 \\
1 / 8 \\
\end{array}$ & $1 / 2$ & $31 / 4$ & $5 / 8$ & & & & & 8 & $11 / 4$ & $\begin{array}{r}8 \\
3 / 16 \\
\end{array}$ & $\begin{array}{r}1 \\
7 / 16 \\
\end{array}$ & $83 / 8$ & $15 / 8$ & $81 / 8$ & $13 / 8$ \\
\hline
\end{tabular}

COMMENTS: $\quad$ Pre 106k Failed Trailer \#2

DATE:

$5 / 31 / 2012$

AXLE POSITION

BSAP

FREE STROKE

90 PSI

SPRING BRAKES

\begin{tabular}{|c|c|c|c|c|c|c|c|c|c|}
\hline 1L & & $1 R$ & & 2L & & $2 R$ & & 3L & \\
\hline $21 / 4$ & & $21 / 4$ & & $\begin{array}{r}2 \\
1 / 4 \\
\end{array}$ & & $21 / 4$ & & $21 / 4$ & \\
\hline $21 / 2$ & $1 / 4$ & $21 / 2$ & $1 / 4$ & $\begin{array}{r}2 \\
1 / 2\end{array}$ & $1 / 4$ & $21 / 2$ & $1 / 4$ & $24 / 7$ & $5 / 16$ \\
\hline \multirow[t]{2}{*}{$\begin{array}{ll}3 & 1 / 4\end{array}$} & 1 & $\begin{array}{ll}3 & 1 / 4\end{array}$ & 1 & $\begin{array}{r}3 \\
5 / 8 \\
\end{array}$ & $13 / 8$ & $35 / 8$ & $13 / 8$ & $33 / 4$ & $\begin{array}{ll}1 & 1 / 2\end{array}$ \\
\hline & & & & $\begin{array}{r}3 \\
1 / 8\end{array}$ & $5 / 8$ & $\begin{array}{ll}3 & 1 / 4\end{array}$ & $3 / 4$ & & \\
\hline
\end{tabular}

\begin{tabular}{|c|c|}
\hline $3 R$ & \\
\hline $21 / 4$ & \\
\hline $21 / 2$ & $1 / 4$ \\
\hline $\begin{array}{r}3 \\
11 / 16\end{array}$ & $\begin{array}{r}1 \\
7 / 16\end{array}$ \\
\hline & \\
\hline
\end{tabular}

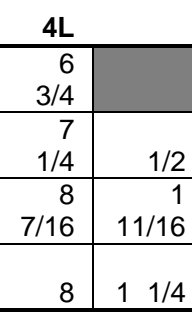

\begin{tabular}{|c|c|c|c|c|c|}
\hline 4R & & $5 \mathrm{~L}$ & & $5 R$ & \\
\hline $\begin{array}{r}6 \\
3 / 4\end{array}$ & & $63 / 4$ & & $63 / 4$ & \\
\hline $\begin{array}{r}7 \\
5 / 16\end{array}$ & $9 / 16$ & $7 \quad 1 / 2$ & $3 / 4$ & $73 / 8$ & $5 / 8$ \\
\hline $\begin{array}{r}8 \\
5 / 8\end{array}$ & $17 / 8$ & $83 / 4$ & 2 & $81 / 2$ & $13 / 4$ \\
\hline $\begin{array}{r}8 \\
3 / 16 \\
\end{array}$ & $\begin{array}{r}1 \\
7 / 16\end{array}$ & $83 / 8$ & $15 / 8$ & $85 / 8$ & $17 / 8$ \\
\hline
\end{tabular}

COMMENTS:

Pre 116k Full Function

DATE:

$5 / 31 / 2012$

AXLE POSITION

BSAP

FREE STROKE

90 PSI

SPRING BRAKES

\begin{tabular}{|c|c|c|c|c|c|c|c|}
\hline 1L & & $1 R$ & & 2L & & $2 R$ & \\
\hline $21 / 4$ & & $21 / 4$ & & $\begin{array}{r}2 \\
1 / 4\end{array}$ & & $\begin{array}{lll}2 & 1 / 4\end{array}$ & \\
\hline $21 / 2$ & $1 / 4$ & $21 / 2$ & $1 / 4$ & $\begin{array}{r}2 \\
5 / 8\end{array}$ & $3 / 8$ & $23 / 4$ & $1 / 2$ \\
\hline $\begin{array}{ll}3 & 1 / 4\end{array}$ & 1 & $\begin{array}{ll}3 & 1 / 4\end{array}$ & 1 & $\begin{array}{r}4 \\
1 / 8\end{array}$ & $17 / 8$ & $\begin{array}{lll}4 & 1 / 8\end{array}$ & $17 / 8$ \\
\hline & & & & $\begin{array}{r}3 \\
9 / 16\end{array}$ & $15 / 16$ & $\begin{array}{r}3 \\
9 / 16\end{array}$ & $13 / 16$ \\
\hline
\end{tabular}

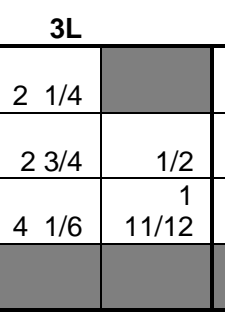

3R

\begin{tabular}{|c|c|c|c|c|c|c|c|c|c|}
\hline & & $4 \mathrm{~L}$ & & $4 R$ & & $J$ & & & \\
\hline $21 / 4$ & & $\begin{array}{r}6 \\
3 / 4 \\
\end{array}$ & & $\begin{array}{r}6 \\
3 / 4 \\
\end{array}$ & & $63 / 4$ & & $63 / 4$ & \\
\hline $23 / 4$ & $1 / 2$ & $\begin{array}{r}7 \\
1 / 4\end{array}$ & $1 / 2$ & $\begin{array}{r}2 \\
3 / 8\end{array}$ & $\begin{array}{r}-4 \\
3 / 8\end{array}$ & $\begin{array}{lll}7 & 1 / 2\end{array}$ & $3 / 4$ & $73 / 8$ & $5 / 8$ \\
\hline $\begin{array}{r}4 \\
1 / 16\end{array}$ & $\begin{array}{r}1 \\
13 / 16\end{array}$ & $\begin{array}{r}8 \\
1 / 2\end{array}$ & $13 / 4$ & $\begin{array}{r}8 \\
5 / 8\end{array}$ & $17 / 8$ & $83 / 4$ & 2 & $85 / 8$ & $17 / 8$ \\
\hline & & 8 & $11 / 4$ & $\begin{array}{r}8 \\
1 / 4\end{array}$ & $11 / 2$ & $81 / 4$ & $11 / 2$ & $81 / 8$ & $13 / 8$ \\
\hline
\end{tabular}

COMMENTS:

Pre 116k Failed Drive

DATE:

$6 / 2 / 2012$ 


\begin{tabular}{|c|c|c|c|c|c|c|c|c|c|c|c|c|c|c|c|c|c|c|c|c|}
\hline AXLE POSITION & $1 \mathrm{~L}$ & & 1R & & $2 \mathrm{~L}$ & & $2 \mathbf{R}$ & & $3 \mathrm{~L}$ & & 3R & & 4L & & 4R & & $5 \mathrm{~L}$ & & $5 R$ & \\
\hline BSAP & $21 / 4$ & & $21 / 4$ & & $\begin{array}{r}2 \\
1 / 4 \\
\end{array}$ & & $21 / 4$ & & $21 / 4$ & & $21 / 4$ & & $\begin{array}{r}6 \\
3 / 4 \\
\end{array}$ & & $\begin{array}{r}6 \\
3 / 4 \\
\end{array}$ & & $\begin{array}{ll}6 & 3 / 4 \\
\end{array}$ & & $\begin{array}{ll}6 & 3 / 4 \\
\end{array}$ & \\
\hline FREE STROKE & $21 / 2$ & $1 / 4$ & $21 / 2$ & $1 / 4$ & $\begin{array}{r}2 \\
1 / 2 \\
\end{array}$ & $1 / 4$ & $25 / 8$ & $3 / 8$ & $25 / 8$ & $3 / 8$ & $25 / 8$ & $3 / 8$ & $\begin{array}{r}7 \\
1 / 4 \\
\end{array}$ & $1 / 2$ & $\begin{array}{r}7 \\
3 / 8 \\
\end{array}$ & $5 / 8$ & $71 / 2$ & $3 / 4$ & $73 / 8$ & $5 / 8$ \\
\hline 90 PSI & $31 / 4$ & 0 & $31 / 4$ & 1 & 4 & $13 / 4$ & 4 & $13 / 4$ & 4 & $13 / 4$ & 4 & $13 / 4$ & $\begin{array}{r}8 \\
9 / 16 \\
\end{array}$ & $\begin{array}{r}1 \\
13 / 16 \\
\end{array}$ & $\begin{array}{r}8 \\
5 / 8 \\
\end{array}$ & $17 / 8$ & $83 / 4$ & 2 & $81 / 2$ & $13 / 4$ \\
\hline SPRING BRAKES & & & & & $\begin{array}{r}3 \\
1 / 2 \\
\end{array}$ & 1 & $31 / 2$ & $7 / 8$ & & & & & 8 & $11 / 4$ & $\begin{array}{r}8 \\
3 / 16 \\
\end{array}$ & $\begin{array}{r}1 \\
7 / 16 \\
\end{array}$ & $83 / 8$ & $15 / 8$ & $8 \quad 1 / 8$ & $13 / 8$ \\
\hline
\end{tabular}

COMMENTS: $\quad$ Pre 116k Failed Trailer

DATE:

$6 / 2 / 2012$

\begin{tabular}{|c|c|c|c|c|c|c|c|c|c|c|c|c|c|c|c|c|c|c|c|c|}
\hline AXLE POSITION & $1 \mathrm{~L}$ & & $1 R$ & & $2 \mathrm{~L}$ & & $2 R$ & & $3 \mathrm{~L}$ & & 3R & & $4 \mathrm{~L}$ & & 4R & & $5 \mathrm{~L}$ & & $5 R$ & \\
\hline BSAP & $21 / 4$ & & $21 / 4$ & & $\begin{array}{r}2 \\
1 / 4 \\
\end{array}$ & & $21 / 4$ & & $21 / 4$ & & $21 / 4$ & & $\begin{array}{r}6 \\
3 / 4 \\
\end{array}$ & & $\begin{array}{r}6 \\
3 / 4 \\
\end{array}$ & & $63 / 4$ & & $63 / 4$ & \\
\hline FREE STROKE & $23 / 8$ & $1 / 8$ & $23 / 8$ & $1 / 8$ & $\begin{array}{r}2 \\
1 / 2 \\
\end{array}$ & $1 / 4$ & $21 / 2$ & $1 / 4$ & $24 / 7$ & $5 / 16$ & $\begin{array}{r}2 \\
9 / 16 \\
\end{array}$ & $5 / 16$ & $\begin{array}{r}7 \\
1 / 4 \\
\end{array}$ & $1 / 2$ & $\begin{array}{r}7 \\
3 / 8 \\
\end{array}$ & $5 / 8$ & $\begin{array}{r}7 \\
9 / 16 \\
\end{array}$ & $13 / 16$ & $73 / 8$ & $5 / 8$ \\
\hline 90 PSI & $31 / 4$ & 0 & $31 / 4$ & 1 & $\begin{array}{r}3 \\
1 / 2 \\
\end{array}$ & $11 / 4$ & $31 / 2$ & $11 / 4$ & $33 / 4$ & $11 / 2$ & $33 / 4$ & $11 / 2$ & $\begin{array}{r}8 \\
7 / 16 \\
\end{array}$ & $\begin{array}{r}1 \\
11 / 16 \\
\end{array}$ & $\begin{array}{r}8 \\
5 / 8 \\
\end{array}$ & $17 / 8$ & $87 / 8$ & $21 / 8$ & $\begin{array}{r}8 \\
9 / 16 \\
\end{array}$ & $\begin{array}{r}1 \\
13 / 16 \\
\end{array}$ \\
\hline SPRING BRAKES & & & & & $\begin{array}{r}3 \\
1 / 4 \\
\end{array}$ & $3 / 4$ & $31 / 4$ & $3 / 4$ & & & & & $\begin{array}{r}8 \\
1 / 16 \\
\end{array}$ & $\begin{array}{r}1 \\
5 / 16 \\
\end{array}$ & $\begin{array}{r}8 \\
1 / 4 \\
\end{array}$ & $11 / 2$ & $83 / 8$ & $15 / 8$ & $81 / 8$ & $13 / 8$ \\
\hline
\end{tabular}

COMMENTS:

Post 116k Failed Trailer

DATE:

$6 / 4 / 2012$ 
APPENDIX C: PBBT RESULTS

Table C1. PBBT Scores - Fully Functioning Brakes, Before Test Set

\begin{tabular}{|c|c|c|c|c|c|c|c|c|c|c|c|c|}
\hline \multirow{2}{*}{$\begin{array}{c}\text { Load } \\
\text { Condition }\end{array}$} & \multirow{2}{*}{ Measure } & \multicolumn{2}{|c|}{ Axle 1} & \multicolumn{2}{|c|}{ Axle 2} & \multicolumn{2}{|c|}{ Axle 3} & \multicolumn{2}{|c|}{ Axle 4} & \multicolumn{2}{|c|}{ Axle 5} & \multirow{2}{*}{ Total } \\
\hline & & Left & Right & Left & Right & Left & Right & Left & Right & Left & Right & \\
\hline \multirow{3}{*}{$\begin{array}{l}\text { Control } \\
\text { Trailer }\end{array}$} & Brake Force (lb) & 4,658 & 4,114 & 4,078 & 5,733 & 4,141 & 5,305 & & & & & 28,029 \\
\hline & Weight (Ib) & 7,011 & 6,305 & 9,700 & 9,039 & 9,171 & 8,554 & & & & & 49,780 \\
\hline & Efficiency & $66.4 \%$ & $65.2 \%$ & $42.0 \%$ & $63.4 \%$ & $45.2 \%$ & $62.0 \%$ & & & & & $56.3 \%$ \\
\hline \multirow{3}{*}{$\begin{array}{l}60,000 \mathrm{lb} \\
\text { Load }\end{array}$} & Brake Force (lb) & 4,995 & 4,541 & 2,734 & 3,898 & 2,783 & 3,628 & 3,008 & 3,314 & 3,952 & 4,474 & 37,327 \\
\hline & Weight (lb) & 6,437 & 6,349 & 6,349 & 6,217 & 5,864 & 5,644 & 4,586 & 4,321 & 4,982 & 5,203 & 55,952 \\
\hline & Efficiency & $77.6 \%$ & $71.5 \%$ & $43.1 \%$ & $62.7 \%$ & $47.5 \%$ & $64.3 \%$ & $65.6 \%$ & $76.7 \%$ & $79.3 \%$ & $86.0 \%$ & $66.7 \%$ \\
\hline \multirow{3}{*}{$\begin{array}{l}80,000 \mathrm{lb} \\
\text { Balanced } \\
\text { Load }\end{array}$} & Brake Force (lb) & 5,580 & 3,831 & 6,245 & 3,408 & 5,261 & 3,476 & 5,859 & 4,761 & 6,196 & 6,434 & 51,051 \\
\hline & Weight (lb) & 6,614 & 5,997 & 8,686 & 7,584 & 8,466 & 7,231 & 8,069 & 6,923 & 7,628 & 7,496 & 74,694 \\
\hline & Efficiency & $84.4 \%$ & $63.9 \%$ & $71.9 \%$ & $44.9 \%$ & $62.1 \%$ & $48.1 \%$ & $72.6 \%$ & $68.8 \%$ & $81.2 \%$ & $85.8 \%$ & $68.3 \%$ \\
\hline \multirow{3}{*}{$\begin{array}{l}80,000 \mathrm{lb} \\
\text { Unbalanced } \\
\text { Load }\end{array}$} & Brake Force (lb) & 5,373 & 5,261 & 4,150 & 6,686 & 4,352 & 5,966 & 4,150 & 4,217 & 4,829 & 5,234 & 50,218 \\
\hline & Weight (lb) & 6,967 & 6,349 & 9,656 & 9,392 & 9,524 & 7,981 & 5,908 & 5,423 & 6,129 & 5,997 & 73,326 \\
\hline & Efficiency & $77.1 \%$ & $82.9 \%$ & $43.0 \%$ & $71.2 \%$ & $45.7 \%$ & $74.8 \%$ & $70.2 \%$ & $77.8 \%$ & $78.8 \%$ & $87.3 \%$ & $68.5 \%$ \\
\hline \multirow{3}{*}{$\begin{array}{l}91,000 \mathrm{lb} \\
\text { Load }\end{array}$} & Brake Force (lb) & 5,292 & 4,914 & 4,231 & 6,047 & 4,465 & 4,343 & 6,227 & 5,647 & 7,306 & 7,023 & 55,495 \\
\hline & Weight (lb) & 6,658 & 5,908 & 9,744 & 9,039 & 9,171 & 8,289 & 9,039 & 8,510 & 8,995 & 8,686 & 84,039 \\
\hline & Efficiency & $79.5 \%$ & $83.2 \%$ & $43.4 \%$ & $66.9 \%$ & $48.7 \%$ & $52.4 \%$ & $68.9 \%$ & $66.4 \%$ & $81.2 \%$ & $80.9 \%$ & $66.0 \%$ \\
\hline \multirow{3}{*}{$\begin{array}{l}97,000 \mathrm{lb} \\
\text { Load }\end{array}$} & Brake Force (Ib) & 4,955 & 5,634 & 3,759 & 4,011 & 3,781 & 5,270 & 7,428 & 8,044 & 7,104 & 7,365 & 57,351 \\
\hline & Weight (lb) & 6,437 & 5,820 & 8,642 & 7,981 & 8,201 & 7,099 & 12,125 & 10,759 & 12,302 & 11,464 & 90,830 \\
\hline & Efficiency & $77.0 \%$ & $96.8 \%$ & $43.5 \%$ & $50.3 \%$ & $46.1 \%$ & $74.2 \%$ & $61.3 \%$ & $74.8 \%$ & $57.7 \%$ & $64.2 \%$ & $63.1 \%$ \\
\hline \multirow{3}{*}{$\begin{array}{l}106,000 \mathrm{lb} \\
\text { Load }\end{array}$} & Brake Force (lb) & 5,499 & 5,148 & 6,564 & 5,211 & 5,126 & 6,573 & 6,965 & 7,572 & 7,019 & 7,401 & 63,078 \\
\hline & Weight (lb) & 7,011 & 6,526 & 11,288 & 10,803 & 11,023 & 9,833 & 11,111 & 10,670 & 11,067 & 10,891 & 100,223 \\
\hline & Efficiency & $78.4 \%$ & $78.9 \%$ & $58.2 \%$ & $48.2 \%$ & $46.5 \%$ & $66.8 \%$ & $62.7 \%$ & $71.0 \%$ & $63.4 \%$ & $68.0 \%$ & $62.9 \%$ \\
\hline \multirow{3}{*}{$\begin{array}{l}116,000 \mathrm{lb} \\
\text { Load }\end{array}$} & Brake Force (lb) & 5,625 & 5,553 & 5,521 & 7,167 & 5,993 & 6,191 & 6,875 & 7,117 & 6,735 & 6,875 & 63,652 \\
\hline & Weight (lb) & 7,319 & 6,217 & 12,522 & 11,640 & 11,817 & 10,538 & 12,787 & 11,552 & 13,095 & 12,037 & 109,524 \\
\hline & Efficiency & $76.9 \%$ & $89.3 \%$ & $44.1 \%$ & $61.6 \%$ & $50.7 \%$ & $58.7 \%$ & $53.8 \%$ & $61.6 \%$ & $51.4 \%$ & $57.1 \%$ & $58.1 \%$ \\
\hline
\end{tabular}


Table C2. PBBT Scores - Fully Functioning Brakes, After Test Set

\begin{tabular}{|c|c|c|c|c|c|c|c|c|c|c|c|c|}
\hline \multirow{2}{*}{$\begin{array}{c}\text { Load } \\
\text { Condition }\end{array}$} & \multirow{2}{*}{ Measure } & \multicolumn{2}{|c|}{ Axle 1} & \multicolumn{2}{|c|}{ Axle 2} & \multicolumn{2}{|c|}{ Axle 3} & \multicolumn{2}{|c|}{ Axle 4} & \multicolumn{2}{|c|}{ Axle 5} & \multirow{2}{*}{ Total } \\
\hline & & Left & Right & Left & Right & Left & Right & Left & Right & Left & Right & \\
\hline \multirow{3}{*}{$\begin{array}{l}\text { Control } \\
\text { Trailer }\end{array}$} & Brake Force (lb) & 4,334 & 4,321 & 3,844 & 4,285 & 4,096 & 5,283 & & & & & 26,163 \\
\hline & Weight (lb) & 6,878 & 6,217 & 9,656 & 9,039 & 9,304 & 8,422 & & & & & 49,516 \\
\hline & Efficiency & $63.0 \%$ & $69.5 \%$ & $39.8 \%$ & $47.4 \%$ & $44.0 \%$ & $62.7 \%$ & & & & & $52.8 \%$ \\
\hline \multirow{3}{*}{$\begin{array}{l}60,000 \mathrm{lb} \\
\text { Load }\end{array}$} & Brake Force (lb) & 5,072 & 4,896 & 2,608 & 4,645 & 2,747 & 4,384 & 2,945 & 3,183 & 3,984 & 4,276 & 38,740 \\
\hline & Weight (lb) & 6,614 & 5,732 & 5,908 & 5,820 & 5,908 & 5,115 & 4,409 & 4,012 & 4,894 & 4,806 & 53,218 \\
\hline & Efficiency & $76.7 \%$ & $85.4 \%$ & $44.1 \%$ & $79.8 \%$ & $46.5 \%$ & $85.7 \%$ & $66.8 \%$ & $79.3 \%$ & $81.4 \%$ & $89.0 \%$ & $72.8 \%$ \\
\hline \multirow{3}{*}{$\begin{array}{l}80,000 \mathrm{lb} \\
\text { Balanced } \\
\text { Load }\end{array}$} & Brake Force (lb) & 5,431 & 5,036 & 3,601 & 5,229 & 4,096 & 3,673 & 5,400 & 5,045 & 6,142 & 6,232 & 49,885 \\
\hline & Weight (lb) & 6,878 & 6,129 & 8,289 & 7,760 & 8,245 & 6,967 & 7,937 & 7,319 & 7,937 & 7,584 & 75,045 \\
\hline & Efficiency & $79.0 \%$ & $82.2 \%$ & $43.4 \%$ & $67.4 \%$ & $49.7 \%$ & $52.7 \%$ & $68.0 \%$ & $68.9 \%$ & $77.4 \%$ & $82.2 \%$ & $66.5 \%$ \\
\hline \multirow{3}{*}{$\begin{array}{l}80,000 \mathrm{lb} \\
\text { Unbalanced } \\
\text { Load }\end{array}$} & Brake Force (lb) & 5,045 & 4,348 & 4,321 & 5,764 & 4,253 & 4,303 & 4,110 & 4,172 & 5,135 & 5,220 & 46,671 \\
\hline & Weight (lb) & 6,967 & 6,041 & 9,744 & 9,348 & 9,568 & 8,245 & 6,173 & 5,556 & 6,129 & 5,952 & 73,723 \\
\hline & Efficiency & $72.4 \%$ & $72.0 \%$ & $44.3 \%$ & $61.7 \%$ & $44.5 \%$ & $52.2 \%$ & $66.6 \%$ & $75.1 \%$ & $83.8 \%$ & $87.7 \%$ & $63.3 \%$ \\
\hline \multirow{3}{*}{$\begin{array}{l}91,000 \mathrm{lb} \\
\text { Load }\end{array}$} & Brake Force (lb) & 5,004 & 5,022 & 5,697 & 4,123 & 4,505 & 5,085 & 5,517 & 6,079 & 6,704 & 6,987 & 54,723 \\
\hline & Weight (Ib) & 6,614 & 6,041 & 9,965 & 8,863 & 9,259 & 8,069 & 8,951 & 8,157 & 8,995 & 8,641 & 83,555 \\
\hline & Efficiency & $75.7 \%$ & $83.1 \%$ & $57.2 \%$ & $46.5 \%$ & $48.7 \%$ & $63.0 \%$ & $61.6 \%$ & $74.5 \%$ & $74.5 \%$ & $80.9 \%$ & $65.5 \%$ \\
\hline \multirow{3}{*}{$\begin{array}{l}97,000 \mathrm{lb} \\
\text { Load }\end{array}$} & Brake Force (lb) & 4,761 & 5,171 & 3,651 & 5,422 & 3,799 & 4,950 & 6,731 & 7,401 & 6,965 & 7,055 & 55,906 \\
\hline & Weight (lb) & 6,526 & 5,908 & 8,466 & 7,893 & 8,378 & 7,099 & 11,905 & 10,979 & 12,478 & 11,552 & 91,184 \\
\hline & Efficiency & $73.0 \%$ & $87.5 \%$ & $43.1 \%$ & $68.7 \%$ & $45.3 \%$ & $69.7 \%$ & $56.5 \%$ & $67.4 \%$ & $55.8 \%$ & $61.1 \%$ & $61.3 \%$ \\
\hline \multirow{3}{*}{$\begin{array}{l}106,000 \mathrm{lb} \\
\text { Load }\end{array}$} & Brake Force (lb) & 5,688 & 5,427 & 5,301 & 5,135 & 5,234 & 5,971 & 6,938 & 7,284 & 7,104 & 6,965 & 61,047 \\
\hline & Weight (lb) & 6,967 & 6,526 & 11,817 & 10,714 & 11,023 & 9,700 & 11,067 & 10,582 & 10,979 & 10,803 & 100,178 \\
\hline & Efficiency & $81.6 \%$ & $83.2 \%$ & $44.9 \%$ & $47.9 \%$ & $47.5 \%$ & $61.6 \%$ & $62.7 \%$ & $68.8 \%$ & $64.7 \%$ & $64.5 \%$ & $60.9 \%$ \\
\hline \multirow{3}{*}{$\begin{array}{l}116,000 \mathrm{lb} \\
\text { Load }\end{array}$} & Brake Force (lb) & 5,841 & 5,256 & 7,117 & 5,521 & 6,101 & 5,908 & 6,758 & 6,920 & 6,920 & 7,230 & 63,572 \\
\hline & Weight (lb) & 7,055 & 6,129 & 12,610 & 11,773 & 12,037 & 10,538 & 12,655 & 11,685 & 12,787 & 12,037 & 109,306 \\
\hline & Efficiency & $82.8 \%$ & $85.8 \%$ & $56.4 \%$ & $46.9 \%$ & $50.7 \%$ & $56.1 \%$ & $53.4 \%$ & $59.2 \%$ & $54.1 \%$ & $60.1 \%$ & $58.2 \%$ \\
\hline
\end{tabular}


Table C3. PBBT Scores - Disabled Front Drive Axle Brakes, Before Test Set

\begin{tabular}{|c|c|c|c|c|c|c|c|c|c|c|c|c|}
\hline \multirow{2}{*}{$\begin{array}{c}\text { Load } \\
\text { Condition }\end{array}$} & \multirow{2}{*}{ Measure } & \multicolumn{2}{|c|}{ Axle 1} & \multicolumn{2}{|c|}{ Axle 2} & \multicolumn{2}{|c|}{ Axle 3} & \multicolumn{2}{|c|}{ Axle 4} & \multicolumn{2}{|c|}{ Axle 5} & \multirow{2}{*}{ Total } \\
\hline & & Left & Right & Left & Right & Left & Right & Left & Right & Left & Right & \\
\hline Control Trailer & $\begin{array}{l}\text { Brake Force (lb) } \\
\text { Weight (lb) } \\
\text { Efficiency }\end{array}$ & & & & & & & & & & & \\
\hline \multirow{3}{*}{ 60,000 lb Load } & Brake Force (lb) & 5,103 & 4,743 & 0 & 4 & 2,878 & 3,862 & 3,075 & 3,084 & 4,002 & 4,060 & 30,811 \\
\hline & Weight (lb) & 6,570 & 5,952 & 6,047 & 5,864 & 5,997 & 5,335 & 4,630 & 3,836 & 5,027 & 4,806 & 54,064 \\
\hline & Efficiency & $77.7 \%$ & $79.7 \%$ & $0.0 \%$ & $0.1 \%$ & $48.0 \%$ & $72.4 \%$ & $66.4 \%$ & $80.4 \%$ & $79.6 \%$ & $84.5 \%$ & $57.0 \%$ \\
\hline \multirow{3}{*}{$\begin{array}{l}80,000 \mathrm{lb} \\
\text { Balanced Load }\end{array}$} & Brake Force (lb) & 5,297 & 4,276 & 9 & 18 & 3,849 & 4,699 & 5,472 & 5,081 & 6,007 & 6,137 & 40,845 \\
\hline & Weight (lb) & 6,702 & 5,732 & 8,378 & 7,672 & 8,025 & 7,055 & 7,716 & 7,143 & 7,981 & 7,496 & 73,900 \\
\hline & Efficiency & $79.0 \%$ & $74.6 \%$ & $0.1 \%$ & $0.2 \%$ & $48.0 \%$ & $66.6 \%$ & $70.9 \%$ & $71.1 \%$ & $75.3 \%$ & $81.9 \%$ & $55.3 \%$ \\
\hline \multirow{3}{*}{$\begin{array}{l}80,000 \mathrm{lb} \\
\text { Unbalanced } \\
\text { Load }\end{array}$} & Brake Force (lb) & 5,328 & 5,198 & 36 & 18 & 4,321 & 5,948 & 3,772 & 4,550 & 4,806 & 5,400 & 39,377 \\
\hline & Weight (lb) & 6,834 & 6,129 & 9,789 & 9,127 & 9,348 & 8,289 & 6,129 & 5,556 & 6,261 & 5,864 & 73,326 \\
\hline & Efficiency & $78.0 \%$ & $84.8 \%$ & $0.4 \%$ & $0.2 \%$ & $46.2 \%$ & $71.8 \%$ & $61.5 \%$ & $81.9 \%$ & $76.8 \%$ & $92.1 \%$ & $53.7 \%$ \\
\hline \multirow{3}{*}{ 91,000 lb Load } & Brake Force (lb) & 5,112 & 5,081 & 9 & 18 & 4,379 & 5,899 & 5,517 & 6,434 & 6,771 & 7,135 & 46,355 \\
\hline & Weight (lb) & 6,570 & 5,997 & 9,436 & 8,995 & 9,436 & 8,025 & 9,039 & 8,333 & 9,215 & 8,863 & 83,909 \\
\hline & Efficiency & $77.8 \%$ & $84.7 \%$ & $0.1 \%$ & $0.2 \%$ & $46.4 \%$ & $73.5 \%$ & $61.0 \%$ & $77.2 \%$ & $73.5 \%$ & $80.5 \%$ & $55.2 \%$ \\
\hline \multirow{3}{*}{ 97,000 lb Load } & Brake Force (lb) & 4,973 & 4,910 & 9 & 22 & 3,997 & 4,797 & 7,014 & 7,522 & 6,362 & 6,623 & 46,229 \\
\hline & Weight (lb) & 6,702 & 5,776 & 8,466 & 7,937 & 8,554 & 7,187 & 11,817 & 10,803 & 12,478 & 11,508 & 91,228 \\
\hline & Efficiency & $74.2 \%$ & $85.0 \%$ & $0.1 \%$ & $0.3 \%$ & $46.7 \%$ & $66.7 \%$ & $59.4 \%$ & $69.6 \%$ & $51.0 \%$ & $57.6 \%$ & $50.7 \%$ \\
\hline \multirow{3}{*}{ 106,000 lb Load } & Brake Force (lb) & 5,283 & 5,153 & 22 & 22 & 5,436 & 5,998 & 6,618 & 6,915 & 6,893 & 7,158 & 49,498 \\
\hline & Weight (lb) & 6,967 & 6,570 & 11,729 & 10,626 & 11,420 & 9,700 & 10,979 & 10,318 & 11,111 & 10,538 & 99,958 \\
\hline & Efficiency & $75.8 \%$ & $78.4 \%$ & $0.2 \%$ & $0.2 \%$ & $47.6 \%$ & $61.8 \%$ & $60.3 \%$ & $67.0 \%$ & $62.0 \%$ & $67.9 \%$ & $49.5 \%$ \\
\hline \multirow{3}{*}{$116,000 \mathrm{lb}$ Load } & Brake Force (lb) & 5,661 & 5,530 & 4 & 22 & 7,284 & 5,076 & 7,365 & 7,405 & 6,884 & 7,347 & 52,578 \\
\hline & Weight (lb) & 6,746 & 6,437 & 12,478 & 11,552 & 12,037 & 10,582 & 12,699 & 11,685 & 12,919 & 11,993 & 109,128 \\
\hline & Efficiency & $83.9 \%$ & $85.9 \%$ & $0.0 \%$ & $0.2 \%$ & $60.5 \%$ & $48.0 \%$ & $58.0 \%$ & $63.4 \%$ & $53.3 \%$ & $61.3 \%$ & $48.2 \%$ \\
\hline
\end{tabular}


Table C4. PBBT Scores - Disabled Front Drive Axle Brakes, After Test Set

\begin{tabular}{|c|c|c|c|c|c|c|c|c|c|c|c|c|}
\hline \multirow{2}{*}{$\begin{array}{c}\text { Load } \\
\text { Condition }\end{array}$} & \multirow{2}{*}{ Measure } & \multicolumn{2}{|c|}{ Axle 1} & \multicolumn{2}{|c|}{ Axle 2} & \multicolumn{2}{|c|}{ Axle 3} & \multicolumn{2}{|c|}{ Axle 4} & \multicolumn{2}{|c|}{ Axle 5} & \multirow{2}{*}{ Total } \\
\hline & & Left & Right & Left & Right & Left & Right & Left & Right & Left & Right & \\
\hline Control Trailer & $\begin{array}{l}\text { Brake Force (lb) } \\
\text { Weight (lb) } \\
\text { Efficiency }\end{array}$ & & & & & & & & & & & \\
\hline \multirow{3}{*}{ 60,000 lb Load } & Brake Force (lb) & 4,699 & 4,096 & 0 & 9 & 3,039 & 3,471 & 2,958 & 3,404 & 3,939 & 4,555 & 30,170 \\
\hline & Weight (lb) & 6,570 & 5,688 & 6,614 & 5,688 & 6,085 & 5,291 & 4,321 & 3,748 & 4,938 & 4,850 & 53,793 \\
\hline & Efficiency & $71.5 \%$ & $72.0 \%$ & $0.0 \%$ & $0.2 \%$ & $49.9 \%$ & $65.6 \%$ & $68.5 \%$ & $90.8 \%$ & $79.8 \%$ & $93.9 \%$ & $56.1 \%$ \\
\hline \multirow{3}{*}{$\begin{array}{l}80,000 \mathrm{lb} \\
\text { Balanced Load }\end{array}$} & Brake Force (lb) & 5,332 & 5,099 & 4 & 13 & 4,932 & 3,565 & 5,647 & 5,099 & 6,124 & 5,975 & 41,790 \\
\hline & Weight (Ib) & 6,349 & 6,217 & 8,510 & 7,628 & 8,025 & 7,011 & 7,760 & 7,231 & 7,937 & 7,452 & 74,120 \\
\hline & Efficiency & $84.0 \%$ & $82.0 \%$ & $0.0 \%$ & $0.2 \%$ & $61.5 \%$ & $50.8 \%$ & $72.8 \%$ & $70.5 \%$ & $77.2 \%$ & $80.2 \%$ & $56.4 \%$ \\
\hline \multirow{3}{*}{$\begin{array}{l}80,000 \mathrm{lb} \\
\text { Unbalanced } \\
\text { Load }\end{array}$} & Brake Force (lb) & 5,584 & 5,036 & 31 & 22 & 4,492 & 5,733 & 4,132 & 4,101 & 4,887 & 5,018 & 39,036 \\
\hline & Weight (lb) & 7,055 & 6,129 & 9,700 & 8,951 & 9,436 & 7,893 & 6,173 & 5,688 & 6,041 & 5,776 & 72,842 \\
\hline & Efficiency & $79.1 \%$ & $82.2 \%$ & $0.3 \%$ & $0.2 \%$ & $47.6 \%$ & $72.6 \%$ & $66.9 \%$ & $72.1 \%$ & $80.9 \%$ & $86.9 \%$ & $53.6 \%$ \\
\hline \multirow{3}{*}{ 91,000 lb Load } & Brake Force (lb) & 4,905 & 4,613 & 9 & 13 & 4,406 & 5,625 & 5,728 & 7,180 & 6,668 & 7,518 & 46,665 \\
\hline & Weight (lb) & 6,570 & 6,129 & 9,965 & 8,951 & 9,171 & 8,201 & 8,863 & 8,598 & 8,907 & 8,730 & 84,085 \\
\hline & Efficiency & $74.7 \%$ & $75.3 \%$ & $0.1 \%$ & $0.1 \%$ & $48.0 \%$ & $68.6 \%$ & $64.6 \%$ & $83.5 \%$ & $74.9 \%$ & $86.1 \%$ & $55.5 \%$ \\
\hline \multirow{3}{*}{ 97,000 lb Load } & Brake Force (lb) & 5,238 & 4,685 & 4 & 13 & 5,054 & 3,624 & 7,230 & 7,140 & 6,911 & 7,131 & 47,030 \\
\hline & Weight (lb) & 6,658 & 5,908 & 8,818 & 7,716 & 8,642 & 7,143 & 11,905 & 10,714 & 12,390 & 11,155 & 91,049 \\
\hline & Efficiency & $78.7 \%$ & $79.3 \%$ & $0.0 \%$ & $0.2 \%$ & $58.5 \%$ & $50.7 \%$ & $60.7 \%$ & $66.6 \%$ & $55.8 \%$ & $63.9 \%$ & $51.7 \%$ \\
\hline \multirow{3}{*}{106,000 lb Load } & Brake Force (lb) & 5,463 & 5,827 & 9 & 13 & 5,207 & 6,488 & 6,753 & 7,032 & 6,794 & 6,596 & 50,182 \\
\hline & Weight (lb) & 6,923 & 6,526 & 11,155 & 10,847 & 10,847 & 9,744 & 10,979 & 10,229 & 11,376 & 10,670 & 99,296 \\
\hline & Efficiency & $78.9 \%$ & $89.3 \%$ & $0.1 \%$ & $0.1 \%$ & $48.0 \%$ & $66.6 \%$ & $61.5 \%$ & $68.7 \%$ & $59.7 \%$ & $61.8 \%$ & $50.5 \%$ \\
\hline \multirow{3}{*}{116,000 lb Load } & Brake Force (lb) & 5,769 & 4,937 & 13 & 13 & 6,151 & 6,007 & 6,659 & 7,063 & 6,843 & 7,149 & 50,604 \\
\hline & Weight (lb) & 7,011 & 6,261 & 12,522 & 11,640 & 12,316 & 10,494 & 12,699 & 11,332 & 12,787 & 11,993 & 109,055 \\
\hline & Efficiency & $82.3 \%$ & $78.9 \%$ & $0.1 \%$ & $0.1 \%$ & $49.9 \%$ & $57.2 \%$ & $52.4 \%$ & $62.3 \%$ & $53.5 \%$ & $59.6 \%$ & $46.4 \%$ \\
\hline
\end{tabular}


Table C5. PBBT Scores - Disabled Rear Trailer Axle Brakes, Before Test Set

\begin{tabular}{|c|c|c|c|c|c|c|c|c|c|c|c|c|}
\hline \multirow{2}{*}{$\begin{array}{c}\text { Load } \\
\text { Condition }\end{array}$} & \multirow{2}{*}{ Measure } & \multicolumn{2}{|c|}{ Axle 1} & \multicolumn{2}{|c|}{ Axle 2} & \multicolumn{2}{|c|}{ Axle 3} & \multicolumn{2}{|c|}{ Axle 4} & \multicolumn{2}{|c|}{ Axle 5} & \multirow{2}{*}{ Total } \\
\hline & & Left & Right & Left & Right & Left & Right & Left & Right & Left & Right & \\
\hline Control Trailer & $\begin{array}{l}\text { Brake Force (lb) } \\
\text { Weight (lb) } \\
\text { Efficiency }\end{array}$ & & & & & & & & & & & \\
\hline \multirow{3}{*}{ 60,000 lb Load } & Brake Force (lb) & 4,734 & 3,898 & 4,253 & 2,432 & 3,035 & 3,516 & 2,707 & 3,228 & 4 & 9 & 27,816 \\
\hline & Weight (lb) & 6,570 & 5,688 & 6,526 & 5,776 & 6,129 & 5,423 & 4,233 & 3,836 & 5,159 & 5,029 & 54,369 \\
\hline & Efficiency & $72.1 \%$ & $68.5 \%$ & $65.2 \%$ & $42.1 \%$ & $49.5 \%$ & $64.8 \%$ & $63.9 \%$ & $84.2 \%$ & $0.1 \%$ & $0.2 \%$ & $51.2 \%$ \\
\hline \multirow{3}{*}{$\begin{array}{l}80,000 \mathrm{lb} \\
\text { Balanced Load }\end{array}$} & Brake Force (lb) & 4,793 & 4,815 & 3,570 & 5,377 & 3,993 & 4,406 & 4,577 & 4,402 & 9 & 13 & 35,955 \\
\hline & Weight (Ib) & 6,129 & 5,864 & 8,289 & 7,628 & 8,069 & 7,011 & 7,716 & 7,011 & 7,716 & 7,231 & 72,664 \\
\hline & Efficiency & $78.2 \%$ & $82.1 \%$ & $43.1 \%$ & $70.5 \%$ & $49.5 \%$ & $62.8 \%$ & $59.3 \%$ & $62.8 \%$ & $0.1 \%$ & $0.2 \%$ & $49.5 \%$ \\
\hline \multirow{3}{*}{$\begin{array}{l}80,000 \mathrm{lb} \\
\text { Unbalanced } \\
\text { Load }\end{array}$} & Brake Force (lb) & 5,157 & 4,833 & 4,074 & 6,695 & 4,357 & 5,935 & 3,727 & 4,020 & 4 & 9 & 38,811 \\
\hline & Weight (lb) & 6,702 & 6,305 & 9,700 & 9,039 & 9,392 & 8,245 & 6,129 & 5,423 & 6,173 & 5,776 & 72,884 \\
\hline & Efficiency & $76.9 \%$ & $76.7 \%$ & $42.0 \%$ & $74.1 \%$ & $46.4 \%$ & $72.0 \%$ & $60.8 \%$ & $74.1 \%$ & $0.1 \%$ & $0.2 \%$ & $53.3 \%$ \\
\hline \multirow{3}{*}{91,000 lb Load } & Brake Force (lb) & 4,896 & 4,213 & 4,213 & 6,524 & 4,303 & 5,827 & 5,373 & 6,843 & 13 & 13 & 42,218 \\
\hline & Weight (Ib) & 6,702 & 6,041 & 9,833 & 8,774 & 9,524 & 7,937 & 8,995 & 8,245 & 8,992 & 8,510 & 83,553 \\
\hline & Efficiency & $73.1 \%$ & $69.7 \%$ & $42.8 \%$ & $74.4 \%$ & $45.2 \%$ & $73.4 \%$ & $59.7 \%$ & $83.0 \%$ & $0.1 \%$ & $0.2 \%$ & $50.5 \%$ \\
\hline \multirow{3}{*}{ 97,000 lb Load } & Brake Force (lb) & 5,247 & 5,323 & 4,690 & 7,248 & 5,710 & 5,072 & 5,998 & 7,068 & 40 & 18 & 46,414 \\
\hline & Weight (lb) & 6,967 & 6,261 & 11,244 & 10,803 & 11,111 & 9,744 & 10,935 & 10,229 & 11,067 & 10,406 & 98,767 \\
\hline & Efficiency & $75.3 \%$ & $85.0 \%$ & $41.7 \%$ & $67.1 \%$ & $51.4 \%$ & $52.1 \%$ & $54.9 \%$ & $69.1 \%$ & $0.4 \%$ & $0.2 \%$ & $47.0 \%$ \\
\hline \multirow{3}{*}{106,000 lb Load } & Brake Force (lb) & 5,238 & 5,512 & 5,022 & 6,731 & 6,313 & 5,099 & 6,771 & 6,074 & 9 & 18 & 46,787 \\
\hline & Weight (Ib) & 6,658 & 6,393 & 11,464 & 10,670 & 10,935 & 9,392 & 11,155 & 10,009 & 11,023 & 10,274 & 97,973 \\
\hline & Efficiency & $78.7 \%$ & $86.2 \%$ & $43.8 \%$ & $63.1 \%$ & $57.7 \%$ & $54.3 \%$ & $60.7 \%$ & $60.7 \%$ & $0.1 \%$ & $0.2 \%$ & $47.8 \%$ \\
\hline \multirow{3}{*}{116,000 lb Load } & Brake Force (lb) & 5,647 & 4,919 & 7,365 & 5,350 & 6,295 & 5,926 & 6,510 & 6,794 & 18 & 18 & 48,842 \\
\hline & Weight (Ib) & 7,011 & 6,217 & 12,787 & 11,376 & 11,993 & 10,626 & 12,655 & 11,508 & 12,699 & 11,905 & 108,777 \\
\hline & Efficiency & $80.5 \%$ & $79.1 \%$ & $57.6 \%$ & $47.0 \%$ & $52.5 \%$ & $55.8 \%$ & $51.4 \%$ & $59.0 \%$ & $0.1 \%$ & $0.2 \%$ & $44.9 \%$ \\
\hline
\end{tabular}


Table C6. PBBT Scores - Disabled Rear Trailer Axle Brakes, After Test Set

\begin{tabular}{|c|c|c|c|c|c|c|c|c|c|c|c|c|}
\hline \multirow{2}{*}{$\begin{array}{c}\text { Load } \\
\text { Condition }\end{array}$} & \multirow{2}{*}{ Measure } & \multicolumn{2}{|c|}{ Axle 1} & \multicolumn{2}{|c|}{ Axle 2} & \multicolumn{2}{|c|}{ Axle 3} & \multicolumn{2}{|c|}{ Axle 4} & \multicolumn{2}{|c|}{ Axle 5} & \multirow{2}{*}{ Total } \\
\hline & & Left & Right & Left & Right & Left & Right & Left & Right & Left & Right & \\
\hline Control Trailer & $\begin{array}{l}\text { Brake Force (lb) } \\
\text { Weight (lb) } \\
\text { Efficiency }\end{array}$ & & & & & & & & & & & \\
\hline \multirow{3}{*}{ 60,000 lb Load } & Brake Force (lb) & 4,910 & 4,145 & 2,693 & 3,979 & 2,828 & 3,637 & 2,887 & 3,300 & 4 & 9 & 28,392 \\
\hline & Weight (lb) & 6,393 & 5,688 & 6,041 & 5,776 & 5,908 & 5,247 & 4,674 & 3,968 & 4,762 & 4,938 & 53,395 \\
\hline & Efficiency & $76.8 \%$ & $72.9 \%$ & $44.6 \%$ & $68.9 \%$ & $47.9 \%$ & $69.3 \%$ & $61.8 \%$ & $83.2 \%$ & $0.1 \%$ & $0.2 \%$ & $53.2 \%$ \\
\hline \multirow{3}{*}{$\begin{array}{l}80,000 \mathrm{lb} \\
\text { Balanced Load }\end{array}$} & Brake Force (lb) & 4,609 & 4,519 & 5,458 & 3,489 & 5,004 & 3,476 & 4,842 & 4,357 & 0 & 13 & 35,767 \\
\hline & Weight (lb) & 6,437 & 6,217 & 8,289 & 7,672 & 7,981 & 7,231 & 7,540 & 7,231 & 7,496 & 7,469 & 73,563 \\
\hline & Efficiency & $71.6 \%$ & $72.7 \%$ & $65.8 \%$ & $45.5 \%$ & $62.7 \%$ & $48.1 \%$ & $64.2 \%$ & $60.3 \%$ & $0.0 \%$ & $0.2 \%$ & $48.6 \%$ \\
\hline \multirow{3}{*}{$\begin{array}{l}80,000 \mathrm{lb} \\
\text { Unbalanced } \\
\text { Load }\end{array}$} & Brake Force (lb) & 4,874 & 5,085 & 4,213 & 5,868 & 4,582 & 5,256 & 3,574 & 3,588 & 4 & 9 & 37,053 \\
\hline & Weight (lb) & 6,923 & 5,997 & 9,700 & 9,171 & 9,567 & 8,289 & 5,820 & 5,247 & 6,173 & 5,820 & 72,707 \\
\hline & Efficiency & $70.4 \%$ & $84.8 \%$ & $43.4 \%$ & $64.0 \%$ & $47.9 \%$ & $63.4 \%$ & $61.4 \%$ & $68.4 \%$ & $0.1 \%$ & $0.2 \%$ & $51.0 \%$ \\
\hline \multirow{3}{*}{91,000 lb Load } & Brake Force (lb) & 4,784 & 4,690 & 5,485 & 4,253 & 4,465 & 4,937 & 5,117 & 5,454 & 4 & 13 & 39,202 \\
\hline & Weight (lb) & 7,011 & 5,864 & 9,789 & 9,039 & 9,567 & 8,157 & 8,995 & 8,378 & 9,127 & 8,642 & 84,569 \\
\hline & Efficiency & $68.2 \%$ & $80.0 \%$ & $56.0 \%$ & $47.1 \%$ & $46.7 \%$ & $60.5 \%$ & $56.9 \%$ & $65.1 \%$ & $0.0 \%$ & $0.2 \%$ & $46.4 \%$ \\
\hline \multirow{3}{*}{97,000 lb Load } & Brake Force (lb) & 5,679 & 4,523 & 5,081 & 6,061 & 2,887 & 5,193 & 6,618 & 5,984 & 0 & 18 & 42,044 \\
\hline & Weight (lb) & 6,834 & 6,526 & 11,508 & 10,759 & 11,376 & 9,700 & 11,288 & 10,318 & 11,420 & 10,582 & 100,311 \\
\hline & Efficiency & $83.1 \%$ & $69.3 \%$ & $44.2 \%$ & $56.3 \%$ & $25.4 \%$ & $53.5 \%$ & $58.6 \%$ & $58.0 \%$ & $0.0 \%$ & $0.2 \%$ & $41.9 \%$ \\
\hline \multirow{3}{*}{106,000 lb Load } & Brake Force (lb) & 5,117 & 5,031 & 6,807 & 4,869 & 5,476 & 4,685 & 6,119 & 6,038 & 9 & 18 & 44,169 \\
\hline & Weight (lb) & 7,011 & 6,305 & 11,685 & 10,582 & 11,067 & 9,568 & 10,979 & 10,009 & 11,111 & 10,494 & 98,811 \\
\hline & Efficiency & $73.0 \%$ & $79.8 \%$ & $58.3 \%$ & $46.0 \%$ & $49.5 \%$ & $49.0 \%$ & $55.7 \%$ & $60.3 \%$ & $0.1 \%$ & $0.2 \%$ & $44.7 \%$ \\
\hline \multirow{3}{*}{116,000 lb Load } & Brake Force (lb) & 5,508 & 4,856 & 7,149 & 5,544 & 5,899 & 6,569 & 6,843 & 6,915 & 13 & 31 & 49,327 \\
\hline & Weight (lb) & 7,187 & 6,393 & 12,610 & 11,729 & 11,685 & 10,406 & 12,919 & 11,508 & 12,787 & 12,037 & 109,261 \\
\hline & Efficiency & $76.6 \%$ & $76.0 \%$ & $56.7 \%$ & $47.3 \%$ & $50.5 \%$ & $63.1 \%$ & $53.0 \%$ & $60.1 \%$ & $0.1 \%$ & $0.3 \%$ & $45.1 \%$ \\
\hline
\end{tabular}




\begin{tabular}{|c|c|c|c|}
\hline \multicolumn{4}{|c|}{ HOVBT Combination Vehicle Final Report Revision Log } \\
\hline $\begin{array}{c}\text { Revision } \\
\text { Number }\end{array}$ & Description of Change & Editor(s) & $\begin{array}{c}\text { Change Effective } \\
\text { Date }\end{array}$ \\
\hline 0 & Initial draft & MBL & 26 Aug 2013 \\
\hline 1 & Incorporated changes from GC, OF & MBL & 20 Sep 2013 \\
\hline 2 & Marked edits & SAM & 23 Sep 2013 \\
\hline
\end{tabular}

